\title{
Intraday industry-specific spillover effect in European Equity Markets
}

\author{
Cesario MATEUS \\ University of Greenwich Business School \\ London, United Kingdom \\ c.mateus@greenwich.ac.uk \\ Raju CHINTHALAPATI \\ University of Greenwich Business School \\ London, United Kingdom \\ Irina B. MATEUS \\ University of Greenwich Business School \\ London, United Kingdom
}

\begin{abstract}
This paper investigates the existence of financial contagion between the US and ten European stock markets. Using intraday minute-per-minute data of a large set of 374 equities from three different industries, over the period from January to June 2011, we investigate the impact of increased volatility in the US on the inter-country industry-level spillover effect. Self-built industry indices are used, which allows the implementation of the same index methodology across different markets. We first show that the spillover of asset price volatility from the US to European markets does exist; the greatest spike in the volatility in the target markets is observed in the first minute, and is absorbed in the first five minutes after the volatility increase. Second, we can state that euro-denominated markets amplify the spillover effect of volatility from the US market. Third, we provide evidence of the industry heterogeneity of the spillover effects, and claim that an analysis of financial contagion across different industries is desirable, using industry indices instead of global market indices.
\end{abstract}

\section{JEL Classification: G1, G15}

Keywords: Financial Contagion, Consumer Confidence Index, European Stock markets, Spillover Effect 


\section{Introduction}

In August 2011, Wall Street experienced one of the most volatile weeks in its history. This wild volatility spread rapidly across Europe and Asia, due to the high level of linkages and interactions between stock markets around the world. Financial contagion is not a new phenomenon, but its incidence has been growing over time. Recent advances in computer technologies and information processing have increased integration between different markets by responding quickly to news, shocks and market announcements, and have accelerated the transmission of information and consumer sentiment spillover around the world.

A significant strand of academic literature has analyzed the spillover effect across markets by using daily data, which does not properly account for how quickly interconnected trading venues spread information, and how this is reflected in increased volatility. Recent academic papers have examined short-run information transmission based on five-minute frequency data. The results show signs of very strong interdependence between different stock markets; however, they do not reveal any indication of contagion. Jung and Maderitsch (2014) investigated non-overlapping realized volatility transmission between stock markets in Hong Kong, Europe and the United States for the 2000-2011 period, using five-minute sampled stock index data. The paper documents sudden shifts in volatility transmission driven by market co-movements without a sign of contagion. In turn, Hussain (2011) analyzed lagged trading activity using concurrent data from the German and British equity markets, and highlighted the impact of trading volume on stock volatility. However, the research was unable to measure the information transmission mechanism between stock markets. Several papers, including those of Égert and Kočenda (2007) and Wu and Zhang (2005), emphasised the signs of short-term spillover effects, both in terms of stock returns and stock price volatility. Evans (2011) examined intraday jumps associated with US macroeconomic news announcements, and also observed dramatic reactions of financial markets to economic fundamentals in the very short term.

Taking into the consideration the previous literature, the aim of this paper is to provide more highlights on volatility spillover effects between the US market and ten European markets (Athens, Brussels, Paris, Frankfurt, London, Madrid, Dublin, Milan, Stockholm, and Zurich). Our major target is to shed new light on the industry heterogeneity of the spillover effects, and the speed and patterns of information transmission across 
different industries. Following the recent studies on industry-specific volatility (Wang, 2010), and financial risk contagion and tail risk spillover between financials and non-financials (Grammatikos and Vermeulen, 2012; Chiu et al., 2014), we claim that volatility transmission between stock markets may differ across industries. In contrast to the previous studies, which have tended to use global market indices for the analysis of the whole market movements, the main contribution of this paper is the proposition of a novel approach featuring a unique construction methodology for industry indices. We argue that the use of global market indices is not desirable for the analysis of inter-market industry spillover effects, since the weight of each sector in the indices composition between countries is different. The self-built industry indices proposed in this paper will lead to a more accurate test of the industry-level spillover effect, and will allow the implementation of the same index methodology across different markets.

According to the SEC report from March 2014, high-frequency trading exceeded 50 percent of total volume in US-listed equities, and was called "a dominant component of the current market structure which is likely to affect nearly all aspects of its performance." Therefore, in this paper we estimate a spillover effect between the US and European markets in an even shorter term than previously analyzed, using minute-per-minute intraday data for a total of 374 equities, from January to June 2011.

As the time reference point for the analysis, we use the US consumer confidence announcement. The consumer confidence index provides information on present and expected economic activity, and is based on five major questions about current and expected business conditions, job availability and respondents' expected income. As a result, it helps to track labour market conditions, the growth in payroll employment, and it represents information about future household spending. The existing literature states that consumer confidence is highly correlated with real economic activity (Jansen and Nahuis, 2003; Batchelor and Dua, 1998; Chen, 2011); that it is a leading indicator in many macroeconomic forecasts (Oest and Franses, 2008; Gelper at al., 2007); and that it can be viewed as a key determinant of near-term economic growth (Howrey, 2001; Ludvigson, 2004; Evans and Chamberlain, 2014). Several studies, such as those of Weder (1998) and Chen (2011), suggest that consumer confidence is one of the transmission channels through which consumer sentiment spreads between markets and may cause economic fluctuations. Otoo (1999) and Jansen and Nahuis (2003) provide evidence that stock returns and changes in 
consumer sentiment are generally positively correlated. Following the above, we claim that the announcement of the consumer confidence index will provoke an increase in volatility with a spread between markets, and that it will make an impact on the decision-making process in the three industries analyzed: Financials, Healthcare, and Industrials. Thus, we choose the consumer confidence index among the other announcements, as an example and a good reference point for the investigation of volatility spillover. ${ }^{1}$

Since we state that the recent advanced technologies have accelerated the speed of information processing and have considerably shortened the time of information transmission between markets, we claim that only the analysis of overlapping trading hours can reveal accurate information about market dynamics. This approach is consistent with that of Grammig, Melvin and Schlag (2005), who studied where price discovery occurs and how stock prices adjust to an exchange rate shock, using cross-listed prices from New York (NYSE) and Frankfurt (XETRA) during overlapping trading hours.

To calculate asset volatility we apply Garman and Klass's (1980) volatility estimator, which differs from the classical volatility estimator that cannot reflect fluctuations within a period. The Garman-Klass estimator is well known for coping with high-frequency or intraday data by using opening, closing, high and low prices for the calculation of volatility, which can create a better picture of fluctuations in high-frequency data.

This study adds to the existing literature on financial spillovers in a number of ways. First, it provides a novel methodology for industry indices construction, which is more accurate for the analysis of industry heterogeneity of spillover effects, compared to global market indices. Second, to our knowledge, it is the first research that has conducted intraday analysis of volatility spillovers between markets based on minute-per-minute data. Third, this paper sheds light on the patterns in information transmission across different industries, and shows that such industries as Healthcare and Industrials are less interconnected between markets than Financials. Fourth, it contributes to the literature on the effect of denominated currency on financial contagion.

\footnotetext{
${ }^{1}$ In this research we do not aim to investigate the effect of the consumer confidence index.
} 
The results can be summarised as follows. First, we find evidence that spillover of asset prices volatility from the US to European markets does exist in the examined period from January 2011 to June 2011. Second, the greatest impact on the volatility in the target markets is observed in the first minute after the increase in asset prices volatility in the US market, and it is highest in the first five minutes over the analyzed period of 30 minutes. It highlights how recent technologies influence markets, making them even more interconnected and exposed to financial contagion. Third, the results show that the level of market interrelation is different among industries. Hence, spillover effects between the US and European markets are less pronounced for Healthcare and Industrials, in contrast to the Financials sector. Therefore, an analysis of financial contagion across industries is desirable and should be conducted with the use of industry indices, instead of global market indices. Finally, we confirm that denominated currency is an important factor affecting the spillover effect of volatility from the US market to the target markets. These results add to further understanding of industry heterogeneity of spillover effects, and can be practically implemented for risk management procedures, short-term trading strategies, as well as being used for the purpose of portfolio diversification and portfolio asset allocation.

The remainder of the paper proceeds as follows. The next section discusses the theoretical framework and empirical evidence for financial contagion. Section 3 describes the data sample, volatility and indices calculations, and model specification. Section 4 presents the empirical results for the volatility spillover effect in European equity markets. Section 5 concludes the study. 


\section{Background of financial contagion}

\subsection{Understanding financial contagion: Empirical evidence}

The definition of financial contagion is a highly debatable issue (Pericoli and Sbracia, 2003). Contagion is most commonly defined as a significant increase in inter-market links conditional on a crisis occurring in one market (Coresetti et al., 2010; Yiu et al., 2010; Forbes and Rigobon, 2001; Chiang et al., 2007; Pritsker, 2000; among others). Caporale et al. (2005) state that financial contagion is a significant increase in the degree of co-movements between stock returns in different countries. Bekaert, Harvey, and Ng (2005) explain contagion as excess correlation, which is the correlation over and above what is expected. Edwards (2000) defines contagion as a situation where the extent and magnitude of the international transmission of shocks exceed what was expected by market participants.

The empirical evidence for the existence of financial contagion is not conclusive. Several studies, such as those of Boyer et al. (1999), Forbes and Rigobon (2002), and Bordo and Murshid (2001), have examined an increase in correlation between asset returns in pairs of crisis-hit countries, and reached the conclusion that there was "no contagion, only interdependence." Corsetti et al. (2005) used the same methodology as Boyer et al. (1999) and Forbes and Rigobon (2002), and found "some contagion, some interdependence." Regarding the contradictory findings, it was stated that the previous result of "no contagion, only interdependence" was obtained due to arbitrary and unrealistic restrictions on the variance of country-specific shocks. Rodriguez (2007) also questioned the results of Forbes and Rigobon (2002). Their evidence states that contagion is not necessarily a nonlinear

phenomenon; therefore, further investigation is required. Several studies among Asian markets have documented the existence of contagion. Chiang, Jeon, and Li (2007) confirmed a contagion effect by applying a dynamic conditional-correlation model to nine Asian daily stock-return data series from 1990 to 2003. Caporale, Cipollini, and Spagnolo (2005) documented the existence of contagion within the East Asian region.

\subsection{Evidence for market integration and transmission channels}

There have been various explanations of how financial contagion can spread between countries, suggesting explaining different transmission channels, trade links between countries, macroeconomic similarities and inter-country financial links. Jeon (2005) provides evidence of financial linkages between countries, emphasising that it was a channel of contagion for currency crisis in the case of the 1997 Asian crisis. Dornbusch et al. (2000) 
investigated the links through which shocks are normally transmitted, and point to the importance of trade and financial links. Longstaff (2010) considers liquidity and the risk premium channel, but in fact gives highest importance to the correlated information channel. This explanation states that tight financial and trade linkages between countries increase volatility transmission, and consequently the information about economic factors may affect multiple markets. Significant number of academic papers have stated an increase in the degree of international financial integration (Agenor, 2003; Lane and Milesi-Ferretti, 2003; Morrison and White, 2004; Vo and Daly, 2007). Pritsker (2001) argues that financial market contagion occurs due to the real linkages between countries driven by common macroeconomic influences, which determine assets values between countries and highlight the importance of the correlated information channel. Recent advanced technologies have increased the speed of information transmission and processing, and made the linkages between international markets (and, as a result, information spillovers) even stronger. Acharya and Yorulmazer (2008) called this effect "information contagion." Hence, nowadays spillover effects may occur not only during a financial crisis, but also on a daily basis.

\subsection{Impact of announcements on inter-country volatility jumps}

The impact of announcements on inter-country jumps in volatility has been examined by many academic studies. Evans (2011) investigated the extent to which statistically significant intraday jumps are associated with US macroeconomic news announcements. The research examined a significant range of macroeconomic news announcements using continuously compounded five-minute returns, and confirmed that one third of jumps correspond to US macroeconomic news announcements. Andersen et al. (2007) exploited a high-frequency futures dataset of five-minute continuously compounded returns, and analyzed the response of US, German, and British stock, bond, and foreign exchange markets to real-time US macroeconomic news. The results confirmed that news produces conditional mean jumps between the markets, with the strongest jumps identified for bond markets. Other papers have investigated the impact of news announcements on inter-country spillover effects; for instance, Chen and Gau (2010) investigated the effect on price discovery in the foreign exchange market; Hussain (2011) focused on the return and volatility response of major European and US equity indices to monetary policy surprises; Arezki, Candelon and Amadou (2011) examined the spillover effects of sovereign rating news on European financial markets during the period of 2007 to 2010. Lahaye, Laurent, and Neely (2011) extracted jumps and co-jumps from three types of assets: stock index futures, bond futures, 
and exchange rates; and found that the fed funds target, NFP, and GDP announcements are important in all markets.

\subsection{Evidence for financial contagion using high-frequency data}

A significant number of academic papers have studied financial contagion using lowfrequency data. Thus, Yiu et al. (2010), Diebold and Yilmaz (2009), Suwanpong (2011), Coresetti et al. (2010), and Caporale et al. (2005) used data on weekly basis. Forbes and Rigodon (2002) and Coresetti et al. (2005) used a shorter time interval of two-day returns in calculating correlations. Another strand of academic papers has studied contagion using daily basis returns (Bessler and Nohel, 2000; Hon et al., 2004; Chiang et al., 2007; Rodrigues, 2007, Aloui et al., 2011; among others).

Only a few papers have used high-frequency data to investigate volatility transmission across markets. $\mathrm{Wu}, \mathrm{Li}$, and Zhang (2005) examined short-run information transmission between the US and UK markets, using five-minute returns of the S\&P 500 and FTSE 100 index futures. To estimate the mean and volatility spillovers of intraday returns, they employed the GARCH model; and a Fourier flexible function was applied to filter the intraday periodic patterns that induce serial correlation in return volatility. The results indicate that the volatility of the US market is affected by the most recent volatility surprise in the UK market. Jung and Maderitsch (2014) examined volatility transmission between stock markets in Hong Kong, Europe and the US for the 2000-2011 time period. The analysis is built based on stock index data sampled at the five-minute frequency. Hussain (2011) analyzed lagged trading activity using five-minute concurrent data from the German and British equity markets, and highlighted the impact of trading volume on stock volatility; however, the research was unable to measure the information transmission mechanism between stock markets. Égert and Kočenda (2007) analyzed co-movements among three stock markets in Central and Eastern Europe, and interdependence between Western European (DAX, CAC, UKX) and Central and Eastern European (BUX, PX 50, WIG 20) stock markets, using five-minute tick intraday price data for stock indices, from mid-2003 to early 2005. They found no robust cointegration relationship for any of the stock index pairs, and documented signs of short-term spillover effects both in terms of stock returns and stock price volatility. 


\subsection{Evidence for industry-level spillover effects}

There is surprisingly limited empirical research on the industry-level spillover effect of volatility, and to our knowledge it has been conducted only for the US markets. Campbell et al. (2001) studied the behaviour of stock market volatility at the market, industry and idiosyncratic firm levels. Their work documents a noticeable increase in idiosyncratic firmlevel volatility relative to market volatility over the period from 1962 to 1997 , and a decline in correlations among individual stock returns and in the explanatory power of the market model for a typical stock. Chiu (2014) provided evidence of volatility transmission and tail risk spillover from the financial sector to many real sectors in the US economy over the period 2001-2011; however, the analysis conducted mainly aimed to identify industry characteristics that drive such spillovers. Wang (2010) investigated the dynamic behaviour of 30 industry-specific risks, and provided evidence that industry-specific volatilities have different behaviours. The findings are in line with our work and show that, even though the market volatility has a substantial influence on various industries, volatility shocks from the financial sector do not transmit to other industries simultaneously. In support, it provided evidence that during recession the market risk premium shrank, while the risk premium associated with the industry factor was less sensitive to the change.

\subsection{New approach of the current research in contrast to the previous literature}

Our research aims to fill the existing gap in the literature on the inter-market industry heterogeneity of spillover effects, and provides inter-country investigation of industry-level volatility spillovers. In this paper we propose a unique methodology of constructing and utilising self-made industry indices, which will help to conduct a more accurate investigation of inter-market industry-spillover effects. We claim that the global indices cannot be applied for the inter-country industry-level analyzes of volatility spillovers, as the weight of each sector in the indices in different countries is not equally represented. The analyzes of financial contagion based on major indices are biased towards some industries, since for each particular country the weight of each sector depends on its relative importance. The novel approach of the self-built industry indices proposed in this research allows the implementation of the same index methodology across different markets, and eliminates the deceptive inferences possible with the use of global market indices. As it is widely known, major world indices are positively correlated with each other; this new approach will provide more information on whether there is a particular industry that moves closer than others with the US market. Thus, it will provide new evidence to the existing literature regarding 
financial contagion and industry-level spillover effects, and may highlight new areas for further research.

In contrast to the existing literature on cross-market volatility transmission and spillover effects, we claim that, due to the fact that new advanced technologies have accelerated the speed of information transmission among markets, inter-market spillover effects should be investigated in very short time periods. Hence, we argue that the impact of the information spillover from the triggered event on target markets should be seen in less than five minutes. The analysis of inter-market volatility transmission with higher time frequencies may not capture the highest impact of information spillovers, simply because by that time it could be already fully absorbed in the markets. As a result, a key innovation of this study is that we use high-frequency minute-per-minute data, and investigate inter-market information spillovers in the first five minutes after the triggered event. Both a unique methodology featuring self-constructed industry indices, and high-frequency minute-perminute data utilized for the analysis, add to the further understanding of industry heterogeneity of spillover effects and will lead to major results. Providing new evidence to the existing literature, this methodology highlights different levels of interconnectedness between sectors analyzed, which, in turn, have an important impact on inter-market volatility transmission. It should be further analyzed in academic research, and provides an idea about the speed of information spillovers from the US to European markets. 


\section{Data and methodology}

\subsection{Data sources and collection procedures}

In this study, the US stock market is used as the originating market, and the following ten Western European stock markets are the target markets: the United Kingdom, France, Ireland, Greece, Sweden, Germany, Belgium, Switzerland, Spain, and Italy. We claim that the contagion analysis through the global stock market indices (e.g., S\&P 500, FTSE 100 or DAX 40) would be too general, given that different industries may have diverse levels of contagion from the originating market. Consequently, we collect minute-per-minute intraday data (opening, closing, high, and low stock prices) from all 374 stocks listed in three industries (Financials, Healthcare, and Industrials), and construct indices for each of them using an equal-weighted approach. ${ }^{2}$ All data were collected from the Bloomberg Terminal by Bloomberg LP. The most common stock indices were used for industry stock selection and collection: the Athens Composite Index (ACI), BEL 20 Index (BEL 20), CAC 40 Index (CAC 40), DAX 30 Index (DAX 30), FTSE 100 Index (FTSE 100), FTSE MIB Index (FTSE MIB), IBEX 35 Index (IBEX 35), ISEQ 20 Index (ISEQ 20), OMX Stockholm 30 (OMXS 30), SMI Index (SMI), and S\&P 500 Index (S\&P 500) for the New York market. The details of the indices and the industry classification standards are listed below.

[Please insert Table 1 here]

As listed in the above table, the classification standards adopted by the 11 indices are not the same. To universalise the classification standards in this paper, ICB was chosen, since more than half of the indices follow this standard. The three common industries' indices were reclassified, with a total of 374 stocks selected, as in the table below:

[Please insert Table 2 here]

As per Table 2 above, for all markets except Madrid, Paris, and Stockholm, the Financials sector has the largest number of stocks in the sample, and in three of the markets its percentage value is above 55 percent. This is a clear sign that analyzes of financial contagion based on major indices are biased towards some industries, as for each particular country the weight of each sector in the indices depends on its relative importance. Therefore,

\footnotetext{
${ }^{2}$ We also performed a price-weighted approach, and the results do not differ significantly.
} 
some markets are more oriented to some sectors than others. For instance, the Industrials sector is relatively more important in Madrid, Paris, and Stockholm, and the Healthcare sector is relatively more important in Frankfurt, New York, and Zurich. Additionally, we had to consider the opening and closing trading times in different markets. To conduct this analysis, some announcements and macroeconomic indicators could not be considered for the analysis of information spillover, since the US and European markets were not both open at the time when the announcement is made; in these cases, information transmission occurred within non-overlapping trading hours. For example, the unemployment rate in the US is announced when European markets are open, while the US market is still closed. In this case, the European markets' reaction will be prior to the US market, which goes beyond the objective of analysing how the increase in volatility in the US market spills over to the European markets. As another example, the Federal Fund rate is announced when European markets are closed, but when the US market is open. Hence, the US market reacts to the announcement prior to the European markets, and consequently the effect of increased volatility in European markets will be seen only on the following day, when the market is open and the effect cannot be judged, since it could be already influenced by other factors than the Federal Fund rate announcement. The consumer confidence index (CCI) was selected among a pool of economic indicators as the triggered event which is released within overlapping trading hours. The official release time 10:00 a.m. EST will be used in the analysis as a commencemen time for the information spillovers. ${ }^{3}$ As discussed previously, the focus of this paper is not to analyze the effect of CCI on the US and European stock markets, but instead, to use this event to test whether the volatility increase in the US stock market generated by the announcement spills over to various European markets. This index reflects households' confidence in their country's economy. Therefore, this confidence indicator broadly affects all sectors of the economy, and provides vital information to the financial markets, as consumer spending accounts for two-thirds of the US domestic product. As a result, we expect that CCI information release will affect all industries analyzed; therefore, $\mathrm{CCI}$ is a good reference point that suits the purpose of this research. During the six months of the sample period analyzed (January-June 2011), the index was announced on January 25, February 22, March 29, April 26, May 31, and June 28.

\footnotetext{
${ }^{3}$ State Street Investor Confidence Index can also be used as a reference point, since it was released at the same date/time during the period analyzed.
} 
Table 3 and Figure 1 show opening, closing times, and the release time for each market analyzed. The information is presented in local time and GMT. The timeline shows a graphical representation of opening market hours in London time.

[Please insert Figure 1 here]

[Please insert Table 3 here]

As is shown in the timeline and in Table 3, the majority of European markets open and close at the same time as London, except for Athens and Milan. For all markets (except Athens), it is possible to analyze intraday data from ten minutes prior to the announcement to thirty minutes after the announcement.

\subsection{Volatility estimation and sector indices calculations}

\subsubsection{Volatility estimation}

In this paper, we consider the occurrence of contagion to be when volatility of asset prices spills over from the "crisis" country to other countries. We use Garman and Klass's (1980) volatility estimator to calculate asset volatility, which differs from the classical volatility estimator that cannot reflect fluctuations within a period. The Garman-Klass estimator is well known for coping with high-frequency or intraday data, using the opening, closing, high, and low prices within a time period for the calculation of volatility, which can create a better picture of fluctuations in high-frequency data. Also, the Garman-Klass estimator was proved to have a much higher efficiency than the classical estimator (Meilijson, 2008; Ślepaczuk and Zakrzewski, 2009). ${ }^{4}$ Garman and Klass (1980) suggested two approaches to calculating the volatility of an asset from its prices within a certain period. Following previous work (Meilijson, 2008; Batten and Lucey, 2007; Yilmaz, 2010; Suwanpong, 2011; Diebold and Yilmaz, 2009), we use the "best analytic scale-invariant" approach to preserve the completeness of the estimator.

\footnotetext{
${ }^{4}$ The high-low-open-close estimator developed by Garman and Klass (1980) is considered to be six or seven times more accurate than the Close-Close (CC) estimator and more efficient than its predecessor, the Parkinson's estimator.
} 
The Garman and Klass (1980) estimator (GKe) is calculated as follows:

$$
G K e=\sigma^{2}=0.511 \log \left(\frac{h}{l}\right)^{2}-0.019\left[\log \left(\frac{c}{o}\right) \log \left(\frac{h l}{o^{2}}\right)-2 \log \left(\frac{h}{o}\right) \log \left(\frac{l}{o}\right)\right]-0.383\left(\log \left(\frac{c}{o}\right)\right)^{2}
$$

where $\mathrm{h}, 1, \mathrm{o}$, and $\mathrm{c}$ represent the initial high, low, open and close prices of the given time period respectively. The volatilities of each minute within the examined time period for each stock are calculated using the above Garman and Klass "best analytic scale-invariant" estimator.

\subsubsection{Sector Indices calculations}

As discussed previously, we use the Garman and Klass analytic scale-invariant estimator $(\mathrm{GKe})$ to calculate stock return variance. Let $\mathrm{O}_{\mathrm{i}}(\mathrm{t}), \mathrm{H}_{\mathrm{i}}(\mathrm{t}), \mathrm{L}_{\mathrm{i}}(\mathrm{t})$ and $\mathrm{C}_{\mathrm{i}}(\mathrm{t})$ be the open, high, low and close prices of the $\mathrm{i}^{\text {th }}$ stock during the $\mathrm{t}^{\text {th }}$ minute respectively. Let $\mathrm{GKe}_{\mathrm{i}}(\mathrm{t})$ be the variance of the $\mathrm{i}^{\text {th }}$ stock during the $\mathrm{t}^{\text {th }}$ minute, which is estimated according to the Garman and Klass variance estimator,

$$
\begin{aligned}
G K e_{i}(t)=0.511 \log \left(\frac{H_{i}(t)}{L_{i}(t)}\right)^{2}-0.019\left[\log \left(\frac{C_{i}(t)}{O_{i}(t)}\right) \log \left(\frac{H_{i}(t) L_{i}(t)}{\left(O_{i}(t)\right)^{2}}\right)-2 \log \left(\frac{H_{i}(t)}{O_{i}(t)}\right) \log \left(\frac{L_{i}(t)}{O_{i}(t)}\right)\right] \\
-0.383\left[\log \left(\frac{C_{i}(t)}{O_{i}(t)}\right)\right]^{2}
\end{aligned}
$$

The above estimated variances are used to compute the required annualized volatilities $A V_{i}(t)$ as,

$$
A V_{i}(t)=\sqrt{G K e_{i}(t) m l}
$$

where $m$ is the number of trading days (assumed to be 252) and 1 represents the number of trading minutes in the market (e.g., 510 trading minutes in US markets). The volatilities of every minute in each stock in the same market and industry are combined to form the annualised volatility of that minute for that market and industry. We adopt the modern portfolio theory by Markowitz (1952) in calculating the portfolio (index) return variance, which can be calculated from the volatility of individual assets in the portfolio. 
Let $\sigma_{\mathrm{p}}^{2}$ represent the portfolio variance, then,

$$
\sigma_{p}^{2}=\sum_{i} \omega_{i}^{2} \sigma_{i}^{2}+\sum_{i} \sum_{j \neq i} \omega_{i} \omega_{j} \sigma_{i} \sigma_{j} \rho_{i j}
$$

where $\omega_{i}$ is the weight of $\mathrm{i}^{\text {th }}$ asset, $\sigma_{i}$ is the volatility of $\mathrm{i}^{\text {th }}$ asset and $\rho_{i j}$ is the correlation coefficient between $\mathrm{i}^{\text {th }}$ and $\mathrm{j}^{\text {th }}$ asset. Thus, the portfolio return volatility would be equal to the square root of the portfolio return variance. Since the portfolio volatility is a function of the correlations of all portfolio component asset pairs, the correlation coefficients were calculated by using 30 minutes' data before the announcement time. The correlation coefficients were assumed and set to be unchanged throughout each sub-period, which may be a limitation, as the correlation between assets should be dynamic and it changes from time to time. Since the volatility of a portfolio is also a function of the weight of each asset in the portfolio, we consider equal weights for all stocks within the portfolio.

\subsection{Volatility spillover effect in European equity markets}

Our analysis is focused on the investigation of lead-lag behaviour and financial spillovers among three different sectors within ten European stock markets. As the markets react to the incoming news, the indices will fluctuate most for a period around the announcement time, showing the investors' reaction to the new incoming information (Ederington and Lee, 1993; Bollerslev et al., 2000). Hence, as the first approach, we will investigate whether volatility transmission from the US to European markets have irregular patterns in the first 30 minutes after the announcement. We extract thirty minutes of data after the release time, and will examine minute-per-minute volatility, starting one minute after the consumer confidence index announcement for each European market and each industry sector, so that we aim to obtain evidence regarding inter-market volatility spillovers and answers on the industry heterogeneity of spillover effects. Moreover, we will analyze the magnitude of the volatility transmission from the US, and whether it may impact particular European markets differently. Hence, the first set of hypotheses to be tested:

Hypothesis 1: There is no volatility transmission and spillover effects from the US market to the European markets.

Hypothesis 2: There are no irregular patterns or jumps in the volatility transmission from the US to European markets during the first 30 minutes after the announcement. 
Hypothesis 3: Different magnitudes of US stock market volatility do not alter the impact of information transition in European markets.

Hypothesis 4: There is no industry heterogeneity of the spillover effects. The speed and magnitude of volatility transmission is equal among the industries analyzed.

In addition, we perform robustness checks by replicating our analysis for the last 30 minutes of the trading day in the European markets, ${ }^{5}$ and for the next trading day, where we apply the same time period as in our original analysis.

Based on our assumption that recent advanced technologies accelerate the speed of information transmission, we expect that the first five minutes will show the greatest volatility, compared to the remaining 25 minutes. Therefore, we test whether volatility spillovers from the US markets can reach European markets in the first five minutes or less. First, we intend to run preliminary tests to establish whether the volatility spillovers that occur in the first five minutes after the announcement are different from those in the remaining 25 minutes. As the next step, we will investigate the minute-per-minute volatility, starting from one to five minutes after the announcement, and will repeat it for the next 30 minutes after the announcement for each European market and industry, in order to control for jumps in volatility transmission within the first five minutes, and its patterns. The minuteper-minute impact of US market volatility on European markets will be also analyzed, by controlling the impact of one-minute US market volatility on the next minute in other markets. In order to complete our analysis, we included additional tests to assess the impact of market denominated currency on inter-market volatility spillovers.

Therefore, another set of hypotheses are to be tested:

Hypothesis 5: There are no spikes in volatility transmission during the first five minutes after the announcement.

Hypothesis 6: The impact of volatility spillovers from the US is equal for all European countries.

Hypothesis 7: Market denominated currency has no impact on the magnitude of inter-market volatility spillover effects.

\footnotetext{
${ }^{5}$ For most markets, intraday volatility is greatest just after the opening (as results are often announced around the opening) and just before the close (performance is often based upon closing prices).
} 
The regression equation can be defined as follows:

$$
G K e_{m, i, t+1}=\alpha+\beta_{1} G K e_{-} U S_{i, t}+\sum_{k=1}^{L} \beta_{2, k}\left(G K e_{-} U S_{i, t} \times D_{m, k, t}\right)+\varepsilon_{m, i, t}
$$

Where $G K e$ is the stacked vector of the dependent variable, representing the volatility ${ }^{6}$ starting one minute after the consumer confidence index announcement for each $\mathrm{m}^{\text {th }}$ European market and $\mathrm{i}^{\text {th }}$ industry index on the $\mathrm{t}^{\text {th }}$ minute, GKe_US is a vector with the volatility for each $\mathrm{i}^{\text {th }}$ US industry index, starting at the minute of the consumer confidence index announcement, and D is a matrix of dummy variables that controls for large increases of volatility observed in the US market indexes in the first five minutes, industry sectors, markets, and denominated market currency.

In addition, in further robustness checks we will conduct the analysis of cross-market volatilities 25 minutes before the release time and 25 minutes after the first five minutes, and compare these results with those of the first five minutes. The results should confirm the expectations regarding the surge in volatility in the first five minutes after the announcement, and will show whether 'normal' volatility patterns could be observed prior to the announcement and after the first five minutes after the release time.

Our expectations for further hypothesis testing are based on the Figures 2 to 4 (inserted below), which show the average minute-per-minute annualised volatility aggregated for the six consumer confidence index announcements, calculated for ten minutes before and thirty minutes after the announcement time, with the volatility presented for the US and European markets analyzed. ${ }^{7}$ The figures clearly display a surge followed by a plunge in volatility in the US, followed by European markets, with most of this effect occurring in the first five minutes. It raises further interest in investigating the inter-market volatility spillovers within the identified five-minute interval. Additional minute-per-minute empirical tests are required to provide more detailed information on the speed of inter-market volatility transmission. Also, based on the results displayed in Figures 2 to 4, it is evident that US market is less volatile than the aggregation of the ten European markets, in particular for the Financials and Healthcare sectors. ${ }^{8}$ It indicates the necessity of investigating further the

\footnotetext{
${ }^{6}$ Note that 'volatility', as calculated by the Garman-Klass estimator, represents the variance but not the standard deviation of an asset price.

${ }^{7}$ Figures reporting each announcement and each European market individually are available upon request.

${ }^{8}$ Further analysis will show that it is not the case when the European markets are analyzed individually.
} 
industry heterogeneity of spillover effects, and patterns of volatility spillovers across different industries.

[Please insert Figure 2 to 4 here] 


\section{Empirical results}

\subsection{Volatility spillover effect in European equity markets}

\subsubsection{Preliminary results}

Before conducting formal hypothesis testing, we first analyze the effect of the US consumer confidence index announcements on the US stock market volatility and its contagion to the European stock markets. We test whether the announcement generates a substantial increase in stock market volatility in the US and European markets in the first five minutes after the release time, and estimate the increase by calculating simple averages of the volatility for the first five minutes after each announcement. We include binary variables in order to control for a substantial increase in volatility, quantified as above 30, 40, 50 and 60 percent. The results are controlled by industry (Healthcare and Industrials, with Financials being the basis case), in order to examine whether some industries are more interconnected than others.

Table 4 presents the preliminary statistics, with the percentage of observations in the five-minute interval per sector; so that it shows increased volatility in the US and European stock markets after the consumer confidence index announcement.

[Please insert Table 4 here]

According to the results, for all observations in the Financials sector for the US market, there is at least a 30 percent increase in volatility after the announcement. This could indicate that the increase in volatility is somehow independent of whether the content of the news announced is in line with the analysts' forecasts. For the other two sectors, the results show a different pattern. For the Industrials we observe extreme values. For one half of the observations the increase in volatility is less than 30 percent, and for the other the increase is above 60 percent. Healthcare's jump in volatility after the announcement is spread among all the five thresholds (less than 30 and above 30, 40, 50, and 60 percent volatility increase), in over 50 percent (two thirds) of the observations. These preliminary results show clear evidence of different levels of reaction per sector after the announcement, which confirms the need for analysing sectors independently. This accord with the findings of Wang (2010), who documented that volatility shocks from the finance sector do not transmit to other industries simultaneously. For European markets, the results show a different pattern. First, for all sectors, the volatility increase is highly concentrated in the extreme values, with the number 
of observations in the extreme values of volatility increasing between 87 and 95 percent, on average. Second, the Financials sector demonstrates the largest percentage of observations, with an increase in volatility of above 60 percent. Third, for Healthcare, more than 40 percent of the observations are below a volatility increase of 30 percent.

As the next step, we test whether the volatility increase during the first five minutes is different from that in the remaining 25 minutes following the announcement, and conduct a similar analysis to the previous instance, but in this case we calculate simple averages of the volatility for each minute. Table 5 reports the average volatility for the US and the ten European stock markets, analyzed per industry.

\section{[Please insert Table 5 here]}

The results show that the average volatility levels for the European markets are higher compared to the US, independently of the industry. There is a clear tendency of volatility decreasing over the first five minutes starting from the first minute, which is persistent across all the three industries in both the US and European markets, on average. Industrials is the least volatile sector in the European markets, but has the highest volatility in the US. The opposite situation is observed for Healthcare. For European markets, Financials shows the highest combined volatility in the first two minutes, with Healthcare showing that pattern in the remaining three minutes. The results for the European markets among the industries are aligned with the results from the announcement effect on volatility for the different industries in the US. Indeed, this confirms that an analysis of financial contagion across industries is preferable to the use of global market indices. Additionally, when we compare the average volatility for the remaining 25 minutes with that of the initial five minutes, there is clear evidence of a substantial decrease, statistically significant at the one percent level when a Wilcoxon rank-sum (Mann-Whitney) test is performed. This reduction in volatility is observed in both the US and European markets, and across all industries, with 48.6 (40.5), 45.8 (80.7), and 45.7 (56.6) percent for Financials, Healthcare, and Industrials respectively in the US (European markets).

In Table 6 (Panel A) we extend the analysis of the observed increase in volatility after the announcement, and compare the first five minutes with the next 25 minutes for the US and each European market individually. We apply the Wilcoxon rank-sum (Mann-Whitney) 
test in order to examine whether the volatility transmission for each industry and market for two different time periods are different; for instance, it might be higher for some markets and industries in a particular time period. A significant $\mathrm{Z}$ value indicates that two samples analyzed are not the same. The results clearly support that, in nearly 80 percent of the cases, there are significant differences between the average volatility in the first five minutes after the announcement and in the next 25 minutes. Particularly for the Financials sector, all European plus the US markets show a statistically significant decrease in volatility from the first five to the next 25 minutes. The Industrials sector shows less evidence of transmission, even though it can be observed for the US and five European markets. In Panel B we test the statistical difference between the US market volatility vis-à-vis European market volatilities for the first five and next 25 minutes after the announcement, and per sector. We can confirm different volatility levels among US market and European markets for the first five and next 25 minutes after the announcement, on average, which supports the importance of analysing industries independently in the study of volatility spillovers.

[Please insert Table 6, Panels A and B here]

\subsubsection{Testing for volatility spillover effects and the evidence for contagion}

At this stage we begin empirical testing of the initially stated Hypotheses 1-4, with the intention to investigate whether we can confirm that there is evidence of the spillover effects from the US markets to the European markets, and whether the volatility transmission from the US to the European markets shows any irregular patterns in the first 30 minutes after the announcement. We apply the baseline model (Equation 1) and perform six different regressions, with various specifications in the dependent variables. Healthcare and Industrials were included as binary variables to control for industry-level volatility effects; $30,40,50$ and 60 percent binary variables are used to provide more insights on whether different magnitudes of the US stock market volatility may alter or enhance the impact triggered by the information transmission in European markets. Table 7 summarizes the results.

[Insert Table 7 here] 
The findings reveal that we can reject all four aforementioned hypotheses. It is shown that, on average, a one percent increase in the US market volatility has a substantial effect, between 0.536 and 1.028 percent, on the next minute's volatility in the European markets (statistically significant at the one percent level). The results are the same, whether or not we control for sector. It can be expected that a substantially increased volatility in the US market during the first five minutes will lead to a marginal increment in the spillover effect between the US and European markets. In fact, the results show that when the increase is above 40, 50 or 60 percent there is a positive incremental effect in the European markets' volatility of 17.6, 21.0, and 29.7 percent respectively. ${ }^{9}$ More interestingly, the spillover effect between the US and European markets is less pronounced for Healthcare and Industrials, in contrast to the Financials sector. This result is related to the fact that in seven out of ten European markets analyzed, the Financials industry represents the largest sector (by number of stocks) in the major index. Therefore, these results show evidence that contagion from the US to European markets does exist, and that the amplitude is different from industry to industry. Different levels should be partially driven by the relative importance of each industry in the global domestic market index.

Furthermore, we extend the previous analysis by identifying at which minute the impact from the US market is the highest, within the five minutes analyzed. We investigate whether there is evidence that confirms almost instantaneous volatility transmission between markets, and identify the time of major spikes; if not, the results will align with our previously stated Hypothesis 5, that there are no spikes during the first five minutes after the announcement. For this purpose we run additional regressions, with the lag of one to five minutes for the next 30 minutes after the US announcement. Table 8 reports a summary of the results.

[Insert Table 8 here]

The regressions are estimated individually for each time lag and volatility jump $(30,40,50$, and 60 percent). Panel A reports the overall results for the 40 percent volatility jump. Panel B describes the summary of findings for the different volatility jump coefficients in relation to each time lag.

\footnotetext{
${ }^{9}$ Results are obtained by the interaction term between the US volatility and binary variables that account for volatility increases above $30,40,50$, and 60 percent.
} 
The findings displayed in Panel A for the coefficients GKe_US, Healthcare, and Industrials are reported for 40 percent increase in volatility after the announcement. ${ }^{10}$ Panel B summarizes different volatility jump coefficients in respect to each time lag. Overall, the tests show a strong lead-lag relationship between the US and European Stock markets. Based on the results, we reject the null hypothesis 5, and provide evidence that the greatest impact on volatility in the target markets is observed in the next minute after the increase in asset prices volatility in the US market. This is followed by an average drop in the marginal effect in the European markets from 0.983 to 0.615 as the time lag moves from one to five minutes, which is statistically significant at the one percent level. This means that a one percent increased volatility in the US market after the announcement has, on average, a positive impact of 0.983 percent in the next minute in the ten European markets, and shows a decreasing effect in the following four minutes. The positive value of the constant reflects the average higher volatility levels for the sample of European markets compared to the US. Furthermore, the volatility jumps in the US market have a statistically significant impact on the volatility increase in the European markets, independently of the time lag analyzed. Finally, once again the results show that the Healthcare and Industrials sectors are less interconnected among markets, compared to the Financials sector.

Even though there is clear evidence of a magnified one-minute spillover in a 30minute interval after the announcement, we re-test the spillover effect for only the first fiveminute period after the announcement for the European markets as a whole, and per country individually. The results are presented in Table 9.

\section{[Insert Table 9 here]}

We regress the volatility in the US market, including additional interaction between the US volatility and binary variables, which accounts for a volatility increase in the US market through the first minute to the fourth minute (with a value of one if there is an increase in the observed volatility compared to the previous minute). Our dependent variable, as before, is the one-minute volatility starting at the minute after the consumer confidence index announcement for each $\mathrm{m}^{\text {th }}$ European market and $\mathrm{i}^{\text {th }}$ sector index for the next five minutes. The explanatory variables are now four interacted variables between the volatility

\footnotetext{
${ }^{10}$ Tables for each volatility jump (30, 50 and 60 percent) are available in Appendix A.
} 
for each $\mathrm{i}^{\text {th }}$ US sector index, and a binary variable equal to one if there is an increase in volatility in each of the first four minutes following the announcement, and zero otherwise. ${ }^{11}$ The model also controls (one at the time) whether the volatility increase in the US market is above 30, 40, 50 or 60 percent. The results (Panel A) for a volatility increase of 40 percent $^{12}$ show that, for the European markets analyzed as a whole, the first and the third minutes' increase in volatility in the US market have a positive marginal effect on European markets' volatility (statistically significant at the one and five percent levels). This shows that, when there is an increased volatility in the US market in the first minute after the announcement, it leads to, on average, a statistically significant positive incremental effect of 0.837 in the ten European stock markets. This coefficient for the first minute after the announcement is the largest, confirming the importance of the use of minute-per-minute data. This evidence confirms our statement that, due the advances in technologies, information spreads between markets very rapidly, almost simultaneously. It also accords with the evidence regarding higher inter-market integration (Kaltenhäuser, 2002; Kearney and Lucey, 2004; Lane and Milesi-Ferretti, 2003). These results are robust among different markets, with positive coefficients across all European markets for the first minute. In addition, we can highlight the minor importance of a second minute increase in the US market volatility, where negative coefficients were observed for eight out of ten markets. In fact, the European markets seem to not react to that information, but a third minute, in case of increased volatility, has an important impact on the European markets. Maybe it can somehow be linked to the content of the information announced. This idea is similar to that of Picou and He (2007), who state that the effect of spillovers may be delayed, meaning the markets that follow in trading need additional time to efficiently incorporate the value of the information. Based on the results, a volatility rise in the US market in the third minute has a positive marginal effect of 0.67 percent on the average volatility of the European markets in the fourth minute. This evidence shows a significant irregular increase in volatility that provides evidence for the highest spillover effect during the first five minutes after the announcement, with the major spike in the first minute. Moreover, the results show that we can also reject Hypothesis 6, since volatility spillovers from the US do not have an equal impact on all European countries. The outcomes emphasise the larger positive effect of increased volatility from the US market to

\footnotetext{
${ }^{11}$ We excluded the variable $G K e_{-} U S$ (baseline effect, standalone coefficient of volatility) from the regressions performed in table 9 , since this variable is perfectly positively correlated with the variable GKe_US $\times 1^{\text {st }}$ minute. Moreover, an increase in volatility after the CCI announcement (independently of the industry sector) stands for all observations in the US market.

${ }^{12}$ Tables for each volatility jump (30, 50 and 60 percent) are available in Appendix B. Panel B summarizes different volatility jump coefficients in relation to each time lag.
} 
Paris, Frankfurt, London, Madrid, and Stockholm, with coefficients of 0.637, 1.226, 0.759, 1.268 and 0.819 respectively. The effects on the remaining markets tend to be smaller. As a possible explanation, we can state that these markets are of less interest to institutional and international investors.

As the last step, we control our results by European country denominated currency (euro, sterling, Swiss franc, and Swedish krona), with the objective to explore whether market denominated currency impacts the market spillover; therefore, we consider Hypothesis 7 as a null hypothesis. For this analysis we include the industry and the market/country currency denomination in the regression analysis (Table 10). Besides two binary variables to control the marginal effect of each industry, two additional binary variables are included, to investigate how market currency denomination impacts spillover effect. ${ }^{13}$ The results confirm the spillover effect among the US market and European markets at an aggregate level and per country. In seven out of ten individual regressions per European market, the coefficient is positive and statistically significant. ${ }^{14}$

[Insert Table 10 here]

The average difference of an increase in volatility in the US market between markets denominated in euros and other currencies is of 6.2 percent. Based on the results, we can reject the previously mentioned null hypothesis 7 , and state that euro-denominated markets amplify the spillover effect of volatility from the US market. This finding is aligned with that of Gebka and Karoglou (2012), who investigated the integration of the EU markets and documented that financial integration intensified in anticipation of the euro, further strengthened by the EMU inception, and was amplified in response to the 2007/2008 financial crisis. As another reason, we can state that this result may be driven by euroincreased volatility from the sovereign debt crisis (consistent with Grammatikos and Vermeulen, 2011). The analysis was also conducted in opposition to the British pound, Swiss franc, and Swedish krona during the sample period. No particular differences were found among the denominations in Swiss francs and Swedish krona in relation to the British pound.

\footnotetext{
${ }^{13}$ Currencies are divided into euro, British pound, and others (Swiss franc and Swedish krona).

${ }^{14}$ The results reported (Table 10, Panel A) are presented for a volatility increase of 40 percent. Table 10, Panel B summarize the different volatility jump coefficients to each time lag. Panel B summarizes different volatility jump coefficients in relation to each time lag. Tables for each volatility jump (30, 50 and 60 percent) are available in Appendix C.
} 
After including in the analysis the binary variable, which indicates volatility increase in the US market after the first minute, more interesting results were observed. The second minute after the announcement in the European markets is strongly significant for such markets as Athens, Brussels, and Dublin, where no evidence of a one-minute spillover was observed. The converse situation was detected for Paris, Frankfurt, London, Madrid, Milan, and Stockholm. This could indicate that some European markets incorporate new information quicker than others due to their development, whereas it takes more than one minute for the volatility increase from the US market to reach other markets. Thus, we agree with Furstenberg (1998), who confirmed that the level of international financial integration is dependent on the level of domestic financial development.

\subsection{Robustness of the results}

Our results show that volatility is substantially higher in the first five minutes after the consumer confidence index announcement, and steadily declines for the next 25 minutes. To perform the robustness checks, we test whether the average volatility of the 25 minutes before the announcement and the 25 minutes after the first five minutes for each sector (Financials, Healthcare, and Industrials) for the European markets are equal (no rejection of the null hypothesis that they are the same). Our results clearly indicate that we cannot reject the hypothesis that the average volatility per European industry sectors in the 25 minutes before the announcement and the 25 minutes after the first five minutes post-announcement are the same. This is an important result, since it confirms that, on average, the observed spike in volatility from the announcement is absorbed within the first five minutes. Additionally, we test and reject the hypothesis that the average volatility per sector in the 25 minutes before the announcement and the first five minutes post-announcement are the same. Results are reported in Table 11.

\section{[Insert Table 11 here]}

As is widely known, intraday equity volatility is higher at the opening and closing market hours, which can be explained by the impact of information accumulated from other markets. To check whether our results are biased according to the time of the announcement, or could be driven by other information accumulated from different markets, we re-estimated Model 1 from Table 7 for the last 30 trading minutes on the day of the announcement for the European markets. Table 12 shows that a one percent increase in the US market volatility has 
a substantially lower effect in the next minute's volatility in the European markets, when compared with the major results for the 30 minutes after the announcement. Finally, we replicate the previous analysis, but on the day after the announcement for the same time period analyzed (the following 30 minutes, starting at 15:00 GMT). The results similarly show that the effect of volatility transmission from the US to European markets is lower on the next day, compared to the announcement day. The results once again confirm the contagion effect following the announcement.

\section{[Insert Table 12 here]}

As final robustness test, we estimated an autoregressive model to complement the results from Table 9, which examine the lagged effect of US volatility in the European markets. Table 13 reports the results of this model (for a 40 percent volatility increase) ${ }^{15}$ and shows a statistically significant one minute lag volatility effect among the US and European markets, and no statistical significant effect when the lag is increased ${ }^{16}$.

\section{[Insert Table 13 here]}

\footnotetext{
${ }^{15}$ Tables for each volatility jump (30, 50 and 60 percent) are available in Appendix D.

16 The lagged effect ( $t-4)$ is significant for Paris, Frankfurt, London, and Stockholm. For only one industry sector in each market it is statistically significant (Paris- Healthcare, Frankfurt- Financials, London-Financials and Stockholm-healthcare); whereas, the one minute lag is positive and statistically significant for all industry sectors. This could be driven by firm-specific events/announcements, which we cannot control in our analysis due to data limitations.
} 


\section{Conclusions}

This paper investigates the existence of financial contagion between the US and ten European stock markets. Using intraday minute-per-minute data of a large set of 374 equities from three different industries over the period from January to June 2011, we investigate the impact of increased volatility in the US on the inter-country industry level spillover effect. The findings confirm the effect of contagion that spills over from the US to European markets; the greatest impact on the volatility in the target markets is observed in the first minute after the increase in asset prices' volatility in the US market, and it is highest in the first five minutes over the period of 30 minutes analyzed. After the fifth minute, the volatility stabilizes to a level that is, on average, equal to that before the volatility increase in the US. Most interestingly, we discovered that the first and the third minutes' increases in volatility in the US market have a positive marginal effect on European market volatility (statistically significant at the one percent level). We claim that the first minute's increase can be explained by the fact that, nowadays, advanced technologies are capable of transmitting information between markets almost simultaneously, which makes markets even more integrated. The third minute's increase, however, may be linked to the content of the information transmitted, which is similar to the findings of Picou and $\mathrm{He}$ (2007), who state that the effect of spillovers may be delayed, meaning that markets that follow in trading need additional time to efficiently incorporate the value of the information. Other results show a different response to the increased level in volatility among industries analyzed, which is consistent with the results of Wang (2010), who documented that volatility shocks from the finance sector do not transmit to other industries simultaneously. Thus, we document that the Healthcare and Industrials sectors are less interconnected across markets analyzed, compared to the Financials sector. The analysis of the impact of market denominated currency on the inter-market spillover effect revealed that, for a market denominated in the euro, the effect of an increase in volatility in the US market is amplified, with an average marginal increase in volatility of 7.9 percent. Hence, we state that euro-denominated markets amplify the spillover effect of volatility from the US market. This finding is aligned with that of Gebka and Karoglou (2012), who investigated the integration of the EU markets, and documented that financial integration intensified in anticipation of the euro, was further strengthened by the EMU inception, and was amplified in response to the 2007/2008 financial crisis. Moreover, for such markets as Athens, Brussels, and Dublin, the spillover effect was observed in the second minute after the announcement. To explain this fact, we corroborated a statement of Furstenberg (1998), that "the level of international financial integration is dependent on the 
level of domestic financial development." Finally, such markets as Paris, Frankfurt, London, Madrid, and Stockholm receive a larger positive impact from the US market volatility relative to other markets, as they are regarded as the primary focus of the institutional and international investors. Overall, we claim that this research provides a significant contribution to the existing evidence regarding inter-country contagion effect and industry-level spillover effects. To our knowledge, it is the first occasion on which the spillover effect has been examined using minute-per-minute data. The research was conducted by examining the transmission effect from the US to European stock markets, and could be continued in further research by examining inverse or bi-directional industry-level spillover effects. 


\section{References}

Acharya, Viral V., and Tanju Yorulmazer (2008) "Information contagion and bank herding" Journal of Money, Credit and Banking 40.1, 215-231

Agénor, Pierre-Richard (2003) "Benefits and costs of international financial integration: theory and facts" The World Economy26.8, 1089-1118

Aloui, R., Ben Aïssa, M.S., Nguyen, D.K. (2011) "Global financial crisis, extreme interdependences, and contagion effects: the role of economic structure?" Journal of Banking and Finance 35 (1), 130-141

Andersen, Torben G., Tim Bollerslev, and Francis X. Diebold (2007) "Roughing it up: Including jump components in the measurement, modelling, and forecasting of return volatility" The Review of Economics and Statistics 89.4, 701-720

Arezki, Rabah, Bertrand Candelon, and Amadou Sy (2011) "Sovereign rating news and financial markets spillovers: Evidence from the european debt crisis" IMF working papers, 1-27

Baillie, Richard T., and Tim Bollerslev (2000) "The forward premium anomaly is not as bad as you think."Journal of International Money and Finance 19.4, 471-488

Batchelor, Roy, and Pami Dua (1998) "Improving macro-economic forecasts: The role of consumer confidence" International Journal of Forecasting 14.1, 71-81

Batten, J.M. and Lucey, B.M. (2007) "Volatility in the Gold Futures Market”, Discussion Paper \# 225, Institute for International Integration Studies

Bekaert G., C.R. Harvey and A. Ng. (2005) “Market integration and contagion”, Journal of Business, 78(1), 3970

Bessler, Wolfgang, and Tom Nohel (2000) “Asymmetric Information, Dividend Reductions, and Contagion Effects in Bank Stock Returns" Journal of Banking and Finance (November): 1831-49

Bordo, Michael D., and Antu Panini Murshid (2001) "Are Financial Crises Becoming More Contagious? What is the Historical Evidence on Contagion?" International Financial Contagion. Springer US, 1, 367-403.

Boyer, B.H., Gibson, M.S., Loretan, M. (1999) "Pitfalls in tests for changes in correlations" International Finance Discussion Paper, No. 597R, Federal Reserve Board

Campbell, John Y., Martin Lettau, Burton G. Malkiel, and Yexiao Xu (2001), Have individual stocks become more volatile? An empirical exploration of idiosyncratic risk", Journal of Finance 56, 1-44

Caporale G. M., Cipollini A. and Spagnolo N. (2005) "Testing for Contagion: A conditional correlation analysis", Journal of Empirical Finance, Vol. 12, 3, pp.476-489

Corsetti, Giancarlo, Marcello Pericoli, and Massimo Sbracia (2005) "'Some contagion, some interdependence’: More pitfalls in tests of financial contagion" Journal of International Money and Finance 24.8 11771199

Corsetti, Giancarlo, Marcello Pericoli, and Massimo Sbracia (2011) "Correlation analysis of financial contagion" Financial Contagion: The Viral Threat to the Wealth of Nations, 11-20.

Chen, Shiu-Sheng. "Lack of consumer confidence and stock returns (2011) "Journal of Empirical Finance, 18.2 225-236

Chen, Yu-Lun, and Yin-Feng Gau (2010) "News announcements and price discovery in foreign exchange spot and futures markets" Journal of Banking \& Finance34.7, 1628-1636

Chiang, Thomas C., Bang Nam Jeon, and Huimin Li (2007) "Dynamic correlation analysis of financial contagion: Evidence from Asian markets." Journal of International Money and Finance 26.7, 12061228

Chiu WC, Peña JI, Wang CW (2014) “Industry characteristics and financial risk contagion” Journal of Banking and Finance, forthcoming

Diebold, Francis X., and Kamil Yilmaz (2012) "Better to give than to receive: Predictive directional measurement of volatility spillovers" International Journal of Forecasting 28.1, 57-66

Dornbusch, Rudiger, Yung Chul Park, and Stijn Claessens (2000) "Contagion: understanding how it spreads" The World Bank Research Observer 15.2, 177-197 
Ederington, Louis H., and Jae Ha Lee (1993) "How markets process information: News releases and volatility" The Journal of Finance 48.4, 1161-1191

Edwards, Sebastian (2000) "Contagion "The World Economy23.7, 873-900

Égert, B., Kočenda, E. (2007) "Interdependence between Eastern and Western European stock markets: evidence from intraday data" Econ. Syst. 31 (2), 184-203

Evans, Michael D., and Trevor Chamberlain, "Measuring the Effects of Monetary and Fiscal Policy Changes on the US Economy (1982-2012)", working paper

Evans, Kevin P. (2011) "Intraday jumps and US macroeconomic news announcements" Journal of Banking \& Finance 35.10, 2511-2527

Forbes, Kristin J., and Roberto Rigobon (2002) "No contagion, only interdependence: measuring stock market comovements" The Journal of finance 57.5, 2223-2261

Forbes, Kristin, and Roberto Rigobon (2001) "Measuring contagion: conceptual and empirical issues." International Financial Contagion, Springer US, 43-66

Von Furstenberg, George M. (1998) "From worldwide capital mobility to international financial integration: a review essay "Open Economies Review, 9.1 53-84

Garman, Mark B., and Michael J. Klassv (1980) "On the estimation of security price volatilities from historical data" Journal of business, 67-78

Gębka, Bartosz, and Michail Karoglou (2013) "Have the GIPSI settled down? Breaks and multivariate stochastic volatility models for, and not against, the European financial integration" Journal of Banking \& Finance, 37.9, 3639-3653

Gelper, Sarah, Aurélie Lemmens, and Christophe Croux (2007) "Consumer sentiment and consumer spending: decomposing the Granger causal relationship in the time domain" Applied Economics39.1, 1-11

Grammatikos, Theoharry, and Robert Vermeulen (2012) "Transmission of the financial and sovereign debt crises to the EMU: Stock prices, CDS spreads and exchange rates" Journal of International Money and Finance $31.3,517-533$

Grammig, Joachim, Michael Melvin, and Christian Schlag (2005) "Internationally cross-listed stock prices during overlapping trading hours: price discovery and exchange rate effects" Journal of Empirical Finance 12.1, 139-164

Hon, M.T., Strauss, J., Yong, S.K. (2004) “Contagion in financial markets after September 11: Myth or reality?" Journal of Financial Research 27, 95-114

Howrey, E. Philip (2001) "The predictive power of the index of consumer sentiment (2001) "Brookings papers on economic activity, 1, 175-216

Hussain, S.M. (2011) "Intraday trading volume and international spillover effects" Research in International Business and Finance 25, 183-194

Jansen, W. Jos, and Niek J. Nahuis (2003) "The stock market and consumer confidence: European evidence." Economics Letters 79.1, 89-98

Jeon, Bang Nam (2005) "Financial links and contagion in the 1997 Asian currency crisis: an empirical examination" Contemporary Studies in Economic and Financial Analysis 86, 101-114

Jung, R., Maderitsch, R. (2014) "Structural breaks in volatility spillovers between international financial markets: contagion or mere interdependence?” Journal of Banking \& Finance, forthcoming

Kaltenhauser, B. (2002) "Return and volatility spillovers to industry returns: does EMU play a role?" Working paper, CFS (Centre for Financial Studies)

Kearney, Colm, and Brian M. Lucey (2004) "International equity market integration: Theory, evidence and implications" International Review of Financial Analysis 13.5, 571-583

Lane, Philip R., and Gian Maria Milesi-Ferretti (2003) "International financial integration" IMF Staff Papers, $82-113$

Lahaye, Jérôme, Sébastien Laurent, and Christopher J. Neely (2011) "Jumps, co-jumps and macro announcements" Journal of Applied Econometrics 26.6, 893-921 
Longstaff, Francis A. (2010) "The subprime credit crisis and contagion in financial markets" Journal of Financial Economics 97.3, 436-450

Ludvigson, Sydney C. (2004) "Consumer confidence and consumer spending" Journal of Economic perspectives, 29-50

Markowitz, Harry.(1952) “Portfolio selection” Journal of Finance 7.1, 77-91

Meilijson, Isaac. (2008) "The Garman-Klass volatility estimator revisited." arXiv preprint arXiv:0807.3492

Morrison, Alan D., and Lucy White (2004) "Financial liberalisation and capital regulation in open economies "University of Oxford and Harvard Business School working paper

Otoo, Maria Ward (1999) "Consumer sentiment and the stock market" working paper

Pericoli, Marcello, and Massimo Sbracia (2003) "A primer on financial contagion" Journal of Economic Surveys $17.4,571-608$

Picou, A. \& He, L. (2007) “An Examination of Five Markets for Immediate, Delayed and Enduring Spillovers with Control for Periodic Closures” Journal of International Business and Economics, 7 (1), 111-127.

Pritsker, Matt (2001) "The channels for financial contagion" International financial contagion, Springer US, 6795

Rigobon, Roberto (2003) "On the measurement of the international propagation of shocks: is the transmission stable?" Journal of International Economics 61.2, 261-283

Rodriguez, J.C. (2007), "Measuring financial contagion: a copula approach, Journal of Empirical Finance, 14(3), 401-423

Ślepaczuk, Robert, and Grzegorz Zakrzewski (2009) "Emerging versus developed volatility indexes. The comparison of VIW20 and VIX index" Working paper

Suwanpong, P. (2011), "Measuring Return and Volatility Spillovers in Global Financial markets”, Faculty of Economics, Chulalongkorn University, working paper

Van Oest, Rutger, and Philip Hans Franses (2008) "Measuring changes in consumer confidence" Journal of Economic Psychology 29.3, 255-275

Yilmaz, Kamil (2010) "Return and volatility spillovers among the East Asian equity markets" Journal of Asian Economics 21.3, 304-313

Yiu, Matthew S., Wai-Yip Alex Ho, and Daniel F. Choi (2010) "Dynamic correlation analysis of financial contagion in Asian markets in global financial turmoil" Applied Financial Economics 20.4, 345-354

Vo, Xuan Vinh, and Kevin James Daly (2007) "The determinants of international financial integration" Global Finance Journal 18.2, 228-250

Wang, Z. (2010) "Dynamics and causality in industry-specific volatility" Journal of Banking \& Finance 34 (7), 1688-1699

Weder, Mark (1998) "Fickle consumers, durable goods, and business cycles" Journal of Economic Theory 81.1 $37-57$

Wu, C., Li, J. and Zhang, W. (2005) "Interdaily periodicity and volatility spill-overs between international stock index futures markets", Journal of Futures Markets, Vol. 25, pp. 553-85 


\section{Table 1: Indices used and their classification standards}

This table reports the global stock market indices used for the stock selection. The US and ten Western European markets are presented: New York, Athens, Brussels, Paris, Frankfurt, London, Milan, Madrid, Dublin, Stockholm and Zurich. The industry classification standards are reported where GICS stands for Global Industry Classification Standard, ICB for Industrial Classification Benchmark and IGBM for Madrid Stock Exchange General Index

\begin{tabular}{lll}
\hline \multicolumn{1}{c}{ Markets } & \multicolumn{1}{c}{ Indices } & \multicolumn{1}{c}{ Classification Standards } \\
\hline New York & S\&P 500 & GICS \\
Athens & Athens Composite Index & ICB \\
Brussels & BEL 20 & ICB \\
Paris & CAC 40 & ICB \\
Frankfurt & DAX 30 & Prime Standard \\
London & FTSE 100 & ICB \\
Milan & FTSE MIB & ICB \\
Madrid & IBEX 35 & IGBM \\
Dublin & ISEQ 20 & N/A \\
Stockholm & OMXS 30 & GICS \\
Zurich & SMI & ICB \\
\hline
\end{tabular}

Table 2: Number of stocks by market and industry

This table reports per global stock market index the number of stocks collected for the three different sectors: Financials, Healthcare, and Industrials.

\begin{tabular}{lcccc}
\hline \multicolumn{1}{c}{ Index } & Financials & Healthcare & Industrials & Total \\
\hline S\&P 500 & 82 & 51 & 62 & 195 \\
Athens Composite Index & 9 & 1 & 9 & 19 \\
BEL 20 & 6 & 2 & 2 & 10 \\
CAC 40 & 6 & 2 & 8 & 16 \\
DAX 30 & 5 & 4 & 5 & 14 \\
FTSE 100 & 24 & 4 & 13 & 41 \\
FTSE MIB & 12 & 1 & 7 & 20 \\
IBEX 35 & 8 & 1 & 10 & 19 \\
ISEQ 20 & 3 & 2 & 3 & 8 \\
OMXS 30 & 5 & 2 & 11 & 18 \\
SMI & 5 & 5 & 4 & 14 \\
TOTAL & 165 & 75 & 134 & 374 \\
\hline
\end{tabular}

\section{Figure 1: Trading hours and consumer confidence index announcement time under} London time

The figure below reports the market open and close times (GMT) for The US and ten Western European markets: New York, Athens, Brussels, Paris, Frankfurt, London, Milan, Madrid, Dublin, Stockholm and Zurich.

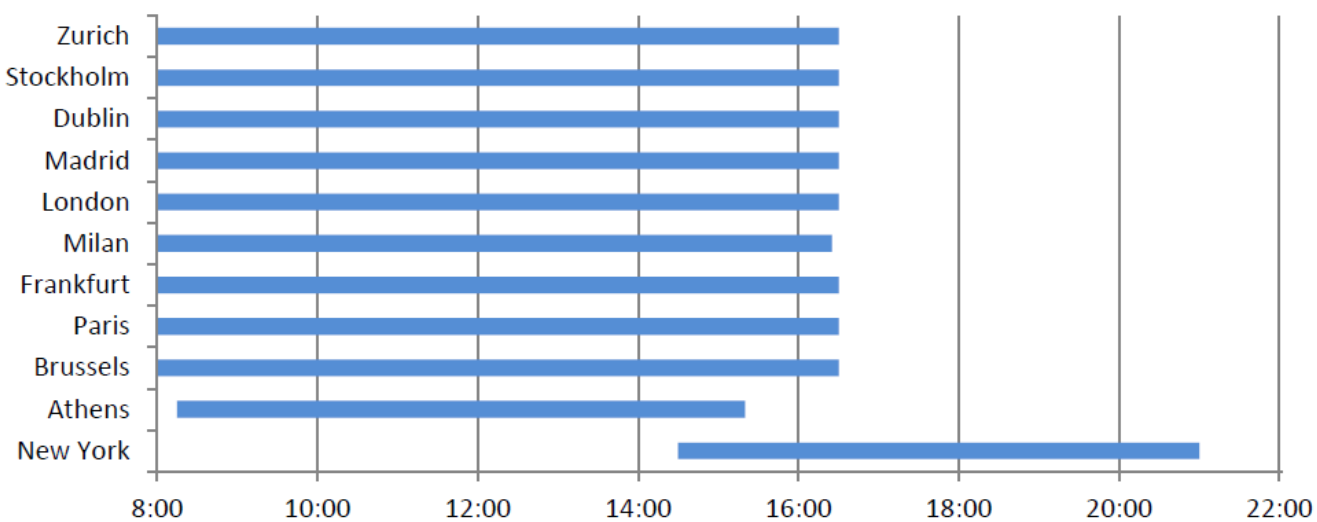


Table 3: Trading hours and consumer confidence index announcement time under Local and London time

Table 3 shows the market open and close times for each market as well as the announcement time (Consumer confidence index announcement time) in both local time and GMT.

\begin{tabular}{|c|c|c|c|c|c|c|}
\hline \multirow[b]{2}{*}{ Market } & \multicolumn{3}{|c|}{ Local Time } & \multicolumn{3}{|c|}{ London Time } \\
\hline & $\begin{array}{l}\text { Opening } \\
\text { Time }\end{array}$ & $\begin{array}{l}\text { Closing } \\
\text { Time }\end{array}$ & $\begin{array}{c}\text { Announcement } \\
\text { Time }\end{array}$ & $\begin{array}{l}\text { Opening } \\
\text { Time }\end{array}$ & $\begin{array}{c}\text { Closing } \\
\text { Time }\end{array}$ & $\begin{array}{c}\text { Announcement } \\
\text { Time } \\
\end{array}$ \\
\hline New York & 09:30 & $16: 00$ & $10: 00$ & $14: 30$ & 21:00 & $15: 00$ \\
\hline Athens & $10: 00$ & $17: 20$ & $17: 00$ & 08:00 & $15: 20$ & $15: 00$ \\
\hline Brussels & 09:00 & $17: 30$ & $16: 00$ & 08:00 & $16: 30$ & $15: 00$ \\
\hline Paris & 09:00 & $17: 30$ & $16: 00$ & 08:00 & $16: 30$ & $15: 00$ \\
\hline Frankfurt & 09:00 & $17: 30$ & $16: 00$ & 08:00 & $16: 30$ & $15: 00$ \\
\hline Milan & 09:00 & $17: 25$ & $16: 00$ & 08:00 & $16: 25$ & $15: 00$ \\
\hline London & 08:00 & $16: 30$ & $15: 00$ & 08:00 & $16: 30$ & $15: 00$ \\
\hline Madrid & 09:00 & $17: 30$ & $16: 00$ & 08:00 & $16: 30$ & $15: 00$ \\
\hline Dublin & 08:00 & $16: 30$ & $15: 00$ & 08:00 & $16: 30$ & $15: 00$ \\
\hline Stockholm & 09:00 & $17: 30$ & $16: 00$ & 08:00 & $16: 30$ & $15: 00$ \\
\hline Zurich & 09:00 & $17: 30$ & $16: 00$ & 08:00 & $16: 30$ & $15: 00$ \\
\hline
\end{tabular}

Figure 2: Financials sector volatility per minute
Figure 3: Healthcare sector volatility per minute

Figures 2 to 4 below presents the minute per minute annualized volatility aggregated for the six consumer confidence index announcements between ten minutes before and thirty minutes after the announcement time. The Garman and Klass (1980) volatility estimator is used to calculate stock volatility. Equally stock weights within a market and industry is considered.

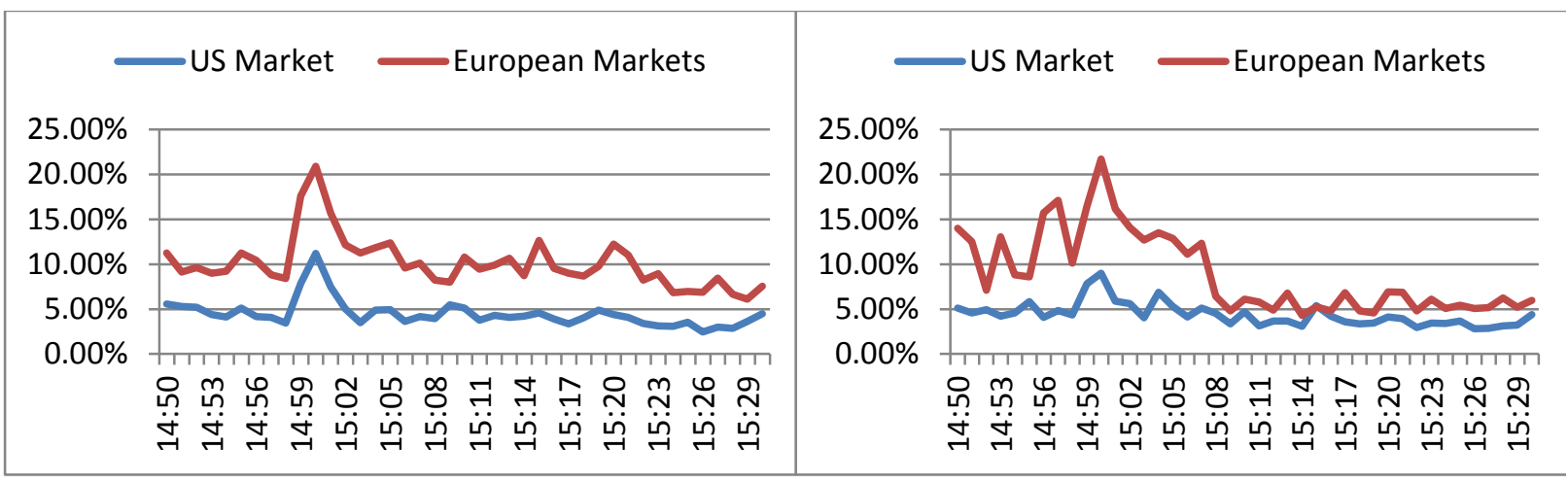

Figure 4: Industrials sector volatility per minute

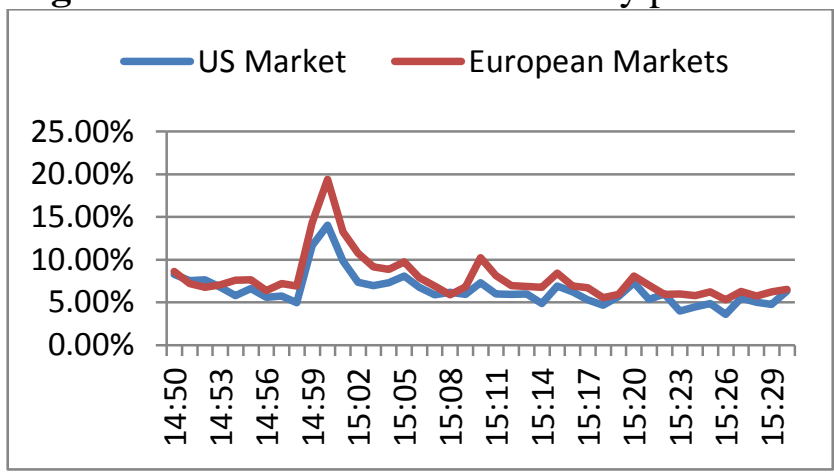




\section{Table 4: US and European stock markets volatility increase per industry}

The sample consists of five minutes interval of increased volatility in the US and European Stock markets after the consumer confidence index announcement. Financials, Healthcare and Industrials are the sectors analyzed. The table shows the percentage and number of five minute interval observations for different levels of increased volatility.

\begin{tabular}{|c|c|c|c|c|c|c|c|c|c|c|c|c|}
\hline \multirow{3}{*}{$\begin{array}{l}\text { Percentage } \\
\text { increase }\end{array}$} & \multicolumn{12}{|c|}{ Sectors } \\
\hline & \multicolumn{4}{|c|}{ Financials } & \multicolumn{5}{|c|}{ Healthcare } & \multicolumn{3}{|c|}{ Industrials } \\
\hline & USA & Obs. & Europe & Obs. & USA & Obs. & Europe & Obs. & USA & Obs. & Europe & Obs \\
\hline Below 30 percent & $0.00 \%$ & 0 & $30.00 \%$ & 18 & $16.67 \%$ & 1 & $41.67 \%$ & 25 & $50.00 \%$ & 3 & $33.33 \%$ & 20 \\
\hline ]30 ; 40] percent & $50.00 \%$ & 3 & $0.00 \%$ & 0 & $0.00 \%$ & 0 & $0.00 \%$ & 0 & $0.00 \%$ & 0 & $5.00 \%$ & 3 \\
\hline ]40; 50] percent & $0.00 \%$ & 0 & $3.33 \%$ & 2 & $16.67 \%$ & 1 & $3.33 \%$ & 2 & $0.00 \%$ & 0 & $3.33 \%$ & 2 \\
\hline $150 ; 60]$ percent & $16.67 \%$ & 1 & $5.00 \%$ & 3 & $33.33 \%$ & 2 & $1.67 \%$ & 1 & $0.00 \%$ & 0 & $5.00 \%$ & 3 \\
\hline Above 60 percent & $33.33 \%$ & 2 & $61.67 \%$ & 37 & $33.33 \%$ & 2 & $53.33 \%$ & 32 & $50.00 \%$ & 3 & $53.33 \%$ & 32 \\
\hline
\end{tabular}

\section{Table 5: Average Volatility for the first five minutes}

Panel A and B shows the average volatility for the US and European markets (respectively) for the first to the fifth minute after the announcement and average for the first five minutes and next 25 minutes. Results are presented for the three sectors (Financials, Healthcare and Industrials). A Wilcoxon rank-sum (Mann-Whitney) test is performed to analyse the statistical difference between values for the two time periods (First five minutes and remaining 25 minutes after the consumer confident index announcement). Statistical significance of volatility is reported. $* * *, * * *$ and denotes significance at the $1 \%, 5 \%$, and $10 \%$ level, respectively.

\section{Panel A: US Market}

\begin{tabular}{|c|c|c|c|c|c|c|c|c|}
\hline \multicolumn{9}{|c|}{ Time in minutes } \\
\hline Average Volatility & $1^{\text {st }}$ minute & $2^{\text {nd }}$ minute & $3^{\text {rd }}$ minute & $4^{\text {th }}$ minute & $5^{\text {th }}$ minute & First 5 minutes & $\begin{array}{l}\text { Remaining } \\
25 \text { minutes }\end{array}$ & Wilcoxon \\
\hline Financials & $11.21 \% * * *$ & $7.44 \% * * *$ & $5.02 \% * * *$ & $3.51 \% * * *$ & $4.90 \% * * *$ & $6.42 \% * * *$ & $3.97 \% * * *$ & $3.716^{* * *}$ \\
\hline Healthcare & $9.06 \% * * *$ & $6.08 \% * * *$ & $5.75 \% * * *$ & $4.51 \% * * *$ & $6.85 \% * *$ & $6.45 \% * * *$ & $4.18 \% * * *$ & $4.234 * * *$ \\
\hline Industrials & $14.05 \% * * *$ & $9.83 \% * * *$ & $7.36 \% * * *$ & $6.99 \% * * *$ & $7.30 \% * * *$ & $9.11 \% * * *$ & $5.80 \% * * *$ & $5.224 * * *$ \\
\hline
\end{tabular}

\section{Panel B: European markets}

\begin{tabular}{|c|c|c|c|c|c|c|c|c|}
\hline \multicolumn{9}{|c|}{ Time in minutes } \\
\hline Average Volatility & $1^{\text {st }}$ minute & $2^{\text {nd }}$ minute & $3^{\text {rd }}$ minute & $4^{\text {th }}$ minute & $5^{\text {th }}$ minute & First 5 minutes & $\begin{array}{l}\text { Remaining } \\
25 \text { minutes }\end{array}$ & Wilcoxon \\
\hline Financials & $20.88 \% * * *$ & $15.67 \% * * *$ & $12.16 \% * * *$ & $11.23 \%$ *** & $11.84 \% * * *$ & $14.36 \% * * *$ & $9.58 \% * * *$ & $2.242 * *$ \\
\hline Healthcare & $20.90 \% * *$ & $14.51 \% * *$ & $13.00 \% * *$ & $11.81 \% *$ & $12.47 \% *$ & $14.54 \% * *$ & $6.49 \% * * *$ & $2.121 * *$ \\
\hline Industrials & $19.39 \% * * *$ & $13.27 \% * * *$ & $10.75 \% * * *$ & $9.16 \% * * *$ & $8.88 \% * * *$ & $12.29 \% * * *$ & $6.98 \% * * *$ & $1.761 *$ \\
\hline
\end{tabular}


Table 6: US and European markets volatility post-announcement

Panel A: Within each market

Panel A shows the average volatility for the US and for each European market per sector (Financials, Healthcare and Industrials) for the first five minutes and the next 25 minutes after the announcement. A Wilcoxon rank-sum (Mann-Whitney) test is performed to analyse the statistical difference between values for the two time periods to each European market and sector. ***,**,* and denotes significance at the $1 \%, 5 \%$, and $10 \%$ level, respectively.

\begin{tabular}{|c|c|c|c|c|c|c|c|c|c|}
\hline & \multicolumn{3}{|c|}{ Financials } & \multicolumn{3}{|c|}{ Healthcare } & \multicolumn{3}{|c|}{ Industrials } \\
\hline $\begin{array}{l}\text { Average } \\
\text { Volatility }\end{array}$ & $\begin{array}{c}\text { First } 5 \\
\text { minutes }\end{array}$ & $\begin{array}{c}\text { Next } \\
25 \text { minutes } \\
\end{array}$ & Wilcoxon & $\begin{array}{c}\text { First } 5 \\
\text { minutes }\end{array}$ & $\begin{array}{c}\text { Next } \\
25 \text { minutes }\end{array}$ & Wilcoxon & $\begin{array}{c}\text { First } 5 \\
\text { minutes }\end{array}$ & $\begin{array}{c}\text { Next } \\
25 \text { minutes }\end{array}$ & Wilcoxon \\
\hline USA & $6.42 \% * * *$ & $3.97 \% * * *$ & $3.716^{* * *}$ & $6.45 \% * * *$ & $4.18 \%$ *** & $4.234 * * *$ & $9.11 \% * * *$ & $5.80 \%$ *** & $5.224 * * *$ \\
\hline Athens & $20.36 \% * * *$ & $1.72 \% * *$ & $8.085^{* * *}$ & $56.38 \% *$ & $11.28 \%$ *** & $2.525 * *$ & $22.00 \% * * *$ & $3.91 \% * * *$ & $7.090 * * *$ \\
\hline Brussels & $8.96 \% * * *$ & $4.07 \% * * *$ & $3.923 * * *$ & $8.94 \% * * *$ & $6.29 \% * * *$ & 0.663 & $14.15 \% * * *$ & $8.77 \% * * *$ & $2.503 * *$ \\
\hline Paris & $18.09 \%$ *** & $13.18 \% * * *$ & $3.002 * * *$ & $15.59 \% * * *$ & $8.02 \% * * *$ & $2.668 * * *$ & $13.49 \% * * *$ & $9.034 \% * * *$ & $2.787 * * *$ \\
\hline Frankfurt & $17.96 \% * * *$ & $11.91 \% * * *$ & $2.034 * *$ & $10.33 \% * * *$ & $6.71 \% * * *$ & $2.837 * * *$ & $14.89 \% * * *$ & $10.93 \% * * *$ & $2.399 * *$ \\
\hline London & $9.28 \% * * *$ & $5.23 \% * * *$ & $2.134 * *$ & $8.08 \%$ *** & $4.88 \%$ *** & $1.681^{*}$ & $10.24 \%$ *** & $4.43 \% * * *$ & $4.502 * * *$ \\
\hline Madrid & $16.85 \%$ *** & $12.45 \% * * *$ & $1.954 *$ & $11.23 \%$ *** & $6.47 \%$ *** & $2.007 * *$ & $12.82 \% * * *$ & $8.68 \%$ *** & 1.524 \\
\hline Dublin & $8.82 \% * * *$ & $14.12 \% * * *$ & $-1.913^{*}$ & $2.66 \% *$ & $5.31 \% * * *$ & $-1.950 * *$ & $4.21 \% * *$ & $3.57 \% * * *$ & -1.474 \\
\hline Milan & $18.11 \% * * *$ & $13.09 \% * * *$ & $2.487 * *$ & $16.53 \% * * *$ & $9.01 \% * * *$ & 1.304 & $11.75 \% * * *$ & $7.67 \% * * *$ & 1.616 \\
\hline Stockholm & $10.65 \% * * *$ & $7.05 \% * * *$ & $2.096^{* *}$ & $7.76 \% * * *$ & $4.08 \% * * *$ & $2.633 * * *$ & $11.63 \% * * *$ & $6.27 \% * * *$ & $3.735 * * *$ \\
\hline Zurich & $14.50 \%$ *** & $9.83 \% * * *$ & $2.004 * *$ & $7.84 \% * * *$ & $4.74 \% * * *$ & $3.510 * * *$ & $7.72 \% * * *$ & $5.34 \% * * *$ & 0.810 \\
\hline
\end{tabular}

\section{Panel B: Across USA and European Markets}

Panel B reports the Wilcoxon rank-sum (Mann-Whitney) test to analyse the statistical difference between the USA market volatility vis-à-vis with European markets volatilities for the first 5and next 25 minutes after the announcement and per sector. ***,**, * and denotes significance at the $1 \%$, 5\%, and $10 \%$ level, respectively.

\begin{tabular}{|c|c|c|c|c|c|c|c|c|}
\hline \multirow[b]{2}{*}{ USA } & \multicolumn{2}{|r|}{ Financials } & \multicolumn{3}{|c|}{ Healthcare } & & \multicolumn{2}{|c|}{ Industrials } \\
\hline & $\begin{array}{l}\text { First } 5 \\
\text { minutes }\end{array}$ & $\begin{array}{c}\text { Next } \\
25 \text { minutes }\end{array}$ & USA & $\begin{array}{l}\text { First } 5 \\
\text { minutes }\end{array}$ & $\begin{array}{c}\text { Next } \\
25 \text { minutes }\end{array}$ & USA & $\begin{array}{l}\text { First } 5 \\
\text { minutes }\end{array}$ & $\begin{array}{c}\text { Next } \\
25 \text { minutes }\end{array}$ \\
\hline Athens & $-3.875 * * *$ & $9.708 * * *$ & Athens & $4.606 * * *$ & $12.398 * * *$ & Athens & $-3.254 * * *$ & $9.952 * * *$ \\
\hline Brussels & -0.547 & $2.722 * * *$ & Brussels & 1.302 & 0.759 & Brussels & -1.020 & -0.068 \\
\hline Paris & $-5.248 * * *$ & $-12.922 * * *$ & Paris & $-2.809 * * *$ & $-8.318 * * *$ & Paris & -1.301 & $-5.975 * * *$ \\
\hline Frankfurt & $-4.494 * * *$ & $-11.687 * * *$ & Frankfurt & $-2.321 * *$ & $-5.249 * * *$ & Frankfurt & $-2.484 * *$ & $-8.382 * * *$ \\
\hline London & -0.458 & $-3.140 * * *$ & London & 0.636 & -0.917 & London & 0.991 & $5.551 * * *$ \\
\hline Madrid & $-4.435^{* * *}$ & $-13.226 * * *$ & Madrid & -0.030 & $2.980 * * *$ & Madrid & 0.237 & $-3.764 * * *$ \\
\hline Dublin & $4.088 * * *$ & $4.982 * * *$ & Dublin & 4.972 & $4.599 * * *$ & Dublin & $4.068 * * *$ & $6.983 * * *$ \\
\hline Milan & $-4.465 * * *$ & $-11.590 * * *$ & Milan & -0.015 & $1.773^{*}$ & Milan & 0.946 & -0.755 \\
\hline Stockholm & -1.493 & $-5.865 * * *$ & Stockholm & 0.503 & $2.236 * *$ & Stockholm & 0.606 & 0.202 \\
\hline Zurich & $-3.134 * * *$ & $-8.719 * * *$ & Zurich & -0.754 & -0.716 & Zurich & $3.223 * * *$ & $5.551 * * *$ \\
\hline
\end{tabular}




\section{Table 7: Volatility Spillover effect in European Equity markets (1)}

The sample consists of 5,220 observations (minute per minute volatility) from 374 stocks belonging to Financials, Healthcare and Industrials industries from US and ten European markets (Athens, Brussels, Paris, Frankfurt, London, Madrid, Dublin, Milan, Stockholm and Zurich) for the period January to June 2011. The following regression is estimated:

$$
G K e_{m, i, t+1}=\alpha+\beta_{1} G K e_{-} U S_{i, t}+\sum_{k=1}^{L} \beta_{2, k}\left(G K e_{-} U S_{i, t} \times D_{m, k, t}\right)+\varepsilon_{m, i, t}
$$

Where GKe represents the minute per minute volatility starting one minute after the consumer confidence index announcement and calculated for the next 30 minutes after the announcement for each $\mathrm{m}^{\text {th }}$ European market and $\mathrm{i}^{\text {th }}$ sector index on the $\mathrm{t}^{\text {th }}$ minute. $\alpha$ is the constant term. GKe US is the volatility for each $\mathrm{i}^{\text {th }}$ US sector index starting in the minute of the consumer confidence index announcement and calculated for the next 30 minutes after the announcement. $D_{m, k, t}$ are binary variables to control for sectors (Healthcare and Industrials) and whether volatility increase in the US market is above 30, 40, 50 and 60 percent. $\varepsilon_{m, i, t}$ is the error term. ***, **, * and denotes significance at the $1 \%, 5 \%$, and $10 \%$ level, respectively. T-statistics are reported in parenthesis.

\begin{tabular}{|c|c|c|c|c|c|c|}
\hline & Model 1 & Model 2 & Model 3 & Model 4 & Model 5 & Model 6 \\
\hline GKe_US & $\begin{array}{c}0.536 * * * \\
(7.120)\end{array}$ & $\begin{array}{c}1.010 * * * \\
(10.52)\end{array}$ & $\begin{array}{c}1.028 * * * \\
(7.44)\end{array}$ & $\begin{array}{c}0.983 * * * \\
(8.43)\end{array}$ & $\begin{array}{c}0.950 * * * \\
(8.06)\end{array}$ & $\begin{array}{c}0.875 * * * \\
(7.35)\end{array}$ \\
\hline GKe_US $\times$ Healthcare & & $\begin{array}{c}-0.621 * * * \\
(-6.02)\end{array}$ & $\begin{array}{c}-0.607 * * * \\
(-5.80)\end{array}$ & $\begin{array}{c}-0.658 * * * \\
(-6.30)\end{array}$ & $\begin{array}{c}-0.649 * * * \\
(-6.26)\end{array}$ & $\begin{array}{c}-0.571 * * * \\
(-5.50)\end{array}$ \\
\hline GKe_US $\times$ Industrials & & $\begin{array}{c}-0.685 * * * \\
(-7.47)\end{array}$ & $\begin{array}{c}-0.649 * * * \\
(-6.35)\end{array}$ & $\begin{array}{l}-0.665 \\
(-7.23)\end{array}$ & $\begin{array}{c}-0.658 * * * \\
(-7.16)\end{array}$ & $\begin{array}{c}-0.650 * * * \\
(-7.08)\end{array}$ \\
\hline GKe_US $\times 30$ percent & & & $\begin{array}{c}0.0734 \\
(0.80)\end{array}$ & & & \\
\hline GKe_US $\times 40$ percent & & & & $\begin{array}{c}0.176 * * \\
(2.25)\end{array}$ & & \\
\hline GKe_US $\times 50$ percent & & & & & $\begin{array}{c}0.210 * * * \\
(2.74)\end{array}$ & \\
\hline GKe_US $\times 60$ percent & & & & & & $\begin{array}{c}0.297 * * * \\
(3.93)\end{array}$ \\
\hline Constant & $\begin{array}{c}0.059 * * * \\
(13.100)\end{array}$ & $\begin{array}{c}0.0543 * * * \\
(11.68)\end{array}$ & $\begin{array}{c}0.054 * * * \\
(11.65)\end{array}$ & $\begin{array}{c}0.055^{* * * *} \\
(11.80)\end{array}$ & $\begin{array}{c}0.056 * * * \\
(11.92)\end{array}$ & $\begin{array}{c}0.058 * * * \\
(12.21)\end{array}$ \\
\hline $\begin{array}{l}\text { Observations } \\
\text { Adi R-squared }\end{array}$ & 5,220 & 5,220 & 5,220 & 5,220 & 5,220 & 5,220 \\
\hline Adj R-squared & 0.009 & 0.021 & 0.020 & 0.021 & 0.022 & 0.023 \\
\hline
\end{tabular}




\section{Table 8: Volatility Spillover effect in European Equity markets (2)}

The sample consists initially of 5,220 observations (minute per minute volatility) from 374 stocks belonging to Financials, Healthcare and Industrials sectors from US and ten European markets (Athens, Brussels, Paris, Frankfurt, London, Madrid, Dublin, Milan, Stockholm and Zurich) for the period January to June 2011. The following regression is estimated:

$$
G K e_{m, i, t+n}=\alpha+\beta_{1} G K e_{-} U S_{i, t}+\sum_{k=1}^{L} \beta_{2, k}\left(G K e_{-} U S_{i, t} \times D_{m, k, t}\right)+\varepsilon_{m, i, t}
$$

Where $G K e$ represents the minute per minute volatility starting from 1 to 5 minutes after the consumer confidence index announcement and calculated for the next 30 minutes after the announcement for each $\mathrm{m}^{\text {th }}$ European market and $\mathrm{i}^{\text {th }}$ sector index on the $\mathrm{t}^{\text {th }}$ minute, with $\mathrm{n}$ assuming the values of 1 to 5 . $\alpha$ is the constant term. GKe US is the volatility for each $\mathrm{i}^{\text {th }}$ US sector index starting in the minute of the consumer confidence index announcement and calculated for the next 30 minutes after the announcement. $D_{m, k, t}$ are binary variables to control for sectors (Healthcare and Industrials) and whether volatility increase in the US market is above $30,40,50$ and 60 percent (the model is estimated using one of the volatility increase binary variables at a time). $\varepsilon_{m, i, t}$ is the error term. $* * *, * *, *$ and denotes significance at the $1 \%, 5 \%$, and $10 \%$ level, respectively. T-statistics are reported in parenthesis.

Panel A: Volatility increase of 40 percent in the US market

\begin{tabular}{|c|c|c|c|c|c|}
\hline Variables & $\begin{array}{l}\text { European } \\
\text { markets }_{\mathrm{t}+1}\end{array}$ & $\begin{array}{l}\text { European } \\
\text { markets }_{\mathrm{t}+2}\end{array}$ & $\begin{array}{l}\text { European } \\
\text { markets }_{\mathrm{t}+3}\end{array}$ & $\begin{array}{l}\text { European } \\
\text { markets }_{\mathrm{t}+4}\end{array}$ & $\begin{array}{l}\text { European } \\
\text { markets }_{\mathrm{t}+5}\end{array}$ \\
\hline$G K e_{-} U S$ & $\begin{array}{c}0.983 * * * \\
(8.43)\end{array}$ & $\begin{array}{c}0.627 * * * \\
(5.62)\end{array}$ & $\begin{array}{c}0.503 * * * \\
(4.67)\end{array}$ & $\begin{array}{c}0.474 * * * \\
(4.57)\end{array}$ & $\begin{array}{c}0.615 * * * \\
(6.24)\end{array}$ \\
\hline GKe_US $\times$ Healthcare & $\begin{array}{c}-0.658 * * * \\
(-6.30)\end{array}$ & $\begin{array}{c}-0.621 * * * \\
(-6.21)\end{array}$ & $\begin{array}{c}-0.596 * * * \\
(-6.17)\end{array}$ & $\begin{array}{c}-0.623 * * * \\
(-6.73)\end{array}$ & $\begin{array}{c}-0.638 * * * \\
(-7.24)\end{array}$ \\
\hline GKe_US $\times$ Industrials & $\begin{array}{c}-0.665 * * * \\
(-7.23)\end{array}$ & $\begin{array}{c}-0.566 * * * \\
(-6.43)\end{array}$ & $\begin{array}{c}-0.517 * * * \\
(-6.08)\end{array}$ & $\begin{array}{c}-0.506^{* * * *} \\
(-6.21)\end{array}$ & $\begin{array}{c}-0.554 * * * \\
(-7.14)\end{array}$ \\
\hline GKe_US $\times 40$ percent & $\begin{array}{c}0.176^{* * *} \\
(2.25)\end{array}$ & $\begin{array}{c}0.205^{* * *} * \\
(2.74)\end{array}$ & $\begin{array}{c}0.217 * * * \\
(3.00)\end{array}$ & $\begin{array}{c}0.238 * * * \\
(3.42)\end{array}$ & $\begin{array}{c}0.253 * * * \\
(3.82)\end{array}$ \\
\hline Constant & $\begin{array}{c}0.055 * * * \\
(11.80)\end{array}$ & $\begin{array}{c}0.066^{* * *} * \\
(14.55)\end{array}$ & $\begin{array}{c}0.068 \\
(15.42)\end{array}$ & $\begin{array}{c}0.067 * * * \\
(15.61)\end{array}$ & $\begin{array}{c}0.059 * * * \\
(14.33)\end{array}$ \\
\hline Observations & 5,220 & 5,040 & 4,860 & 4,680 & 4,500 \\
\hline Adj. R-Squared & 0.0213 & 0.0137 & 0.0124 & 0.0144 & 0.0216 \\
\hline
\end{tabular}


Panel B: Volatility Increase Coefficients

\begin{tabular}{lccccc}
\hline Variables & $\begin{array}{c}\text { European } \\
\text { markets }_{\mathrm{t}+1}\end{array}$ & $\begin{array}{c}\text { European } \\
\text { markets }_{\mathrm{t}+2}\end{array}$ & $\begin{array}{c}\text { European } \\
\text { markets }_{\mathrm{t}+3}\end{array}$ & $\begin{array}{c}\text { European } \\
\text { markets }_{\mathrm{t}+4}\end{array}$ & $\begin{array}{c}\text { European } \\
\text { markets }_{\mathrm{t}+5}\end{array}$ \\
\hline GKe_US $\times 30$ percent & 0.073 & 0.114 & 0.136 & 0.136 & $0.148^{*}$ \\
& $(0.80)$ & $(1.29)$ & $(1.59)$ & $(1.66)$ & $(1.90)$ \\
GKe_US $\times 40$ percent & $0.176^{* *}$ & $0.205^{* * *}$ & $0.217 * * *$ & $0.238^{* * *}$ & $0.253^{* * *}$ \\
& $(2.25)$ & $(2.74)$ & $(3.00)$ & $(3.42)$ & $(3.82)$ \\
GKe_US $\times 50$ percent & $0.210^{* * *}$ & $0.240^{* * *}$ & $0.250^{* * *}$ & $0.270^{* * *}$ & $0.278^{* * *}$ \\
& $(2.74)$ & $(3.26)$ & $(3.52)$ & $(3.96)$ & $(4.28)$ \\
GKe_US $\times 60$ percent & $0.297 * * *$ & $0.309 * * *$ & $0.308^{* * *}$ & $0.333^{* * *}$ & $0.334^{* * *}$ \\
& $(3.93)$ & $(4.27)$ & $(4.40)$ & $(4.96)$ & $(5.22)$ \\
\hline
\end{tabular}




\section{Table 9: Volatility Spillover effect in European Equity markets (3)}

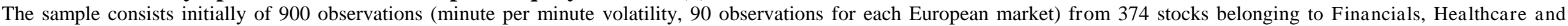

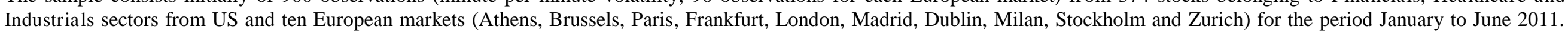
The following regression is estimated:

$$
G K e_{m, i, t+1}=\alpha+\sum_{k=1}^{L} \beta_{1, k}\left(G K e_{-} U S_{i, t} \times D_{m, k, t}\right)+\varepsilon_{m, i, t}
$$

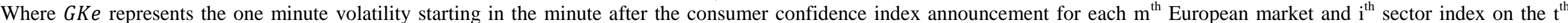

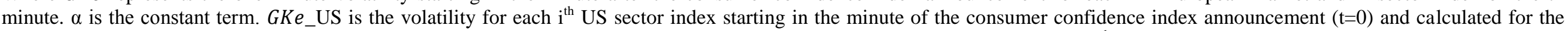

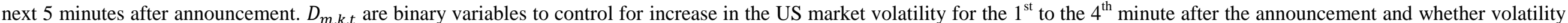

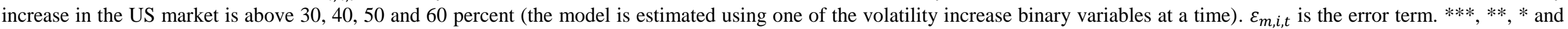
denotes significance at the $1 \%, 5 \%$, and $10 \%$ level, respectively. T-statistics are reported in parenthesis.

\begin{tabular}{|c|c|c|c|c|c|c|c|c|c|c|c|}
\hline Variables & $\begin{array}{c}\text { European } \\
\text { Markets }\end{array}$ & Athens & Brussels & Paris & Frankfurt & London & Madrid & Dublin & Milan & Stockholm & Zurich \\
\hline $\mathrm{GKe} \_\mathrm{US} \times 1^{\mathrm{st}}$ minute & $\begin{array}{c}0.837 * * * \\
(3.19)\end{array}$ & $\begin{array}{l}2.217 \\
(1.01)\end{array}$ & $\begin{array}{l}0.357 \\
(1.05)\end{array}$ & $\begin{array}{c}0.637 * \\
(1.74)\end{array}$ & $\begin{array}{c}1.226^{* * * *} \\
(3.67)\end{array}$ & $\begin{array}{c}0.759 * * * \\
(3.40)\end{array}$ & $\begin{array}{c}1.268 * * * \\
(3.19)\end{array}$ & $\begin{array}{l}-0.134 \\
(-0.36)\end{array}$ & $\begin{array}{l}0.357 \\
(0.68)\end{array}$ & $\begin{array}{c}0.819 * * * \\
(3.15)\end{array}$ & $\begin{array}{l}0.862 \\
(2.91)\end{array}$ \\
\hline $\mathrm{GKe} \_\mathrm{US} \times 2^{\text {nd }}$ minute & $\begin{array}{c}-0.744^{*} \\
(-1.73)\end{array}$ & $\begin{array}{c}-7.363 * * \\
(-2.05)\end{array}$ & $\begin{array}{c}1.599 * * * \\
(2.86)\end{array}$ & $\begin{array}{l}-0.284 \\
(-0.47)\end{array}$ & $\begin{array}{l}0.139 \\
(0.25)\end{array}$ & $\begin{array}{l}-0.297 \\
(-0.81)\end{array}$ & $\begin{array}{l}-0.518 \\
(-0.79)\end{array}$ & $\begin{array}{l}0.748 \\
(1.22)\end{array}$ & $\begin{array}{l}-0.888 \\
(-1.04)\end{array}$ & $\begin{array}{l}-0.051 \\
(-0.12)\end{array}$ & $\begin{array}{l}-0.524 \\
(-1.08)\end{array}$ \\
\hline GKe_US $\times 3^{\text {rd }}$ minute & $\begin{array}{c}0.676^{* *} \\
(1.96)\end{array}$ & $\begin{array}{c}8.627 * * * \\
(2.98)\end{array}$ & $\begin{array}{l}0.348 \\
(0.77)\end{array}$ & $\begin{array}{l}-0.585 \\
(-1.21)\end{array}$ & $\begin{array}{l}-0.120 \\
(-0.27)\end{array}$ & $\begin{array}{l}-0.416 \\
(-1.41)\end{array}$ & $\begin{array}{l}0.194 \\
(0.37)\end{array}$ & $\begin{array}{c}-0.839 * \\
(-1.69)\end{array}$ & $\begin{array}{l}-0.174 \\
(-0.25)\end{array}$ & $\begin{array}{l}-0.107 \\
(-0.31)\end{array}$ & $\begin{array}{l}-0.167 \\
(-0.43)\end{array}$ \\
\hline $\mathrm{GKe}-\mathrm{US} \times 4^{\text {th }}$ minute & $\begin{array}{c}-0.500 * * \\
(-2.15)\end{array}$ & $\begin{array}{l}-2.664 \\
(-1.37)\end{array}$ & $\begin{array}{l}-0.010 \\
(-0.03)\end{array}$ & $\begin{array}{l}-0.351 \\
(-1.08)\end{array}$ & $\begin{array}{c}-0.649 * * \\
(-2.19)\end{array}$ & $\begin{array}{l}-0.256 \\
(-1.29)\end{array}$ & $\begin{array}{c}-0.723 * * \\
(-2.05)\end{array}$ & $\begin{array}{l}-0.143 \\
(-0.43)\end{array}$ & $\begin{array}{l}0.768 \\
(1.65)\end{array}$ & $\begin{array}{l}-0.225 \\
(-0.97)\end{array}$ & $\begin{array}{c}-0.749 * * * \\
(-2.85)\end{array}$ \\
\hline GKe_US $\times 40$ percent & $\begin{array}{c}0.384^{* *} \\
(1.97)\end{array}$ & $\begin{array}{l}-0.386 \\
(-0.23)\end{array}$ & $\begin{array}{l}-0.044 \\
(-0.17)\end{array}$ & $\begin{array}{c}1.054^{* * * *} \\
(4.20)\end{array}$ & $\begin{array}{l}0.339 \\
(1.36)\end{array}$ & $\begin{array}{c}0.447 * * * \\
(2.79)\end{array}$ & $\begin{array}{c}0.935^{* * *} \\
(3.33)\end{array}$ & $\begin{array}{l}-0.286 \\
(-1.02)\end{array}$ & $\begin{array}{c}0.864^{* *} \\
(2.26)\end{array}$ & $\begin{array}{c}0.549 * * * \\
(2.95)\end{array}$ & $\begin{array}{c}0.368^{*} \\
(1.68)\end{array}$ \\
\hline Constant & $\begin{array}{c}0.099 * * * \\
(5.24)\end{array}$ & $\begin{array}{l}0.235 \\
(1.49)\end{array}$ & $\begin{array}{c}0.061^{* *} \\
(2.50)\end{array}$ & $\begin{array}{c}0.140 * * * \\
(5.29)\end{array}$ & $\begin{array}{c}0.087 * * * \\
(3.62)\end{array}$ & $\begin{array}{c}0.061 * * * \\
(3.79)\end{array}$ & $\begin{array}{c}0.082 * * * \\
(2.87)\end{array}$ & $\begin{array}{c}0.070^{* *} \\
(2.60)\end{array}$ & $\begin{array}{c}0.116^{* * * *} \\
(3.09)\end{array}$ & $\begin{array}{c}0.057 * * * \\
(3.03)\end{array}$ & $\begin{array}{c}0.079 * * * \\
(3.69)\end{array}$ \\
\hline $\begin{array}{l}\text { Observations } \\
\text { Adj. R-Squared }\end{array}$ & $\begin{array}{c}900 \\
0.0151\end{array}$ & $\begin{array}{c}90 \\
0.0952\end{array}$ & $\begin{array}{c}90 \\
0.0781\end{array}$ & $\begin{array}{c}90 \\
0.0448\end{array}$ & $\begin{array}{c}90 \\
0.1144\end{array}$ & $\begin{array}{c}90 \\
0.2058\end{array}$ & $\begin{array}{c}90 \\
0.0976\end{array}$ & $\begin{array}{c}90 \\
0.003\end{array}$ & $\begin{array}{c}90 \\
0.1008\end{array}$ & $\begin{array}{c}90 \\
0.1178\end{array}$ & $\begin{array}{c}90 \\
0.1095\end{array}$ \\
\hline
\end{tabular}


Panel B: Volatility Increase Coefficients

\begin{tabular}{|c|c|c|c|c|c|c|c|c|c|c|c|}
\hline Variables & $\begin{array}{c}\text { European } \\
\text { Markets }\end{array}$ & Athens & Brussels & Paris & Frankfurt & London & Madrid & Dublin & Milan & Stockholm & Zurich \\
\hline GKe_US $\times 30$ percent & $\begin{array}{c}0.257 \\
(1.25)\end{array}$ & $\begin{array}{l}-1.640 \\
(-0.96)\end{array}$ & $\begin{array}{l}-0.304 \\
(-1.14)\end{array}$ & $\begin{array}{c}1.013 * * * \\
(3.80)\end{array}$ & $\begin{array}{c}0.487 * \\
(1.89)\end{array}$ & $\begin{array}{c}0.499 * * * \\
(2.99)\end{array}$ & $\begin{array}{c}0.988 * * * \\
(3.36)\end{array}$ & $\begin{array}{c}-0.551 * \\
(-1.91)\end{array}$ & $\begin{array}{c}1.120 * * * \\
(2.85)\end{array}$ & $\begin{array}{c}0.511 * * \\
(2.59)\end{array}$ & $\begin{array}{l}0.444 \\
(1.95)\end{array}$ \\
\hline GKe_US $\times 40$ percent & $\begin{array}{c}0.384 * * \\
(1.97)\end{array}$ & $\begin{array}{l}-0.386 \\
(-0.23)\end{array}$ & $\begin{array}{l}-0.044 \\
(-0.17)\end{array}$ & $\begin{array}{c}1.054 * * * \\
(4.20)\end{array}$ & $\begin{array}{l}0.339 \\
(1.36)\end{array}$ & $\begin{array}{c}0.447 * * * \\
(2.79)\end{array}$ & $\begin{array}{c}0.935 * * * \\
(3.33)\end{array}$ & $\begin{array}{l}-0.286 \\
(-1.02)\end{array}$ & $\begin{array}{c}0.864 * * \\
(2.26)\end{array}$ & $\begin{array}{c}0.549 * * * \\
(2.95)\end{array}$ & $\begin{array}{c}0.368 * \\
(1.68)\end{array}$ \\
\hline GKe_US $\times 50$ percent & $\begin{array}{c}0.400 * * \\
(2.09)\end{array}$ & $\begin{array}{l}-0.457 \\
(-0.28)\end{array}$ & $\begin{array}{l}-0.052 \\
(-0.21)\end{array}$ & $\begin{array}{l}1.095 \\
(4.52)\end{array}$ & $\begin{array}{l}0.347 \\
(1.43)\end{array}$ & $\begin{array}{c}0.452 * * * \\
(2.89)\end{array}$ & $\begin{array}{c}0.936 * * * \\
(3.41)\end{array}$ & $\begin{array}{l}-0.187 \\
(-0.68)\end{array}$ & $\begin{array}{c}0.944 * * \\
(2.54)\end{array}$ & $\begin{array}{c}0.539 * * * \\
(2.96)\end{array}$ & $\begin{array}{c}0.382 * \\
(1.78)\end{array}$ \\
\hline GKe_US $\times 60$ percent & $\begin{array}{c}0.487 * * * \\
(2.61)\end{array}$ & $\begin{array}{l}1.098 \\
(0.70)\end{array}$ & $\begin{array}{l}0.152 \\
(0.62)\end{array}$ & $\begin{array}{c}1.051^{* * *} \\
(4.44)\end{array}$ & $\begin{array}{c}0.433^{*} \\
(1.84)\end{array}$ & $\begin{array}{c}0.352 * * \\
(2.27)\end{array}$ & $\begin{array}{c}0.957 * * * \\
(3.61)\end{array}$ & $\begin{array}{l}-0.394 \\
(-1.49) \\
\end{array}$ & $\begin{array}{l}0.194 \\
(0.52)\end{array}$ & $\begin{array}{c}0.639 * * * \\
(3.69)\end{array}$ & $\begin{array}{c}0.386^{*} \\
(1.85)\end{array}$ \\
\hline
\end{tabular}


Table 10: Volatility Spillover effect in European Equity markets (4)

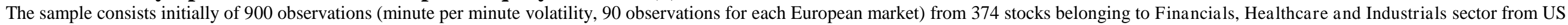
and ten European markets (Athens, Brussels, Paris, Frankfurt, London, Madrid, Dublin, Milan, Stockholm and Zurich) for the period January to June 2011. The following regression is estimated:

$$
G K e_{m, i, t+1}=\alpha+\beta_{1} G K e_{-} U S_{i, t}+\sum_{k=1}^{L} \beta_{2, k} D_{m, k, t}+\varepsilon_{m, i, t}
$$

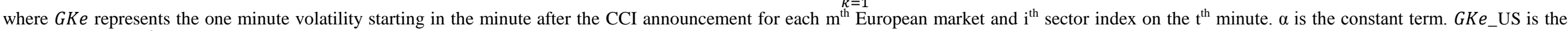

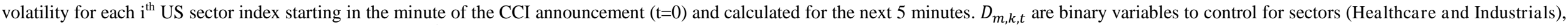

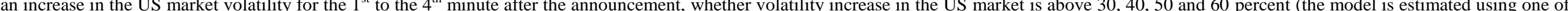

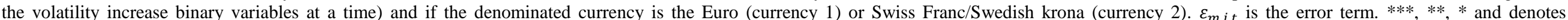
significance at the $1 \%, 5 \%$, and $10 \%$ level, respectively. T-statistics are reported in parenthesis.

\begin{tabular}{|c|c|c|c|c|c|c|c|c|c|c|c|c|}
\hline Variables & $\begin{array}{r}\text { Europea } \\
\text { Markets }\end{array}$ & $\begin{array}{c}\text { European } \\
\text { Markets }\end{array}$ & Athens & Brussels & Paris & Frankfurt & London & Madrid & Dublin & Milan & Stockholn & Zurich \\
\hline$G K e_{-} U S$ & $\begin{array}{c}0.718 * * * \\
(2.98)\end{array}$ & $\begin{array}{c}0.689 * * * \\
(2.98)\end{array}$ & $\begin{array}{l}0.948 \\
(0.63)\end{array}$ & $\begin{array}{l}0.278 \\
(0.96)\end{array}$ & $\begin{array}{c}1.201 * * * \\
(3.92)\end{array}$ & $\begin{array}{c}0.783 * * \\
(2.50)\end{array}$ & $\begin{array}{c}0.712 * * * \\
(3.62)\end{array}$ & $\begin{array}{c}1.334 * * * \\
(3.90)\end{array}$ & $\begin{array}{l}-0.195 \\
(-0.61)\end{array}$ & $\begin{array}{l}0.848 * \\
(1.87)\end{array}$ & $\begin{array}{c}0.819 * * * \\
(3.46)\end{array}$ & $\begin{array}{l}0.453 \\
(1.65)\end{array}$ \\
\hline $1^{\text {st }}$ minute & $\begin{array}{c}0.201 * * * \\
(5.67)\end{array}$ & $\begin{array}{c}0.173 * * * \\
(5.52)\end{array}$ & $\begin{array}{c}1.704 * * * \\
(7.72)\end{array}$ & $\begin{array}{c}0.103^{* *} \\
(2.19)\end{array}$ & $\begin{array}{l}-0.022 \\
(-0.49)\end{array}$ & $\begin{array}{l}0.059 \\
(1.29)\end{array}$ & $\begin{array}{c}0.0183 \\
(0.64)\end{array}$ & $\begin{array}{l}0.006 \\
(0.11)\end{array}$ & $\begin{array}{c}0.100 * * \\
(2.13)\end{array}$ & $\begin{array}{l}-0.015 \\
(-0.23)\end{array}$ & $\begin{array}{l}0.028 \\
(0.81)\end{array}$ & $\begin{array}{l}0.026 \\
(0.65)\end{array}$ \\
\hline $2^{\text {nd }}$ minute & $\begin{array}{l}-0.036 \\
(-1.48)\end{array}$ & $\begin{array}{c}-0.044^{*} \\
(-1.90)\end{array}$ & $\begin{array}{l}-0.160 \\
(-1.04)\end{array}$ & $\begin{array}{c}0.073^{* *} \\
(2.23)\end{array}$ & $\begin{array}{l}-0.040 \\
(-1.26)\end{array}$ & $\begin{array}{l}-0.028 \\
(-0.88)\end{array}$ & $\begin{array}{c}-0.049 * * \\
(-2.44)\end{array}$ & $\begin{array}{c}-0.065 * * \\
(-1.88)\end{array}$ & $\begin{array}{c}0.077 * * \\
(2.36)\end{array}$ & $\begin{array}{c}-0.090^{*} \\
(-1.95)\end{array}$ & $\begin{array}{l}-0.035 \\
(-1.45)\end{array}$ & $\begin{array}{c}-0.048^{*} \\
(-1.73)\end{array}$ \\
\hline $3^{\text {rd }}$ minute & $\begin{array}{c}0.066^{* *} \\
(2.48)\end{array}$ & $\begin{array}{c}0.070^{* * * *} \\
(2.66)\end{array}$ & $\begin{array}{c}0.957 * * * \\
(5.77)\end{array}$ & $\begin{array}{l}0.044 \\
(1.25)\end{array}$ & $\begin{array}{c}- \\
0.084 * * * \\
(-2.49)\end{array}$ & $\begin{array}{l}-0.018 \\
(-0.53)\end{array}$ & $\begin{array}{c}-0.067 * * * \\
(-3.10)\end{array}$ & $\begin{array}{l}-0.056 \\
(-1.50)\end{array}$ & $\begin{array}{l}-0.042 \\
(-1.20)\end{array}$ & $\begin{array}{l}-0.027 \\
(-0.55)\end{array}$ & $\begin{array}{l}-0.022 \\
(-0.86)\end{array}$ & $\begin{array}{l}-0.025 \\
(-0.82)\end{array}$ \\
\hline $4^{\text {th }}$ minute & $\begin{array}{c}-0.109 * * * \\
(-3.94)\end{array}$ & $\begin{array}{c}-0.088 * * * \\
(-3.81)\end{array}$ & $\begin{array}{c}-0.774 * * * \\
(-4.49)\end{array}$ & $\begin{array}{l}-0.047 \\
(-1.29)\end{array}$ & $\begin{array}{l}-0.051 \\
(-1.47)\end{array}$ & $\begin{array}{l}-0.057 \\
(-1.59)\end{array}$ & $\begin{array}{c}-0.038^{*} \\
(-1.70)\end{array}$ & $\begin{array}{c}-0.082 * * \\
(-2.11)\end{array}$ & $\begin{array}{c}-0.093 * * \\
(-2.53)\end{array}$ & $\begin{array}{c}0.136^{* *} \\
(2.62)\end{array}$ & $\begin{array}{l}-0.040 \\
(-1.46)\end{array}$ & $\begin{array}{l}-0.044 \\
(-1.39)\end{array}$ \\
\hline 40 percent & $\begin{array}{c}0.091 * * * \\
(3.95)\end{array}$ & $\begin{array}{c}0.087 * * * \\
(4.04)\end{array}$ & $\begin{array}{c}0.570 * * * \\
(3.95)\end{array}$ & $\begin{array}{l}0.033 \\
(1.05)\end{array}$ & $\begin{array}{l}0.042 \\
(1.42)\end{array}$ & $\begin{array}{l}0.037 \\
(1.24)\end{array}$ & $\begin{array}{l}0.024 \\
(1.25)\end{array}$ & $\begin{array}{l}0.042 \\
(1.29)\end{array}$ & $\begin{array}{c}0.076 * * \\
(2.48)\end{array}$ & $\begin{array}{l}0.046 \\
(1.05)\end{array}$ & $\begin{array}{l}0.038^{*} \\
(1.68)\end{array}$ & $\begin{array}{c}0.0079 \\
(0.30)\end{array}$ \\
\hline Healthcare & $\begin{array}{l}0.042 \\
(1.59)\end{array}$ & --- & $\begin{array}{c}0.684 * * * \\
(4.19)\end{array}$ & $\begin{array}{l}0.037 \\
(1.06)\end{array}$ & $\begin{array}{l}-0.026 \\
(-0.79)\end{array}$ & $\begin{array}{c}-0.058^{*} \\
(-1.72)\end{array}$ & $\begin{array}{l}-0.002 \\
(-0.09)\end{array}$ & $\begin{array}{l}-0.052 \\
(-1.40)\end{array}$ & $\begin{array}{l}-0.019 \\
(-0.54)\end{array}$ & $\begin{array}{l}-0.066 \\
(-1.35)\end{array}$ & $\begin{array}{l}-0.025 \\
(-0.97)\end{array}$ & $\begin{array}{c}-0.056^{*} \\
(-1.87)\end{array}$ \\
\hline Industrials & $\begin{array}{l}0.040 \\
(1.42)\end{array}$ & --- & $\begin{array}{c}0.633 * * * \\
(3.61)\end{array}$ & $\begin{array}{c}0.097 * * \\
(2.58)\end{array}$ & $\begin{array}{c}-0.066^{*} \\
(-1.85)\end{array}$ & $\begin{array}{l}-0.020 \\
(-0.55)\end{array}$ & $\begin{array}{l}0.003 \\
(0.11)\end{array}$ & $\begin{array}{l}-0.049 \\
(1.26)\end{array}$ & $\begin{array}{l}0.036 \\
(0.96)\end{array}$ & $\begin{array}{c}-0.174 * * * \\
(-3.31)\end{array}$ & $\begin{array}{l}0.004 \\
(0.15)\end{array}$ & $\begin{array}{c}-0.0631^{*} \\
(-1.97)\end{array}$ \\
\hline Currency 1 & --- & $\begin{array}{c}0.062 * * \\
(3.09)\end{array}$ & --- & --- & -- & --- & --- & --- & --- & --- & --- & --- \\
\hline Currency 2 & --- & $\begin{array}{l}0.008 \\
(0.24)\end{array}$ & --- & --- & --- & --- & --- & --- & --- & --- & --- & --- \\
\hline Constant & $\begin{array}{c}-0.134 * * \\
(-2.56)\end{array}$ & $\begin{array}{c}-0.131 * * \\
(-2.54)\end{array}$ & $\begin{array}{c}-1.829 * * * \\
(-5.60)\end{array}$ & $\begin{array}{l}-0.073 \\
(-1.05)\end{array}$ & $\begin{array}{c}0.134 * * \\
(2.01)\end{array}$ & $\begin{array}{l}0.069 \\
(1.01)\end{array}$ & $\begin{array}{l}0.046 \\
(1.09)\end{array}$ & $\begin{array}{l}0.093 \\
(1.26)\end{array}$ & $\begin{array}{l}-0.039 \\
(-0.57)\end{array}$ & $\begin{array}{l}0.126 \\
(1.28)\end{array}$ & $\begin{array}{l}0.024 \\
(0.47)\end{array}$ & $\begin{array}{l}0.111^{*} \\
(1.86)\end{array}$ \\
\hline Observations & 900 & 900 & 90 & 90 & 90 & 90 & 90 & 90 & 90 & 90 & 90 & 90 \\
\hline Adj. R-Squarec & 0.0464 & 0.0523 & 0.5146 & 0.0674 & 0.2428 & 0.1132 & 0.2976 & 0.2422 & 0.1676 & 0.2329 & 0.1731 & 0.1286 \\
\hline
\end{tabular}


Panel B: Volatility Increase Coefficients

\begin{tabular}{|c|c|c|c|c|c|c|c|c|c|c|c|c|}
\hline Variables & $\begin{array}{r}\text { Europe: } \\
\text { Market }\end{array}$ & $\begin{array}{c}\text { European } \\
\text { Markets }\end{array}$ & Athen & Brussels & Paris & Frankfurt & London & Madrid & Dublin & Milan & Stockholn & Zurich \\
\hline 30 percent & $\begin{array}{c}0.094 * * * \\
(2.94)\end{array}$ & $\begin{array}{c}0.048 * * \\
(2.01)\end{array}$ & $\begin{array}{c}0.603 * * * \\
(2.94)\end{array}$ & $\begin{array}{l}0.023 \\
(0.55)\end{array}$ & $\begin{array}{l}0.042 \\
(1.03)\end{array}$ & $\begin{array}{l}0.055 \\
(1.35)\end{array}$ & $\begin{array}{c}0.057 * * \\
(2.25)\end{array}$ & $\begin{array}{l}0.056 \\
(1.24)\end{array}$ & $\begin{array}{l}-0.034 \\
(-0.79)\end{array}$ & $\begin{array}{l}0.078 \\
(1.32)\end{array}$ & $\begin{array}{l}0.044 \\
(1.43)\end{array}$ & $\begin{array}{l}0.012 \\
(0.33)\end{array}$ \\
\hline 40 percent & $\begin{array}{c}0.091 * * * \\
(3.95)\end{array}$ & $\begin{array}{c}0.087 * * * \\
(4.04)\end{array}$ & $\begin{array}{c}0.570 * * * \\
(3.95)\end{array}$ & $\begin{array}{l}0.033 \\
(1.05)\end{array}$ & $\begin{array}{l}0.042 \\
(1.42)\end{array}$ & $\begin{array}{l}0.037 \\
(1.24)\end{array}$ & $\begin{array}{l}0.024 \\
(1.25)\end{array}$ & $\begin{array}{l}0.042 \\
(1.29)\end{array}$ & $\begin{array}{c}0.076 * * \\
(2.48)\end{array}$ & $\begin{array}{l}0.046 \\
(1.05)\end{array}$ & $\begin{array}{c}0.038^{*} \\
(1.68)\end{array}$ & $\begin{array}{c}0.0079 \\
(0.30)\end{array}$ \\
\hline 50 percent & $\begin{array}{c}0.087 * * * \\
(4.15)\end{array}$ & $\begin{array}{c}0.079 * * * \\
(3.92)\end{array}$ & $\begin{array}{c}0.553 * * * \\
(4.30)\end{array}$ & $\begin{array}{l}0.019 \\
(0.69)\end{array}$ & $\begin{array}{l}0.043 \\
(1.61)\end{array}$ & $\begin{array}{l}0.016 \\
(0.59)\end{array}$ & $\begin{array}{l}0.013 \\
(0.77)\end{array}$ & $\begin{array}{l}0.021 \\
(0.69)\end{array}$ & $\begin{array}{c}0.093 * * * \\
(3.46)\end{array}$ & $\begin{array}{c}0.088 \\
(2.30)^{* *}\end{array}$ & $\begin{array}{l}0.021 \\
(1.03)\end{array}$ & $\begin{array}{l}0.012 \\
(0.05)\end{array}$ \\
\hline 60 percent & $\begin{array}{c}0.094 * * * \\
(4.67)\end{array}$ & $\begin{array}{c}0.083 * * * \\
(4.20)\end{array}$ & $\begin{array}{c}0.731 * * * \\
(6.61)\end{array}$ & $\begin{array}{c}0.055 * * \\
(2.09))\end{array}$ & $\begin{array}{c}0.051 * * \\
(2.02)\end{array}$ & $\begin{array}{l}0.034 \\
(1.31)\end{array}$ & $\begin{array}{l}0.010 \\
(0.58)\end{array}$ & $\begin{array}{l}0.040 \\
(1.41)\end{array}$ & $\begin{array}{l}-0.019 \\
(-0.69)\end{array}$ & $\begin{array}{l}-0.022 \\
(-0.58)\end{array}$ & $\begin{array}{c}0.045^{* *} \\
(2.31)\end{array}$ & $\begin{array}{l}0.013 \\
(0.59)\end{array}$ \\
\hline
\end{tabular}

\section{Table 11: European markets volatility pre and post-announcement}

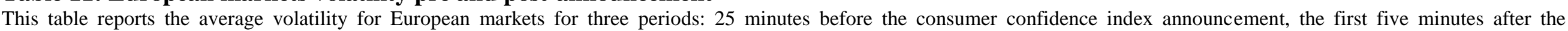

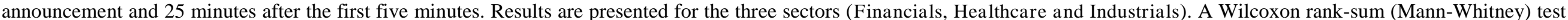

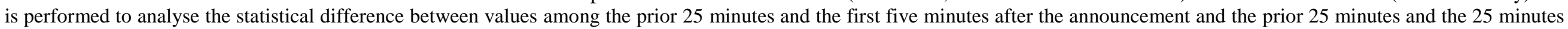
after the first five minutes. Statistical significance of volatility is reported. $* * * * *, *$ and denotes significance at the $1 \%, 5 \%$, and $10 \%$ level, respectively

\begin{tabular}{|c|c|c|c|c|c|c|}
\hline & \multicolumn{3}{|c|}{ Time in minutes } & \multicolumn{3}{|c|}{ Time in minutes } \\
\hline Average Volatility & $\begin{array}{l}\text { Prior } 25 \\
\text { minutes }\end{array}$ & $\begin{array}{c}\text { First } 5 \\
\text { minutes }\end{array}$ & Wilcoxon & $\begin{array}{l}\text { Prior } 25 \\
\text { minutes }\end{array}$ & $\begin{array}{l}\text { Remaining } \\
25 \text { minutes }\end{array}$ & Wilcoxon \\
\hline Financials & $9.79 \% * * *$ & $14.36 \% * * *$ & $-6.801 * * *$ & $9.79 \% * * *$ & $9.58 \% * * *$ & 0.480 \\
\hline Healthcare & $13.16 \%$ *** & $14.54 \% * *$ & $-3.079 * * *$ & $13.16 \%$ *** & $6.49 \% * * *$ & 0.951 \\
\hline Industrials & $7.88 \% * * *$ & $12.29 \% * * *$ & $-6.385 * * *$ & $7.88 \% * * *$ & $6.98 \% * * *$ & 0.885 \\
\hline
\end{tabular}




\section{Table 12: Volatility Spillover effect in European Equity markets (end of day/next day)}

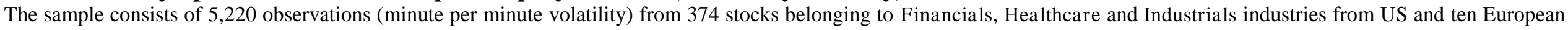
markets (Athens, Brussels, Paris, Frankfurt, London, Madrid, Dublin, Milan, Stockholm and Zurich) for the period January to June 2011. The following regression is estimated:

$$
G K e_{m, i, t+1}=\alpha+\beta_{1} G K e_{-} U S_{i, t}+\varepsilon_{m, i, t}
$$

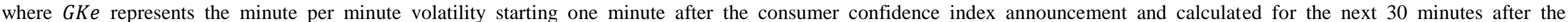

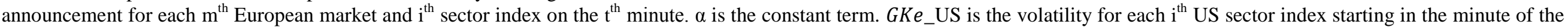

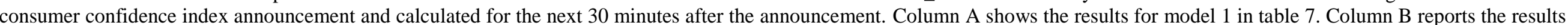

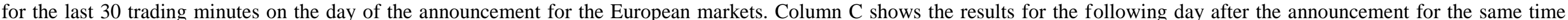

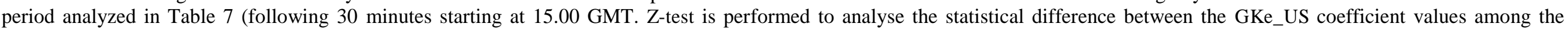
regressions/columns A, B and C. (A-B and A-C). ***,**,* and denotes significance at the $1 \%, 5 \%$, and $10 \%$ (one-tailed) level, respectively.

\begin{tabular}{|c|c|c|c|c|c|}
\hline & \multicolumn{3}{|c|}{ Model 1} & \multicolumn{2}{|c|}{ Z-test } \\
\hline Constant & $\begin{array}{c}0.059 * * * \\
(13.100)\end{array}$ & $\begin{array}{c}0.077 * * * * \\
(29.38)\end{array}$ & $\begin{array}{c}0.067 * * * * \\
(19.78)\end{array}$ & & \\
\hline
\end{tabular}




\section{Table 13: Volatility Spillover effect in European Equity markets (4)}

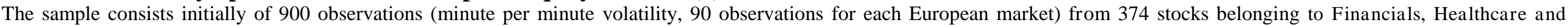

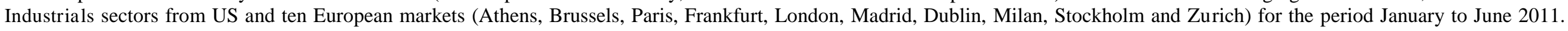
The following regression is estimated:

$$
G K e_{m, i, t+1}=\alpha+\beta_{1} G K e_{-} U S_{i, t}+\beta_{2} G K e_{-} U S_{i, t-1}+\beta_{2} G K e_{-} U S_{i, t-2}+\beta_{2} G K e_{-} U S_{i, t-3}+\beta_{2} G K e_{-} U S_{i, t-4}+\sum_{k=1}^{L} \beta_{2, k}\left(G K e_{-} U S_{i, t} \times D_{m, k, t}\right)+\varepsilon_{m, i, t}
$$

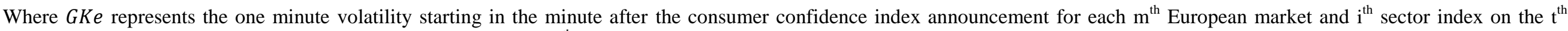

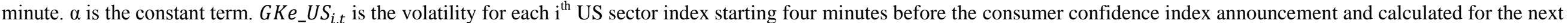

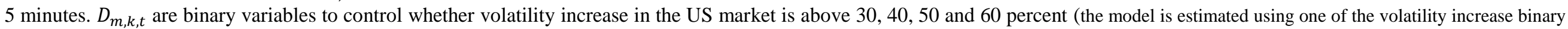
variables at a time). $\varepsilon_{m, i, t}$ is the error term. $* * *, * * *$ and denotes significance at the $1 \%, 5 \%$, and $10 \%$ level, respectively. T-statistics are reported in parenthesis.

\begin{tabular}{|c|c|c|c|c|c|c|c|c|c|c|c|}
\hline Variables & $\begin{array}{c}\text { European } \\
\text { Markets }\end{array}$ & Athens & Brussels & Paris & Frankfurt & London & Madrid & Dublin & Milan & Stockholm & Zurich \\
\hline$G K e_{-} U S_{t}$ & $\begin{array}{c}0.624 * * \\
(2.32)\end{array}$ & $\begin{array}{l}-1.219 \\
(-0.53)\end{array}$ & $\begin{array}{l}0.149 \\
(0.40)\end{array}$ & $\begin{array}{c}1.183 * * * \\
(3.44)\end{array}$ & $\begin{array}{c}1.042 * * * \\
(3.07)\end{array}$ & $\begin{array}{c}0.982 * * * \\
(4.44)\end{array}$ & $\begin{array}{c}1.685 * * * \\
(4.41)\end{array}$ & $\begin{array}{l}-0.378 \\
(-1.04)\end{array}$ & $\begin{array}{c}1.351 * * \\
(2.43)\end{array}$ & $\begin{array}{c}1.020 * * * \\
(4.12)\end{array}$ & $\begin{array}{l}0.421 \\
(1.30)\end{array}$ \\
\hline$G K e_{-} U S_{t-1}$ & $\begin{array}{l}-0.492 \\
(-1.60)\end{array}$ & $\begin{array}{l}-0.570 \\
(-0.21)\end{array}$ & $\begin{array}{l}-0.156 \\
(-0.37)\end{array}$ & $\begin{array}{l}-0.502 \\
(-1.28)\end{array}$ & $\begin{array}{c}-0.822 * * \\
(-2.13)\end{array}$ & $\begin{array}{r}-0.416 \\
(1.64)\end{array}$ & $\begin{array}{c}-0.956^{* *} \\
(-2.20)\end{array}$ & $\begin{array}{l}-0.317 \\
(-0.77)\end{array}$ & $\begin{array}{l}-0.655 \\
(-1.03)\end{array}$ & $\begin{array}{l}-0.433 \\
(-1.54)\end{array}$ & $\begin{array}{l}-0.070 \\
(-0.19)\end{array}$ \\
\hline$G K e_{-} U S_{t-2}$ & $\begin{array}{l}-0.080 \\
(-0.25)\end{array}$ & $\begin{array}{l}-1.588 \\
(-0.58)\end{array}$ & $\begin{array}{l}-.0141 \\
(-0.32)\end{array}$ & $\begin{array}{l}0.170 \\
(0.41)\end{array}$ & $\begin{array}{l}0.372 \\
(0.92)\end{array}$ & $\begin{array}{l}0.176 \\
(0.67)\end{array}$ & $\begin{array}{l}0.549 \\
(1.21)\end{array}$ & $\begin{array}{l}-0.205 \\
(-0.47)\end{array}$ & $\begin{array}{l}0.135 \\
(0.20)\end{array}$ & $\begin{array}{l}-0.088 \\
(-0.30)\end{array}$ & $\begin{array}{l}-0.140 \\
(-0.37)\end{array}$ \\
\hline$G K e_{-} U S_{t-3}$ & $\begin{array}{l}-0.198 \\
(-0.60)\end{array}$ & $\begin{array}{l}0.848 \\
(0.30)\end{array}$ & $\begin{array}{l}-0.067 \\
(-0.15)\end{array}$ & $\begin{array}{c}-0.708 * \\
(-1.67)\end{array}$ & $\begin{array}{l}-0.602 \\
(-1.44)\end{array}$ & $\begin{array}{l}-0.350 \\
(-1.29)\end{array}$ & $\begin{array}{l}-0.727 \\
(-1.55)\end{array}$ & $\begin{array}{l}-0.467 \\
(-1.05)\end{array}$ & $\begin{array}{l}0.308 \\
(0.45)\end{array}$ & $\begin{array}{l}-0.090 \\
(-0.29)\end{array}$ & $\begin{array}{l}-0.126 \\
(-0.32)\end{array}$ \\
\hline$G K e_{-} U S_{t-4}$ & $\begin{array}{c}-0.1140 \\
(-0.28)\end{array}$ & $\begin{array}{l}-5.322 \\
(-1.53)\end{array}$ & $\begin{array}{l}-0.149 \\
(-0.27)\end{array}$ & $\begin{array}{c}1.283 * * * \\
(2.49)\end{array}$ & $\begin{array}{l}0.921^{*} \\
(1.81)\end{array}$ & $\begin{array}{c}0.735^{* *} \\
(2.22)\end{array}$ & $\begin{array}{l}0.791 \\
(1.39)\end{array}$ & $\begin{array}{l}-0.331 \\
(-0.61)\end{array}$ & $\begin{array}{l}-0.095 \\
(-0.11)\end{array}$ & $\begin{array}{l}0.735^{*} \\
(1.98)\end{array}$ & $\begin{array}{l}0.280 \\
(0.58)\end{array}$ \\
\hline$G K e_{-} U S_{t \times} 40$ percent & $\begin{array}{l}0.232 \\
(1.12)\end{array}$ & $\begin{array}{l}1.180 \\
(0.66)\end{array}$ & $\begin{array}{l}0.135 \\
(0.47)\end{array}$ & $\begin{array}{l}0.351 \\
(1.33)\end{array}$ & $\begin{array}{l}-0.143 \\
(-0.54)\end{array}$ & $\begin{array}{l}-0.066 \\
(-0.38)\end{array}$ & $\begin{array}{l}0.203 \\
(0.68)\end{array}$ & $\begin{array}{l}-0.111 \\
(-0.39)\end{array}$ & $\begin{array}{l}0.735^{*} \\
(1.72)\end{array}$ & $\begin{array}{l}0.094 \\
(0.49)\end{array}$ & $\begin{array}{l}-0.046 \\
(-0.18)\end{array}$ \\
\hline Constant & $\begin{array}{c}0.152 * * * \\
(5.85)\end{array}$ & $\begin{array}{c}0.841 * * * \\
(3.75)\end{array}$ & $\begin{array}{c}0.013^{* * * *} \\
(3.65)\end{array}$ & $\begin{array}{l}0.063^{*} \\
(1.91)\end{array}$ & $\begin{array}{c}0.085 * * \\
(2.58)\end{array}$ & $\begin{array}{l}0.015 \\
(0.68)\end{array}$ & $\begin{array}{l}0.040 \\
(1.07)\end{array}$ & $\begin{array}{c}0.173 * * * \\
(4.92)\end{array}$ & $\begin{array}{l}0.073 \\
(1.35)\end{array}$ & $\begin{array}{l}0.023 \\
(0.96)\end{array}$ & $\begin{array}{c}0.075^{* *} \\
(2.41)\end{array}$ \\
\hline $\begin{array}{l}\text { Observations } \\
\text { Adj. R-Squared }\end{array}$ & $\begin{array}{c}900 \\
0.0073 \\
\end{array}$ & $\begin{array}{c}90 \\
0.0204 \\
\end{array}$ & $\begin{array}{c}90 \\
0.001 \\
\end{array}$ & $\begin{array}{c}90 \\
0.1945 \\
\end{array}$ & $\begin{array}{c}90 \\
0.1229 \\
\end{array}$ & $\begin{array}{c}90 \\
0.2508 \\
\end{array}$ & $\begin{array}{c}90 \\
0.2043 \\
\end{array}$ & $\begin{array}{c}90 \\
0.0974\end{array}$ & $\begin{array}{c}90 \\
0.0213 \\
\end{array}$ & $\begin{array}{c}90 \\
0.2342 \\
\end{array}$ & $\begin{array}{c}90 \\
0.001\end{array}$ \\
\hline
\end{tabular}




\section{Appendix A: Volatility Spillover effect in European Equity markets}

The sample consists initially 5,220 observations (minute per minute volatility) from 374 stocks belonging to Financials, Healthcare and Industrials sectors from US and ten European markets (Athens, Brussels, Paris, Frankfurt, London, Madrid, Dublin, Milan, Stockholm and Zurich) for the period January to June 2011. The following regression is estimated:

$$
G K e_{m, i, t+n}=\alpha+\beta_{1} G K e_{-} U S_{i, t}+\sum_{k=1}^{L} \beta_{2, k}\left(G K e_{-} U S_{i, t} \times D_{m, k, t}\right)+\varepsilon_{m, i, t}
$$

Where $G K e$ represents the minute per minute volatility starting from 1 to 5 minutes after the consumer confidence index announcement and calculated for the next 30 minutes after the announcement for each $\mathrm{m}^{\text {th }}$ European market and $\mathrm{i}^{\mathrm{th}}$ sector index on the $\mathrm{t}^{\text {th }}$ minute, with $\mathrm{n}$ assuming the values of 1 to 5 . $\alpha$ is the constant term. GKe US is the volatility for each $\mathrm{i}^{\text {th }}$ US sector index starting in the minute of the consumer confidence index announcement and calculated for the next 30 minutes after the announcement. $D_{m, k, t}$ are binary variables to control for sectors (Healthcare and Industrials) and whether volatility increase in the US market is above 30,50 and 60 percent (the model is estimated using one of the volatility increase binary variables at a time). $\varepsilon_{m, i, t}$ is the error term. ***, **, * and denotes significance at the $1 \%$, $5 \%$, and $10 \%$ level, respectively. T-statistics are reported in parenthesis.

Panel A: 30 percent volatility increase

\begin{tabular}{|c|c|c|c|c|c|}
\hline Variables & $\begin{array}{l}\text { European } \\
\text { markets }_{\mathrm{t}+1}\end{array}$ & $\begin{array}{l}\text { European } \\
\text { markets }_{\mathrm{t}+2}\end{array}$ & $\begin{array}{l}\text { European } \\
\text { markets }_{\mathrm{t}+3}\end{array}$ & $\begin{array}{l}\text { European } \\
\text { markets } \\
\mathrm{t}+4\end{array}$ & $\begin{array}{l}\text { European } \\
\text { markets }_{\mathrm{t}+5}\end{array}$ \\
\hline GKe_US & $\begin{array}{c}1.028 * * * \\
(7.44)\end{array}$ & $\begin{array}{c}0.652 * * * \\
(4.94)\end{array}$ & $\begin{array}{c}0.514 * * * \\
(4.03)\end{array}$ & $\begin{array}{c}0.499 * * * \\
(4.08)\end{array}$ & $\begin{array}{c}0.638 * * * \\
(5.47)\end{array}$ \\
\hline GKe_US $\times$ Healthcare & $\begin{array}{c}-0.607 * * * \\
(-5.80)\end{array}$ & $\begin{array}{c}-0.556 * * * \\
(-5.55)\end{array}$ & $\begin{array}{c}-0.525^{* *} \\
(-5.42)\end{array}$ & $\begin{array}{c}-0.548 * * * \\
(-5.90)\end{array}$ & $\begin{array}{c}-0.558 * * 8 \\
(-6.30)\end{array}$ \\
\hline GKe_US $\times$ Industrials & $\begin{array}{c}-0.649 * * * \\
(-6.35)\end{array}$ & $\begin{array}{c}-0.534 * * * \\
(-5.46)\end{array}$ & $\begin{array}{c}-0.476 * * * \\
(-5.02)\end{array}$ & $\begin{array}{c}-0.468 * * * \\
(-5.15)\end{array}$ & $\begin{array}{c}-0.512 * * * \\
(-5.91)\end{array}$ \\
\hline GKe_US $\times 30$ percent & $\begin{array}{l}0.073 \\
(0.80)\end{array}$ & $\begin{array}{l}0.114 \\
(1.29)\end{array}$ & $\begin{array}{l}0.136 \\
(1.59)\end{array}$ & $\begin{array}{c}0.136^{*} \\
(1.66)\end{array}$ & $\begin{array}{c}0.148^{*} \\
(1.90)\end{array}$ \\
\hline Constant & $\begin{array}{c}0.054 * * * \\
(11.65)\end{array}$ & $\begin{array}{c}0.065 * * * \\
(14.37)\end{array}$ & $\begin{array}{c}0.067 * * * \\
(15.20)\end{array}$ & $\begin{array}{c}0.066 * * * \\
(15.36)\end{array}$ & $\begin{array}{c}0.058 * * * \\
(14.05)\end{array}$ \\
\hline $\begin{array}{l}\text { Observations } \\
\text { Adj. R-Squared }\end{array}$ & $\begin{array}{l}5,220 \\
0.020\end{array}$ & $\begin{array}{c}5,040 \\
0.0133\end{array}$ & $\begin{array}{c}4,860 \\
0.0119\end{array}$ & $\begin{array}{c}4,680 \\
0.0134\end{array}$ & $\begin{array}{c}4,500 \\
0.0200\end{array}$ \\
\hline
\end{tabular}


Panel B: 50 percent volatility increase

\begin{tabular}{|c|c|c|c|c|c|}
\hline Variables & $\begin{array}{l}\text { European } \\
\text { markets }_{\mathrm{t}+1}\end{array}$ & $\begin{array}{l}\text { European } \\
\text { markets }_{\mathrm{t}+2}\end{array}$ & $\begin{array}{l}\text { European } \\
\text { markets }_{\mathrm{t}+3}\end{array}$ & $\begin{array}{l}\text { European } \\
\text { markets }_{\mathrm{t}+4}\end{array}$ & $\begin{array}{l}\text { European } \\
\text { markets }_{\mathrm{t}+5}\end{array}$ \\
\hline$G K e_{-} U S$ & $\begin{array}{c}0.950 * * * \\
(8.06)\end{array}$ & $\begin{array}{c}0.592 * * * \\
(5.25)\end{array}$ & $\begin{array}{c}0.469 * * * \\
(4.30)\end{array}$ & $\begin{array}{c}0.439 * * * \\
(4.19)\end{array}$ & $\begin{array}{c}0.585 * * * \\
(5.87)\end{array}$ \\
\hline GKe_US $\times$ Healthcare & $\begin{array}{c}-0.649 * * * \\
(-6.26)\end{array}$ & $\begin{array}{c}-0.609 * * * \\
(-6.14)\end{array}$ & $\begin{array}{c}-0.583 * * * * \\
(-6.09)\end{array}$ & $\begin{array}{c}-0.609 * * * \\
(-6.63)\end{array}$ & $\begin{array}{c}-0.623 * * * \\
(-7.11)\end{array}$ \\
\hline GKe_US $\times$ Industrials & $\begin{array}{c}-0.658 * * * \\
(-7.16)\end{array}$ & $\begin{array}{c}-0.559 * * * \\
(-6.35)\end{array}$ & $\begin{array}{c}-0.510 * * * \\
(-5.99)\end{array}$ & $\begin{array}{c}-0.499 * * * \\
(-6.12)\end{array}$ & $\begin{array}{c}-0.548 * * * \\
(-7.06\end{array}$ \\
\hline GKe_US $\times 50$ percent & $\begin{array}{c}0.210 * * * \\
(2.74)\end{array}$ & $\begin{array}{c}0.240 * * * \\
(3.26)\end{array}$ & $\begin{array}{c}0.250 * * * \\
(3.52)\end{array}$ & $\begin{array}{c}0.270 * * * \\
(3.96)\end{array}$ & $\begin{array}{c}0.278 * * * \\
(4.28)\end{array}$ \\
\hline Constant & $\begin{array}{c}0.056 * * * \\
(11.92)\end{array}$ & $\begin{array}{c}0.066^{* * *} * \\
(14.69)\end{array}$ & $\begin{array}{c}0.069 * * * \\
(15.56)\end{array}$ & $\begin{array}{c}0.068 * * * \\
(15.78)\end{array}$ & $\begin{array}{c}0.060 * * * \\
(14.52)\end{array}$ \\
\hline Observations & 5,220 & 5,040 & 4,860 & 4,680 & 4,500 \\
\hline Adj. R-Squared & 0.0225 & 0.0151 & 0.0139 & 0.0161 & 0.0232 \\
\hline
\end{tabular}

Panel C: 60 percent volatility increase

\begin{tabular}{|c|c|c|c|c|c|}
\hline Variables & $\begin{array}{l}\text { European } \\
\text { markets }_{\mathrm{t}+1}\end{array}$ & $\begin{array}{l}\text { European } \\
\text { markets }_{\mathrm{t}+2}\end{array}$ & $\begin{array}{l}\text { European } \\
\text { markets }_{\mathrm{t}+3}\end{array}$ & $\begin{array}{l}\text { European } \\
\text { markets }_{\mathrm{t}+4}\end{array}$ & $\begin{array}{l}\text { European } \\
\text { markets }_{\mathrm{t}+5}\end{array}$ \\
\hline$G K e_{-} U S$ & $\begin{array}{c}0.875^{* * * *} \\
(7.35)\end{array}$ & $\begin{array}{c}0.527 * * * \\
(4.62)\end{array}$ & $\begin{array}{c}0.412 * * * \\
(3.74)\end{array}$ & $\begin{array}{c}0.377 * * * \\
(3.56)\end{array}$ & $\begin{array}{l}0.527 * * * \\
(5.22)\end{array}$ \\
\hline GKe_US $\times$ Healthcare & $\begin{array}{c}-0.571 * * * \\
(-5.50)\end{array}$ & $\begin{array}{c}-0.527 * * * \\
(-5.30)\end{array}$ & $\begin{array}{c}-0.499 * * * \\
(-5.20)\end{array}$ & $\begin{array}{c}-0.517 * * * \\
(-5.62)\end{array}$ & $\begin{array}{c}-0.530 * * * \\
(-6.05)\end{array}$ \\
\hline GKe_US $\times$ Industrials & $\begin{array}{c}-0.650 * * * \\
(-7.08)\end{array}$ & $\begin{array}{c}-0.553 * * * \\
(-6.29)\end{array}$ & $\begin{array}{c}-0.505 * * * \\
(-5.94)\end{array}$ & $\begin{array}{c}-0.493 * * * \\
(-6.05)\end{array}$ & $\begin{array}{c}-0.543 * * * \\
(-7.00)\end{array}$ \\
\hline GKe_US $\times 60$ percent & $\begin{array}{c}0.297 * * * \\
(3.93)\end{array}$ & $\begin{array}{c}0.309 * * * \\
(4.27)\end{array}$ & $\begin{array}{c}0.308 * * * \\
(4.40)\end{array}$ & $\begin{array}{c}0.333 * * * \\
(4.96)\end{array}$ & $\begin{array}{c}0.334 * * * \\
(5.22)\end{array}$ \\
\hline Constant & $\begin{array}{c}0.058 * * * \\
(12.21)\end{array}$ & $\begin{array}{c}0.068 * * * \\
(14.97)\end{array}$ & $\begin{array}{c}0.071^{* * * *} \\
(15.83)\end{array}$ & $\begin{array}{c}0.070 * * * \\
(16.11)\end{array}$ & $\begin{array}{c}0.062 * * * \\
(14.88)\end{array}$ \\
\hline $\begin{array}{l}\text { Observations } \\
\text { Adj. R-Squared }\end{array}$ & $\begin{array}{c}5,220 \\
0.0239\end{array}$ & $\begin{array}{c}5,040 \\
0.0166\end{array}$ & $\begin{array}{c}4,860 \\
0.0153\end{array}$ & $\begin{array}{c}4,680 \\
0.0180\end{array}$ & 4,500 \\
\hline
\end{tabular}




\section{Appendix B: Volatility Spillover effect in European Equity markets}

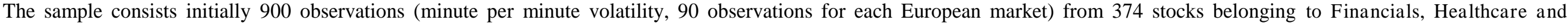

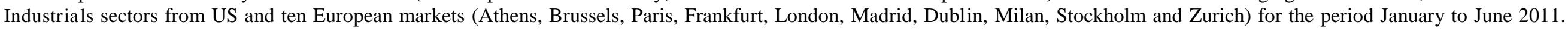
The following regression is estimated:

$$
G K e_{m, i, t+1}=\alpha+\sum_{k=1}^{L} \beta_{1, k}\left(G K e_{-} U S_{i, t} \times D_{m, k, t}\right)+\varepsilon_{m, i, t}
$$

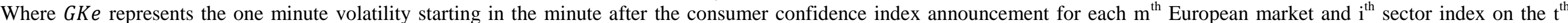

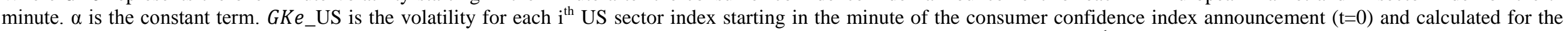

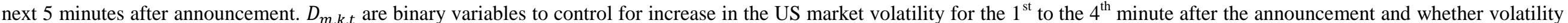

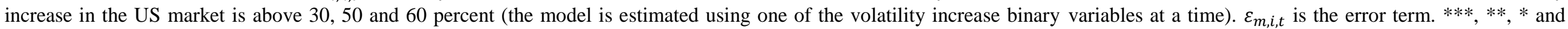
denotes significance at the $1 \%, 5 \%$, and $10 \%$ level, respectively. T-statistics are reported in parenthesis.

\section{Panel A: 30 percent volatility increase}

\begin{tabular}{|c|c|c|c|c|c|c|c|c|c|c|c|}
\hline Variables & $\begin{array}{c}\text { European } \\
\text { Markets }\end{array}$ & Athens & Brussels & Paris & Frankfurt & London & Madrid & Dublin & Milan & Stockholm & Zurich \\
\hline GKe_US $\times 1^{\text {st }}$ minute & $\begin{array}{c}0.764 * * * \\
(2.85)\end{array}$ & $\begin{array}{l}2.681 \\
(1.19)\end{array}$ & $\begin{array}{l}0.443 \\
(1.27)\end{array}$ & $\begin{array}{l}0.350 \\
(1.00)\end{array}$ & $\begin{array}{c}1.089 * * * \\
(3.23)\end{array}$ & $\begin{array}{c}0.617 * * * \\
(2.83)\end{array}$ & $\begin{array}{c}0.988 * * \\
(2.57)\end{array}$ & $\begin{array}{l}0.022 \\
(0.06)\end{array}$ & $\begin{array}{l}0.040 \\
(0.08)\end{array}$ & $\begin{array}{c}0.674 * * \\
(2.62)\end{array}$ & $\begin{array}{c}0.736^{* *} \\
(2.47)\end{array}$ \\
\hline GKe_US $\times 2^{\text {nd }}$ minute & $\begin{array}{c}-0.788^{*} \\
(-1.83)\end{array}$ & $\begin{array}{c}-7.081^{* *} \\
(-1.96)\end{array}$ & $\begin{array}{c}1.651^{* * *} \\
(2.94)\end{array}$ & $\begin{array}{l}-0.458 \\
(-0.82)\end{array}$ & $\begin{array}{l}0.055 \\
(0.10)\end{array}$ & $\begin{array}{l}-0.382 \\
(-1.09)\end{array}$ & $\begin{array}{l}-0.687 \\
(-1.11)\end{array}$ & $\begin{array}{c}0.8424 \\
(1.39)\end{array}$ & $\begin{array}{l}-1.080 \\
(-1.31)\end{array}$ & $\begin{array}{l}-0.138 \\
(-0.33)\end{array}$ & $\begin{array}{c}-0.5997911 \\
(-1.25)\end{array}$ \\
\hline GKe_US $\times 3^{\text {rd }}$ minute & $\begin{array}{l}0.549 \\
(1.52)\end{array}$ & $\begin{array}{c}9.439 * * * \\
(3.12)\end{array}$ & $\begin{array}{l}0.498 \\
(1.06)\end{array}$ & $\begin{array}{c}-1.087 * * \\
(-2.32)\end{array}$ & $\begin{array}{l}-0.361 \\
(-0.80)\end{array}$ & $\begin{array}{c}-0.663 * * \\
(-2.26)\end{array}$ & $\begin{array}{l}-0.295 \\
(-0.57)\end{array}$ & $\begin{array}{l}-0.566 \\
(-1.11)\end{array}$ & $\begin{array}{l}-0.728 \\
(-1.05)\end{array}$ & $\begin{array}{l}-0.360 \\
(-1.04)\end{array}$ & $\begin{array}{l}-0.387 \\
(-0.96)\end{array}$ \\
\hline GKe_US $\times 4^{\text {th }}$ minute & $\begin{array}{c}-0.523 * * \\
(-2.24)\end{array}$ & $\begin{array}{c}-2.517606 \\
(-1.29)\end{array}$ & $\begin{array}{l}0.017 \\
(0.06)\end{array}$ & $\begin{array}{l}-0.441 \\
(-1.45)\end{array}$ & $\begin{array}{c}-0.693^{* * *} \\
(-2.36)\end{array}$ & $\begin{array}{l}-0.301 \\
(-1.58)\end{array}$ & $\begin{array}{c}-0.811^{* *} \\
(-2.42)\end{array}$ & $\begin{array}{l}-0.093 \\
(-0.28)\end{array}$ & $\begin{array}{c}0.668 \\
(1.49)\end{array}$ & $\begin{array}{l}-0.270 \\
(-1.21)\end{array}$ & $\begin{array}{c}-0.789 * * * \\
(-3.04)\end{array}$ \\
\hline GKe_US $\times 30$ percent & $\begin{array}{l}0.257 \\
(1.25)\end{array}$ & $\begin{array}{l}-1.640 \\
(-0.96)\end{array}$ & $\begin{array}{l}-0.304 \\
(-1.14)\end{array}$ & $\begin{array}{c}1.013 * * * \\
(3.80)\end{array}$ & $\begin{array}{c}0.487^{*} \\
(1.89)\end{array}$ & $\begin{array}{c}0.499 * * * \\
(2.99)\end{array}$ & $\begin{array}{c}0.988 * * * * \\
(3.36)\end{array}$ & $\begin{array}{c}-0.551 * \\
(-1.91)\end{array}$ & $\begin{array}{c}1.120 * * * \\
(2.85)\end{array}$ & $\begin{array}{c}0.511^{* *} \\
(2.59)\end{array}$ & $\begin{array}{l}0.444 \\
(1.95)\end{array}$ \\
\hline Constant & $\begin{array}{c}0.092 * * * \\
(4.71)\end{array}$ & $\begin{array}{c}0.278^{*} \\
(1.69)\end{array}$ & $\begin{array}{c}0.0691 * * * \\
(2.72)\end{array}$ & $\begin{array}{c}0.114 * * * \\
(4.46)\end{array}$ & $\begin{array}{c}0.075 * * * \\
(3.03)\end{array}$ & $\begin{array}{c}0.048 * * * \\
(3.01)\end{array}$ & $\begin{array}{c}0.057 * * \\
(2.02)\end{array}$ & $\begin{array}{c}0.084 * * * \\
(3.06)\end{array}$ & $\begin{array}{c}0.088^{* * *} \\
(2.33)\end{array}$ & $\begin{array}{c}0.043 * * \\
(2.31)\end{array}$ & $\begin{array}{c}0.067 * * * \\
(3.09)\end{array}$ \\
\hline $\begin{array}{l}\text { Observations } \\
\text { Adj. R-Squared }\end{array}$ & $\begin{array}{c}900 \\
0.0212\end{array}$ & $\begin{array}{c}90 \\
0.1451\end{array}$ & $\begin{array}{c}90 \\
0.1330\end{array}$ & $\begin{array}{c}90 \\
0.2215\end{array}$ & $\begin{array}{c}90 \\
0.1887\end{array}$ & $\begin{array}{c}90 \\
0.3144\end{array}$ & $\begin{array}{c}90 \\
0.2403\end{array}$ & $\begin{array}{c}90 \\
0.0844\end{array}$ & $\begin{array}{c}90 \\
0.2170\end{array}$ & $\begin{array}{c}90 \\
0.2199\end{array}$ & $\begin{array}{c}90 \\
0.1864\end{array}$ \\
\hline
\end{tabular}


Panel B: 50 percent volatility increase

\begin{tabular}{|c|c|c|c|c|c|c|c|c|c|c|c|}
\hline Variables & $\begin{array}{c}\text { European } \\
\text { Markets }\end{array}$ & Athens & Brussels & Paris & Frankfurt & London & Madrid & Dublin & Milan & Stockholm & Zurich \\
\hline GKe_US $\times 1^{\text {st }}$ minute & $\begin{array}{c}0.822 * * * \\
(3.14)\end{array}$ & $\begin{array}{l}2.234 \\
(1.01)\end{array}$ & $\begin{array}{l}0.359 \\
(1.05)\end{array}$ & $\begin{array}{c}0.596^{*} \\
(1.80)\end{array}$ & $\begin{array}{c}1.213 * * * \\
(3.65)\end{array}$ & $\begin{array}{c}0.742 * * * \\
(3.46)\end{array}$ & $\begin{array}{c}1.233 * * * \\
(3.29)\end{array}$ & $\begin{array}{l}-0.127 \\
(-0.34)\end{array}$ & $\begin{array}{l}0.321 \\
(0.63)\end{array}$ & $\begin{array}{c}0.799 * * * \\
(3.21)\end{array}$ & $\begin{array}{c}0.847 * * 8 \\
(2.90)\end{array}$ \\
\hline GKe_US $\times 2^{\text {nd }}$ minute & $\begin{array}{c}-0.741^{*} \\
(-1.73)\end{array}$ & $\begin{array}{c}-7.366^{* *} \\
(-2.04)\end{array}$ & $\begin{array}{c}1.599 * * * \\
(2.84)\end{array}$ & $\begin{array}{l}-0.275 \\
(-0.51)\end{array}$ & $\begin{array}{l}0.142 \\
(0.26)\end{array}$ & $\begin{array}{l}-0.293 \\
(-0.84)\end{array}$ & $\begin{array}{l}-0.510 \\
(-0.83)\end{array}$ & $\begin{array}{c}0.746 \\
(1.21)\end{array}$ & $\begin{array}{l}-0.881 \\
(-1.06)\end{array}$ & $\begin{array}{l}-0.046 \\
(-0.11)\end{array}$ & $\begin{array}{l}-0.520 \\
(-1.09)\end{array}$ \\
\hline GKe_US $\times 3^{\text {rd }}$ minute & $\begin{array}{l}0.465 \\
(1.29)\end{array}$ & $\begin{array}{c}8.869^{* * *} \\
(2.92)\end{array}$ & $\begin{array}{c}0.376 \\
(0.80)\end{array}$ & $\begin{array}{c}-1.163 * * \\
(-2.55)\end{array}$ & $\begin{array}{l}-0.303 \\
(-0.66)\end{array}$ & $\begin{array}{c}-0.654 * * \\
(-2.22)\end{array}$ & $\begin{array}{l}-0.300 \\
(-0.58)\end{array}$ & $\begin{array}{l}-0.740 \\
(-1.43)\end{array}$ & $\begin{array}{l}-0.672 \\
(-0.96)\end{array}$ & $\begin{array}{l}-0.391 \\
(-1.14)\end{array}$ & $\begin{array}{l}-0.368 \\
(-0.92)\end{array}$ \\
\hline GKe_US $\times 4^{\text {th }}$ minute & $\begin{array}{c}-0.643^{* * *} \\
(-2.65)\end{array}$ & $\begin{array}{l}-2.501 \\
(-1.22)\end{array}$ & $\begin{array}{c}0.009 \\
(0.03)\end{array}$ & $\begin{array}{c}-0.741 * * \\
(-2.42)\end{array}$ & $\begin{array}{c}-0.773 * * \\
(-2.51)\end{array}$ & $\begin{array}{c}-0.417 * * \\
(-2.11)\end{array}$ & $\begin{array}{c}-1.056^{* * *} \\
(-3.04)\end{array}$ & $\begin{array}{c}-0.0760 \\
(-0.22)\end{array}$ & $\begin{array}{l}0.432 \\
(0.92)\end{array}$ & $\begin{array}{c}-0.417^{*} \\
(-1.81)\end{array}$ & $\begin{array}{c}-0.885 * * * \\
(-3.27)\end{array}$ \\
\hline GKe_US $\times 50$ percent & $\begin{array}{c}0.400 * * \\
(2.09)\end{array}$ & $\begin{array}{l}-0.457 \\
(-0.28)\end{array}$ & $\begin{array}{l}-0.052 \\
(-0.21)\end{array}$ & $\begin{array}{l}1.095 \\
(4.52)\end{array}$ & $\begin{array}{l}0.347 \\
(1.43)\end{array}$ & $\begin{array}{c}0.452 * * * \\
(2.89)\end{array}$ & $\begin{array}{c}0.936 * * * \\
(3.41)\end{array}$ & $\begin{array}{l}-0.187 \\
(-0.68)\end{array}$ & $\begin{array}{c}0.944 * * \\
(2.54)\end{array}$ & $\begin{array}{c}0.539 * * * \\
(2.96)\end{array}$ & $\begin{array}{c}0.382^{*} \\
(1.78)\end{array}$ \\
\hline Constant & $\begin{array}{c}0.090 * * * \\
(4.70)\end{array}$ & $\begin{array}{l}0.245 \\
(1.51)\end{array}$ & $\begin{array}{c}0.062 * * \\
(2.47)\end{array}$ & $\begin{array}{c}0.117 * * * \\
(4.79)\end{array}$ & $\begin{array}{c}0.080 * * * \\
(3.26)\end{array}$ & $\begin{array}{c}0.051 * * * \\
(3.26)\end{array}$ & $\begin{array}{c}0.0623 * * \\
(2.26)\end{array}$ & $\begin{array}{c}0.0740 * * * \\
(2.68)\end{array}$ & $\begin{array}{c}0.096 * * * \\
(2.59)\end{array}$ & $\begin{array}{c}0.045^{* *} \\
(2.47)\end{array}$ & $\begin{array}{c}0.071 * * * \\
(3.28)\end{array}$ \\
\hline $\begin{array}{l}\text { Observations } \\
\text { Adj. R-Squared }\end{array}$ & $\begin{array}{c}900 \\
0.0242\end{array}$ & $\begin{array}{c}90 \\
0.1367\end{array}$ & $\begin{array}{c}90 \\
0.1200 \\
\end{array}$ & $\begin{array}{c}90 \\
0.2662 \\
\end{array}$ & $\begin{array}{c}90 \\
0.1742 \\
\end{array}$ & $\begin{array}{c}90 \\
0.3099 \\
\end{array}$ & $\begin{array}{c}90 \\
0.2430 \\
\end{array}$ & $\begin{array}{c}90 \\
0.0499 \\
\end{array}$ & $\begin{array}{c}90 \\
0.2026 \\
\end{array}$ & $\begin{array}{c}90 \\
0.2369 \\
\end{array}$ & $\begin{array}{c}90 \\
0.1805 \\
\end{array}$ \\
\hline \multicolumn{12}{|c|}{ Panel C: 60 percent volatility increase } \\
\hline Variables & $\begin{array}{c}\text { European } \\
\text { Markets }\end{array}$ & Athens & Brussels & Paris & Frankfurt & London & Madrid & Dublin & Milan & Stockholm & Zurich \\
\hline GKe_US $\times 1^{\text {st }}$ minute & $\begin{array}{c}0.719 * * * \\
(2.71)\end{array}$ & $\begin{array}{l}1.9501 \\
(0.87)\end{array}$ & $\begin{array}{l}0.3201 \\
(0.92)\end{array}$ & $\begin{array}{l}0.382 \\
(1.13)\end{array}$ & $\begin{array}{l}1.122 * * * \\
(3.35)\end{array}$ & $\begin{array}{l}0.673 * * * \\
(3.05)\end{array}$ & $\begin{array}{c}1.036^{* * * *} \\
(2.74)\end{array}$ & $\begin{array}{l}-0.039 \\
(-0.10)\end{array}$ & $\begin{array}{l}0.310 \\
(0.58)\end{array}$ & $\begin{array}{c}0.664 * * * \\
(2.70)\end{array}$ & $\begin{array}{c}0.768 * * \\
(2.59)\end{array}$ \\
\hline GKe_US $\times 2^{\text {nd }}$ minute & $\begin{array}{c}-0.876^{* *} \\
(-2.03)\end{array}$ & $\begin{array}{c}-7.660^{* *} \\
(-2.11)\end{array}$ & $\begin{array}{c}1.558 * * * \\
(2.75)\end{array}$ & $\begin{array}{l}-0.569 \\
(-1.04)\end{array}$ & $\begin{array}{c}0.0213 \\
(0.04)\end{array}$ & $\begin{array}{l}-0.392 \\
(-1.09)\end{array}$ & $\begin{array}{l}-0.777 \\
(-1.26)\end{array}$ & $\begin{array}{l}0.855 \\
(1.39)\end{array}$ & $\begin{array}{l}-0.941 \\
(-1.08)\end{array}$ & $\begin{array}{c}-0.2234 \\
(-0.56)\end{array}$ & $\begin{array}{l}-0.628 \\
(-1.30)\end{array}$ \\
\hline GKe_US $\times 3^{\text {rd }}$ minute & $\begin{array}{l}0.504 \\
(1.44)\end{array}$ & $\begin{array}{c}8.239 * * * \\
(2.78)\end{array}$ & $\begin{array}{l}0.294 \\
(0.64)\end{array}$ & $\begin{array}{c}-0.956^{* *} \\
(-2.14)\end{array}$ & $\begin{array}{l}-0.273 \\
(-0.62)\end{array}$ & $\begin{array}{l}-0.540^{*} \\
(-1.84)\end{array}$ & $\begin{array}{l}-0.145 \\
(-0.29)\end{array}$ & $\begin{array}{l}-0.700 \\
(-1.40)\end{array}$ & $\begin{array}{l}-0.242 \\
(-0.34)\end{array}$ & $\begin{array}{l}-0.332 \\
(-1.02)\end{array}$ & $\begin{array}{l}-0.303 \\
(-0.77)\end{array}$ \\
\hline GKe_US $\times 4^{\text {th }}$ minute & $\begin{array}{c}-0.618 * * * \\
(-2.62)\end{array}$ & $\begin{array}{l}-2.930 \\
(-1.47)\end{array}$ & $\begin{array}{c}-0.0470 \\
(-0.15)\end{array}$ & $\begin{array}{c}-0.606 * * \\
(-2.02)\end{array}$ & $\begin{array}{c}-0.754 * * \\
(-2.53)\end{array}$ & $\begin{array}{c}-0.342 * \\
(-1.73)\end{array}$ & $\begin{array}{c}-0.955^{* * *} * \\
(-2.83)\end{array}$ & $\begin{array}{l}-0.047 \\
(-0.14)\end{array}$ & $\begin{array}{l}0.721 \\
(1.52)\end{array}$ & $\begin{array}{c}-0.380^{*} \\
(-1.73)\end{array}$ & $\begin{array}{c}-0.843 * * * \\
(-3.19)\end{array}$ \\
\hline GKe_US $\times 60$ percent & $\begin{array}{c}0.487 * * * \\
(2.61)\end{array}$ & $\begin{array}{l}1.098 \\
(0.70)\end{array}$ & $\begin{array}{l}0.152 \\
(0.62)\end{array}$ & $\begin{array}{c}1.051^{* * * *} \\
(4.44)\end{array}$ & $\begin{array}{c}0.433^{*} \\
(1.84)\end{array}$ & $\begin{array}{c}0.352 * * \\
(2.27)\end{array}$ & $\begin{array}{c}0.957 * * * \\
(3.61)\end{array}$ & $\begin{array}{l}-0.394 \\
(-1.49)\end{array}$ & $\begin{array}{l}0.194 \\
(0.52)\end{array}$ & $\begin{array}{c}0.639 * * * \\
(3.69)\end{array}$ & $\begin{array}{l}0.386^{*} \\
(1.85)\end{array}$ \\
\hline Constant & $\begin{array}{c}0.098 * * * \\
(5.20)\end{array}$ & $\begin{array}{l}0.233 \\
(1.47)\end{array}$ & $\begin{array}{c}0.061 * * \\
(2.47)\end{array}$ & $\begin{array}{c}0.137 * * * \\
(5.74)\end{array}$ & $\begin{array}{c}0.086 * * * \\
(3.63)\end{array}$ & $\begin{array}{c}0.060 * * * \\
(3.83)\end{array}$ & $\begin{array}{l}0.0800^{* * *} \\
(2.98)\end{array}$ & $\begin{array}{c}0.071 * * * \\
(2.65)\end{array}$ & $\begin{array}{c}0.116 * * * \\
(3.07)\end{array}$ & $\begin{array}{c}0.055^{* * * *} \\
(3.16)\end{array}$ & $\begin{array}{c}0.078 * * * \\
(3.70)\end{array}$ \\
\hline $\begin{array}{l}\text { Observations } \\
\text { Adj. R-Squared }\end{array}$ & $\begin{array}{c}900 \\
0.0269\end{array}$ & $\begin{array}{c}90 \\
0.1409\end{array}$ & $\begin{array}{c}90 \\
0.1236\end{array}$ & $\begin{array}{c}90 \\
0.2610\end{array}$ & $\begin{array}{c}90 \\
0.1871\end{array}$ & $\begin{array}{c}90 \\
0.2852\end{array}$ & $\begin{array}{c}90 \\
0.2537\end{array}$ & $\begin{array}{c}90 \\
0.0692\end{array}$ & $\begin{array}{c}90 \\
0.1440\end{array}$ & $\begin{array}{c}90 \\
0.2750\end{array}$ & $\begin{array}{c}90 \\
0.1830\end{array}$ \\
\hline
\end{tabular}




\section{Appendix C: Volatility Spillover effect in European Equity markets}

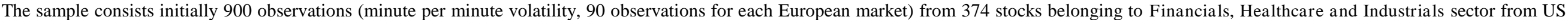
and ten European markets (Athens, Brussels, Paris, Frankfurt, London, Madrid, Dublin, Milan, Stockholm and Zurich) for the period January to June 2011. The following regression is estimated:

$$
G K e_{m, i, t+1}=\alpha+\beta_{1} G K e_{-} U S_{i, t}+\sum_{k=1}^{L} \beta_{2, k} D_{m, k, t}+\varepsilon_{m, i, t}
$$

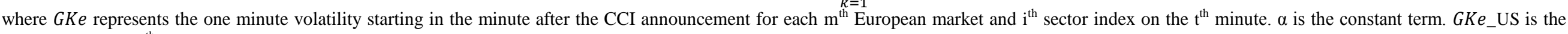

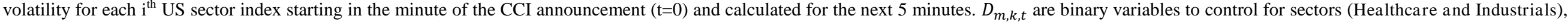

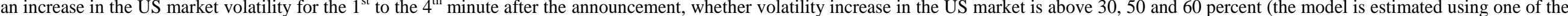

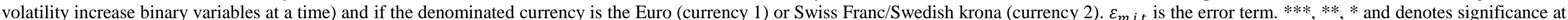
the $1 \%, 5 \%$, and $10 \%$ level, respectively. T-statistics are reported in parenthesis.

\section{Panel A: 30 percent volatility increase}

\begin{tabular}{|c|c|c|c|c|c|c|c|c|c|c|c|c|}
\hline Variables & $\begin{array}{r}\text { Europea } \\
\text { Markets }\end{array}$ & $\begin{array}{c}\text { European } \\
\text { Markets }\end{array}$ & Athens & Brussels & Paris & Frankfurt & London & Madrid & Dublin & Milan & Stockholn & Zurich \\
\hline$G K e_{-} U S$ & $\begin{array}{c}0.741 * * * \\
(3.03)\end{array}$ & $\begin{array}{c}0.613 * * * \\
(2.62)\end{array}$ & $\begin{array}{l}1.109 \\
(0.70)\end{array}$ & $\begin{array}{l}0.277 \\
(0.85)\end{array}$ & $\begin{array}{c}1.210 * * * \\
(3.90)\end{array}$ & $\begin{array}{c}0.809^{* *} \\
(2.57)\end{array}$ & $\begin{array}{c}0.750 * * * \\
(3.87)\end{array}$ & $\begin{array}{c}1.357 * * * \\
(3.94)\end{array}$ & $\begin{array}{l}-0.285 \\
(-0.86)\end{array}$ & $\begin{array}{c}0.890^{*} \\
(1.96)\end{array}$ & $\begin{array}{c}0.833 * * * \\
(3.49)\end{array}$ & $\begin{array}{l}0.459^{*} \\
(1.66)\end{array}$ \\
\hline $1^{\text {st }}$ minute & $\begin{array}{c}0.186 * * * \\
(5.24)\end{array}$ & $\begin{array}{c}0.129 * * * \\
(4.43)\end{array}$ & $\begin{array}{c}1.62 * * * \\
(7.09)\end{array}$ & $\begin{array}{l}0.094 \\
(1.97)\end{array}$ & $\begin{array}{l}-0.029 \\
(-0.64)\end{array}$ & $\begin{array}{l}0.061 \\
(1.34)\end{array}$ & $\begin{array}{l}0.030 \\
(1.05)\end{array}$ & $\begin{array}{l}0.005 \\
(0.09)\end{array}$ & $\begin{array}{l}0.037 \\
(0.75)\end{array}$ & $\begin{array}{l}-0.008 \\
(-0.12)\end{array}$ & $\begin{array}{l}0.025 \\
(0.71)\end{array}$ & $\begin{array}{l}0.027 \\
(0.66)\end{array}$ \\
\hline $2^{\text {nd }}$ minute & $\begin{array}{c}-0.0364 \\
(-1.46)\end{array}$ & $\begin{array}{c}-0.045^{*} \\
(-1.86)\end{array}$ & $\begin{array}{l}-0.162 \\
(-1.01)\end{array}$ & $\begin{array}{c}0.074 * * \\
(2.24)\end{array}$ & $\begin{array}{c}-0.0391 \\
(-1.24)\end{array}$ & $\begin{array}{l}-0.030 \\
(-0.95)\end{array}$ & $\begin{array}{c}-0.053 * * * \\
(-2.71)\end{array}$ & $\begin{array}{c}-0.067 * \\
(-1.92)\end{array}$ & $\begin{array}{c}0.093 * * * \\
(2.74)\end{array}$ & $\begin{array}{c}-0.094 * * \\
(-2.04)\end{array}$ & $\begin{array}{l}-0.036 \\
(-1.46)\end{array}$ & $\begin{array}{c}-0.049 * \\
(-1.73)\end{array}$ \\
\hline $3^{\text {rd }}$ minute & $\begin{array}{c}0.0506^{*} \\
(1.80)\end{array}$ & $\begin{array}{c}0.068 * * \\
(2.51)\end{array}$ & $\begin{array}{c}0.856^{* * *} \\
(4.74)\end{array}$ & $\begin{array}{l}0.042 \\
(1.11)\end{array}$ & $\begin{array}{c}-0.090^{* *} \\
(-2.54)\end{array}$ & $\begin{array}{l}-0.029 \\
(-0.81)\end{array}$ & $\begin{array}{c}-0.080 * * * \\
(-3.61)\end{array}$ & $\begin{array}{c}-0.067 * \\
(-1.69)\end{array}$ & $\begin{array}{l}-0.023 \\
(-0.60)\end{array}$ & $\begin{array}{l}-0.044 \\
(-0.84)\end{array}$ & $\begin{array}{l}-0.030 \\
(-1.11)\end{array}$ & $\begin{array}{l}-0.027 \\
(-0.86)\end{array}$ \\
\hline $4^{\text {th }}$ minute & $\begin{array}{c}-0.098^{* * *} \\
(-3.49)\end{array}$ & $\begin{array}{l}-0.055 \\
(-2.58)\end{array}$ & $\begin{array}{c}-0.711^{* * *} \\
(-3.94)\end{array}$ & $\begin{array}{l}-0.039 \\
(-1.05)\end{array}$ & $\begin{array}{l}-0.046 \\
(-1.29)\end{array}$ & $\begin{array}{c}-0.060^{*} \\
(-1.65)\end{array}$ & $\begin{array}{c}-0.049 * * \\
(-2.21)\end{array}$ & $\begin{array}{c}-0.082 * * \\
(-2.09)\end{array}$ & $\begin{array}{l}-0.037 \\
(-0.96)\end{array}$ & $\begin{array}{c}0.129 * * \\
(2.48)\end{array}$ & $\begin{array}{l}-0.037 \\
(-1.35)\end{array}$ & $\begin{array}{l}-0.044 \\
(-1.40)\end{array}$ \\
\hline 30 percent & $\begin{array}{c}0.094 * * * \\
(2.94)\end{array}$ & $\begin{array}{c}0.048 * * \\
(2.01)\end{array}$ & $\begin{array}{c}0.603 * * * \\
(2.94)\end{array}$ & $\begin{array}{l}0.023 \\
(0.55)\end{array}$ & $\begin{array}{l}0.042 \\
(1.03)\end{array}$ & $\begin{array}{l}0.055 \\
(1.35)\end{array}$ & $\begin{array}{c}0.057 * * \\
(2.25)\end{array}$ & $\begin{array}{l}0.056 \\
(1.24)\end{array}$ & $\begin{array}{l}-0.034 \\
(-0.79)\end{array}$ & $\begin{array}{l}0.078 \\
(1.32)\end{array}$ & $\begin{array}{l}0.044 \\
(1.43)\end{array}$ & $\begin{array}{l}0.012 \\
(0.33)\end{array}$ \\
\hline Healthcare & $\begin{array}{c}0.084 \\
(2.85)^{* * *}\end{array}$ & --- & $\begin{array}{c}0.954 * * * \\
(5.04)\end{array}$ & $\begin{array}{l}0.048 \\
(1.22)\end{array}$ & $\begin{array}{l}-0.007 \\
(-0.20)\end{array}$ & $\begin{array}{l}-0.034 \\
(-0.90)\end{array}$ & $\begin{array}{l}0.023 \\
(0.97)\end{array}$ & $\begin{array}{l}-0.027 \\
(-0.66)\end{array}$ & $\begin{array}{l}-0.031 \\
(-0.76)\end{array}$ & $\begin{array}{l}-0.032 \\
(-0.59)\end{array}$ & $\begin{array}{l}-0.005 \\
(-0.18)\end{array}$ & $\begin{array}{c}-0.05 \\
(-1.51)\end{array}$ \\
\hline Industrials & $\begin{array}{c}0.078^{* *} \\
(2.18)\end{array}$ & --- & $\begin{array}{c}0.884 * * * \\
(3.84)\end{array}$ & $\begin{array}{c}0.103 * * \\
(2.16)\end{array}$ & $\begin{array}{l}-0.049 \\
(-1.09)\end{array}$ & $\begin{array}{l}0.008 \\
(0.17)\end{array}$ & $\begin{array}{l}0.036 \\
(1.28)\end{array}$ & $\begin{array}{l}-0.022 \\
(-0.44)\end{array}$ & $\begin{array}{l}-0.015 \\
(-0.30)\end{array}$ & $\begin{array}{c}-0.132 * * \\
(-1.99)\end{array}$ & $\begin{array}{l}0.024 \\
(0.68)\end{array}$ & $\begin{array}{l}-0.057 \\
(-1.41)\end{array}$ \\
\hline Currency 1 & --- & $\begin{array}{c}0.062 * * \\
(2.05)\end{array}$ & --- & --- & --- & --- & --- & --- & --- & --- & --- & --- \\
\hline Currency 2 & --- & $\begin{array}{c}0.008 * * \\
(0.23)\end{array}$ & --- & --- & --- & --- & --- & --- & --- & --- & --- & --- \\
\hline Constant & $\begin{array}{c}-0.168 * * * \\
(-2.64)\end{array}$ & $\begin{array}{l}-0.085 \\
(-1.63)\end{array}$ & $\begin{array}{c}-2.071 * * * \\
(-5.03)\end{array}$ & $\begin{array}{l}-0.072 \\
(-0.84)\end{array}$ & $\begin{array}{l}0.119 \\
(1.47)\end{array}$ & $\begin{array}{l}0.031 \\
(0.38)\end{array}$ & $\begin{array}{l}-0.007 \\
(-0.14)\end{array}$ & $\begin{array}{l}0.060 \\
(0.67)\end{array}$ & $\begin{array}{l}0.085 \\
(0.98)\end{array}$ & $\begin{array}{l}0.066 \\
(0.56)\end{array}$ & $\begin{array}{l}0.002 \\
(0.03)\end{array}$ & $\begin{array}{l}0.102 \\
(1.42)\end{array}$ \\
\hline Observations & 900 & 900 & 90 & 90 & 90 & 90 & 90 & 90 & 90 & 90 & 90 & 90 \\
\hline Adj. R-Squared & 0.0476 & 0.0479 & 0.5242 & 0.1428 & 0.3029 & 0.1958 & 0.3868 & 0.3093 & 0.1914 & 0.3072 & 0.2403 & 0.2071 \\
\hline
\end{tabular}


Panel B: 50 percent volatility increase

\begin{tabular}{|c|c|c|c|c|c|c|c|c|c|c|c|c|}
\hline Variables & $\begin{array}{r}\text { Europea } \\
\text { Markets }\end{array}$ & $\begin{array}{r}\text { Europea } \\
\text { Markets }\end{array}$ & Athens & Brussels & Paris & Frankfurt & London & Madrid & Dublin & Milan & Stockholn & Zurich \\
\hline$G K e_{-} U S$ & $\begin{array}{c}0.725 * * * \\
(3.00)\end{array}$ & $\begin{array}{c}0.619 * * * \\
(2.70)\end{array}$ & $\begin{array}{l}1.001 \\
(0.67)\end{array}$ & $\begin{array}{l}0.271 \\
(0.84)\end{array}$ & $\begin{array}{c}1.207 * * * \\
(3.95)\end{array}$ & $\begin{array}{c}0.769^{* *} \\
(2.43)\end{array}$ & $\begin{array}{c}0.706 * * * \\
(3.57)\end{array}$ & $\begin{array}{c}1.320 * * * \\
(3.83)\end{array}$ & $\begin{array}{l}-0.171 \\
(-0.55)\end{array}$ & $\begin{array}{c}0.891 * * \\
(2.01)\end{array}$ & $\begin{array}{c}0.809 * * * \\
(3.39)\end{array}$ & $\begin{array}{c}0.449^{*} \\
(1.65)\end{array}$ \\
\hline $1^{\text {st }}$ minute & $\begin{array}{c}0.209 * * * \\
(5.82)\end{array}$ & $\begin{array}{c}0.170 * * * \\
(5.44)\end{array}$ & $\begin{array}{c}1.763 * * * \\
(7.99)\end{array}$ & $\begin{array}{c}0.0974 * 8 \\
(2.03)\end{array}$ & $\begin{array}{l}-0.016 \\
(-0.35)\end{array}$ & $\begin{array}{l}0.0481 \\
(1.02)\end{array}$ & $\begin{array}{c}0.0134 \\
(0.46)\end{array}$ & $\begin{array}{l}-0.005 \\
(-0.11)\end{array}$ & $\begin{array}{c}0.122 * * * \\
(2.65)\end{array}$ & $\begin{array}{l}0.022 \\
(0.34)\end{array}$ & $\begin{array}{c}0.0204 \\
(0.57)\end{array}$ & $\begin{array}{l}0.022 \\
(0.54)\end{array}$ \\
\hline $2^{\text {nd }}$ minute & $\begin{array}{l}-0.008 \\
(-0.32)\end{array}$ & $\begin{array}{l}-0.023 \\
(-0.99)\end{array}$ & $\begin{array}{l}0.021 \\
(0.14)\end{array}$ & $\begin{array}{c}0.081 * * \\
(2.46)\end{array}$ & $\begin{array}{l}-.0257 \\
(-0.83)\end{array}$ & $\begin{array}{l}-0.020 \\
(-0.61)\end{array}$ & $\begin{array}{c}-0.043 * * \\
(-2.14)\end{array}$ & $\begin{array}{l}-0.056 \\
(-1.58)\end{array}$ & $\begin{array}{c}0.104 * * * \\
(3.31)\end{array}$ & $\begin{array}{l}-0.068 \\
(-1.50)\end{array}$ & $\begin{array}{l}-0.026 \\
(-1.05)\end{array}$ & $\begin{array}{c}-0.047 * \\
(-1.67)\end{array}$ \\
\hline $3^{\text {rd }}$ minute & $\begin{array}{c}0.067 * * \\
(2.54)\end{array}$ & $\begin{array}{c}0.071 * * * \\
(2.71)\end{array}$ & $\begin{array}{c}0.964 * * * \\
(5.91)\end{array}$ & $\begin{array}{l}0.046 \\
(1.30)\end{array}$ & $\begin{array}{c}-0.0835^{* *} * \\
(-2.49)\end{array}$ & $\begin{array}{l}-0.016 \\
(-0.45)\end{array}$ & $\begin{array}{c}-0.066 * * * \\
(-3.02)\end{array}$ & $\begin{array}{l}-0.053 \\
(-1.41)\end{array}$ & $\begin{array}{l}-0.043 \\
(-1.27)\end{array}$ & $\begin{array}{c}-0.0316 \\
(-0.65)\end{array}$ & $\begin{array}{l}-0.020 \\
(-0.77)\end{array}$ & $\begin{array}{l}-0.024 \\
(-0.80)\end{array}$ \\
\hline $4^{\text {th }}$ minute & $\begin{array}{c}-0.091 * * * \\
(-3.54)\end{array}$ & $\begin{array}{c}-0.069 * * * \\
(-3.20)\end{array}$ & $\begin{array}{c}-0.668 * * * \\
(-4.21)\end{array}$ & $\begin{array}{l}-0.037 \\
(-1.07)\end{array}$ & $\begin{array}{l}-0.045 \\
(-1.37)\end{array}$ & $\begin{array}{l}-0.043 \\
(-1.27)\end{array}$ & $\begin{array}{l}-0.030 \\
(-1.43)\end{array}$ & $\begin{array}{c}-0.067 * \\
(-1.82)\end{array}$ & $\begin{array}{c}-0.086 * * \\
(-2.60)\end{array}$ & $\begin{array}{c}0.128 * * * \\
(2.72)\end{array}$ & $\begin{array}{l}-0.026 \\
(-1.04)\end{array}$ & $\begin{array}{l}-0.040 \\
(-1.36)\end{array}$ \\
\hline 50 percent & $\begin{array}{c}0.087 * * * \\
(4.15)\end{array}$ & $\begin{array}{c}0.079 * * * \\
(3.92)\end{array}$ & $\begin{array}{c}0.553 * * * \\
(4.30)\end{array}$ & $\begin{array}{l}0.019 \\
(0.69)\end{array}$ & $\begin{array}{l}0.043 \\
(1.61)\end{array}$ & $\begin{array}{l}0.016 \\
(0.59)\end{array}$ & $\begin{array}{l}0.013 \\
(0.77)\end{array}$ & $\begin{array}{l}0.021 \\
(0.69)\end{array}$ & $\begin{array}{c}0.093 * * * \\
(3.46)\end{array}$ & $\begin{array}{c}0.088 \\
(2.30)^{* *}\end{array}$ & $\begin{array}{l}0.021 \\
(1.03)\end{array}$ & $\begin{array}{l}0.012 \\
(0.05)\end{array}$ \\
\hline Healthcare & $\begin{array}{c}0.062 * * \\
(2.34)\end{array}$ & --- & $\begin{array}{c}0.813 * * * \\
(5.00)\end{array}$ & $\begin{array}{c}0.0419 \\
(1.18)\end{array}$ & $\begin{array}{c}-0.0164 \\
(-0.49)\end{array}$ & $\begin{array}{l}-0.054 \\
(-1.56)\end{array}$ & $\begin{array}{l}0.002 \\
(0.07)\end{array}$ & $\begin{array}{l}-0.046 \\
(-1.23)\end{array}$ & $\begin{array}{l}0.002 \\
(0.06)\end{array}$ & $\begin{array}{l}-0.047 \\
(-0.98)\end{array}$ & $\begin{array}{l}-0.019 \\
(-0.74)\end{array}$ & $\begin{array}{c}-0.055^{*} \\
(-1.83)\end{array}$ \\
\hline Industrials & $\begin{array}{l}0.037 \\
(1.33)\end{array}$ & --- & $\begin{array}{c}0.618 \text { *** } \\
(3.61)\end{array}$ & $\begin{array}{c}0.092^{* *} \\
(2.47)\end{array}$ & $\begin{array}{l}-0.066^{*} \\
(-1.89)\end{array}$ & $\begin{array}{l}-0.028 \\
(-0.76)\end{array}$ & $\begin{array}{l}-0.001 \\
(-0.05)\end{array}$ & $\begin{array}{l}-0.056 \\
(-1.42)\end{array}$ & $\begin{array}{l}0.040 \\
(1.11)\end{array}$ & $\begin{array}{c}-0.162 * * * \\
(-3.17)\end{array}$ & $\begin{array}{l}-0.002 \\
(-0.06)\end{array}$ & $\begin{array}{c}-0.065^{* *} \\
(-2.06)\end{array}$ \\
\hline Currency 1 & --- & $\begin{array}{c}0.062 * * \\
(2.06)\end{array}$ & --- & --- & --- & --- & --- & --- & --- & --- & --- & --- \\
\hline Currency 2 & --- & $\begin{array}{l}0.008 \\
(0.24)\end{array}$ & --- & --- & --- & --- & --- & --- & --- & --- & --- & --- \\
\hline Constant & $\begin{array}{c}-0.153 * * * \\
(-2.83)\end{array}$ & $\begin{array}{c}-0.126^{* *} \\
(-2.45)\end{array}$ & $\begin{array}{c}-1.963 * * * \\
(-5.92)\end{array}$ & $\begin{array}{l}-0.065 \\
(-0.90)\end{array}$ & $\begin{array}{c}0.121^{*} \\
(1.77)\end{array}$ & $\begin{array}{l}0.086 \\
(1.22)\end{array}$ & $\begin{array}{l}0.054 \\
(1.21)\end{array}$ & $\begin{array}{l}0.110 \\
(1.43)\end{array}$ & $\begin{array}{l}-0.082 \\
(-1.18)\end{array}$ & $\begin{array}{l}0.059 \\
(0.59)\end{array}$ & $\begin{array}{l}0.035 \\
(0.66)\end{array}$ & $\begin{array}{c}0.117 * \\
(1.91)\end{array}$ \\
\hline Observations & 900 & 900 & 90 & 90 & 90 & 90 & 90 & 90 & 90 & 90 & 90 & 90 \\
\hline Adj. R-Squared & 0.0565 & 0.0598 & 0.5711 & 0.1083 & 0.3157 & 0.1811 & 0.3530 & 0.3002 & 0.2898 & 0.3356 & 0.2313 & 0.2061 \\
\hline
\end{tabular}


Panel C: 60 percent volatility increase

\begin{tabular}{|c|c|c|c|c|c|c|c|c|c|c|c|c|}
\hline Variables & $\begin{array}{r}\text { Europea } \\
\text { Markets }\end{array}$ & $\begin{array}{r}\text { Europea } \\
\text { Markets }\end{array}$ & Athens & Brusse & Paris & Frankfurt & London & Madrid & Dublin & Milan & Stockholn & Zurich \\
\hline$G K e_{-} U S$ & $\begin{array}{c}0.582 * * \\
(2.41)\end{array}$ & $\begin{array}{c}0.419 * \\
(1.82)\end{array}$ & $\begin{array}{l}-0.010 \\
(-0.01)\end{array}$ & $\begin{array}{l}0.214 \\
(0.68)\end{array}$ & $\begin{array}{c}1.133 * * * \\
(3.74)\end{array}$ & $\begin{array}{c}0.731 * * \\
(2.33)\end{array}$ & $\begin{array}{c}0.688 * * * \\
(3.47)\end{array}$ & $\begin{array}{c}1.273 * * * \\
(3.73)\end{array}$ & $\begin{array}{l}-0.238 \\
(-0.72)\end{array}$ & $\begin{array}{l}0.830^{*} \\
(1.82)\end{array}$ & $\begin{array}{c}0.758 * * * \\
(3.26)\end{array}$ & $\begin{array}{l}0.438 \\
(1.60)\end{array}$ \\
\hline $1^{\mathrm{st}}$ minute & $\begin{array}{c}0.191 * * * \\
(5.65)\end{array}$ & $\begin{array}{c}0.151 * * * \\
(5.14)\end{array}$ & $\begin{array}{c}1.715 * * * \\
(9.24)\end{array}$ & $\begin{array}{c}0.111 * * \\
(2.50)\end{array}$ & $\begin{array}{l}-0.022 \\
(-0.53)\end{array}$ & $\begin{array}{l}0.053 \\
(1.21)\end{array}$ & $\begin{array}{l}0.008 \\
(0.30)\end{array}$ & $\begin{array}{l}-0.001 \\
(-0.02)\end{array}$ & $\begin{array}{l}0.043 \\
(0.92)\end{array}$ & $\begin{array}{l}-0.055 \\
(-0.86)\end{array}$ & $\begin{array}{l}0.027 \\
(0.83)\end{array}$ & $\begin{array}{l}0.028 \\
(0.73)\end{array}$ \\
\hline $2^{\text {nd }}$ minute & $\begin{array}{l}-0.004 \\
(-0.15)\end{array}$ & $\begin{array}{l}-0.023 \\
(-0.97)\end{array}$ & $\begin{array}{l}0.074 \\
(0.54)\end{array}$ & $\begin{array}{c}0.089 * * * \\
(2.76)\end{array}$ & $\begin{array}{l}-0.023 \\
(-0.73)\end{array}$ & $\begin{array}{l}-0.016 \\
(-0.49)\end{array}$ & $\begin{array}{c}-0.043 * * \\
(-2.14)\end{array}$ & $\begin{array}{l}-0.051 \\
(-1.46)\end{array}$ & $\begin{array}{c}0.084 * * \\
(2.48)\end{array}$ & $\begin{array}{c}-0.088^{*} \\
(-1.89)\end{array}$ & $\begin{array}{l}-0.020 \\
(-0.84)\end{array}$ & $\begin{array}{l}-0.044 \\
(-1.58)\end{array}$ \\
\hline $3^{\text {rd }}$ minute & $\begin{array}{c}0.068 * * \\
(2.58)\end{array}$ & $\begin{array}{c}0.071^{* * *} * \\
(2.69)\end{array}$ & $\begin{array}{c}0.957 * * * \\
(6.58)\end{array}$ & $\begin{array}{l}0.043 \\
(1.24)\end{array}$ & $\begin{array}{c}-0.084 * * \\
(-2.52)\end{array}$ & $\begin{array}{l}-0.017 \\
(-0.49)\end{array}$ & $\begin{array}{c}-0.065 * * * \\
(-2.99)\end{array}$ & $\begin{array}{l}-0.055 \\
(-1.47)\end{array}$ & $\begin{array}{l}-0.031 \\
(-0.85)\end{array}$ & $\begin{array}{l}-0.019 \\
(-0.39)\end{array}$ & $\begin{array}{l}-0.022 \\
(-0.86)\end{array}$ & $\begin{array}{l}-0.025 \\
(-0.84)\end{array}$ \\
\hline $4^{\text {th }}$ minute & $\begin{array}{c}-0.078 * * * \\
(-3.14)\end{array}$ & $\begin{array}{c}-0.064 * * * \\
(-2.99)\end{array}$ & $\begin{array}{c}-0.611 * * * \\
(-4.47)\end{array}$ & $\begin{array}{l}-0.041 \\
(-1.26)\end{array}$ & $\begin{array}{l}-0.039 \\
(-1.25)\end{array}$ & $\begin{array}{l}-0.044 \\
(-1.35)\end{array}$ & $\begin{array}{l}-0.027 \\
(-1.34)\end{array}$ & $\begin{array}{c}-0.067^{*} \\
(-1.92)\end{array}$ & $\begin{array}{l}-0.047 \\
(-1.38)\end{array}$ & $\begin{array}{l}0.166 \\
(3.53)\end{array}$ & $\begin{array}{l}-0.028 \\
(-1.15)\end{array}$ & $\begin{array}{l}-0.042 \\
(-1.49)\end{array}$ \\
\hline 60 percent & $\begin{array}{c}0.094 * * * \\
(4.67)\end{array}$ & $\begin{array}{c}0.083 * * * \\
(4.20)\end{array}$ & $\begin{array}{c}0.731 * * * \\
(6.61)\end{array}$ & $\begin{array}{c}0.055^{* *} * \\
(2.09))\end{array}$ & $\begin{array}{c}0.051 * * \\
(2.02)\end{array}$ & $\begin{array}{l}0.034 \\
(1.31)\end{array}$ & $\begin{array}{l}0.010 \\
(0.58)\end{array}$ & $\begin{array}{l}0.040 \\
(1.41)\end{array}$ & $\begin{array}{l}-0.019 \\
(-0.69)\end{array}$ & $\begin{array}{l}-0.022 \\
(-0.58)\end{array}$ & $\begin{array}{c}0.045 * * \\
(2.31)\end{array}$ & $\begin{array}{l}0.013 \\
(0.59)\end{array}$ \\
\hline Healthcare & $\begin{array}{c}0.068 * * \\
(2.57)\end{array}$ & --- & $\begin{array}{c}0.887 * * * \\
(6.06)\end{array}$ & $\begin{array}{l}0.052 \\
(1.49)\end{array}$ & $\begin{array}{l}-0.012 \\
(-0.36)\end{array}$ & $\begin{array}{l}-0.049 \\
(-1.41)\end{array}$ & $\begin{array}{l}0.001 \\
(0.06)\end{array}$ & $\begin{array}{l}-0.040 \\
(-1.07)\end{array}$ & $\begin{array}{l}-0.021 \\
(-0.58)\end{array}$ & $\begin{array}{l}-0.070 \\
(-1.40)\end{array}$ & $\begin{array}{l}-0.012 \\
(-0.48)\end{array}$ & $\begin{array}{c}-0.052 * \\
(-1.72)\end{array}$ \\
\hline Industrials & $\begin{array}{l}0.017 \\
(0.62)\end{array}$ & --- & $\begin{array}{c}0.498 * * * \\
(3.35)\end{array}$ & $\begin{array}{c}0.090 * * \\
(2.55)\end{array}$ & $\begin{array}{c}-0.076 * * \\
(-2.24)\end{array}$ & $\begin{array}{l}-0.030 \\
(-0.85)\end{array}$ & $\begin{array}{l}-0.005 \\
(-0.21)\end{array}$ & $\begin{array}{l}-0.060 \\
(-1.56)\end{array}$ & $\begin{array}{l}0.009 \\
(0.24)\end{array}$ & $\begin{array}{c}-0.191 * * * \\
(-3.75)\end{array}$ & $\begin{array}{l}-0.005 \\
(-0.20)\end{array}$ & $\begin{array}{c}-0.065 * * \\
(-2.11)\end{array}$ \\
\hline Currency 1 & --- & $\begin{array}{c}0.062 * * \\
(2.06)\end{array}$ & --- & --- & --- & --- & --- & --- & --- & --- & --- & --- \\
\hline Currency 2 & --- & $\begin{array}{l}0.008 \\
(0.24)\end{array}$ & --- & --- & --- & --- & --- & --- & --- & --- & --- & --- \\
\hline Constant & $\begin{array}{c}-0.116 * * \\
(-2.36)\end{array}$ & $\begin{array}{l}-0.085 \\
(-1.78)\end{array}$ & $\begin{array}{c}-1.837 * * * \\
(-6.77)\end{array}$ & $\begin{array}{l}-0.084 \\
(-1.31)\end{array}$ & $\begin{array}{c}0.135^{* *} \\
(2.18)\end{array}$ & $\begin{array}{l}0.079 \\
(1.23)\end{array}$ & $\begin{array}{l}0.063 \\
(1.55)\end{array}$ & $\begin{array}{l}0.104 \\
(1.49)\end{array}$ & $\begin{array}{l}0.053 \\
(0.79)\end{array}$ & $\begin{array}{c}0.190 * * \\
(2.04)\end{array}$ & $\begin{array}{l}0.026 \\
(0.55)\end{array}$ & $\begin{array}{l}0.108^{*} \\
(1.92)\end{array}$ \\
\hline Observations & 900 & 900 & 90 & 90 & 90 & 90 & 90 & 90 & 90 & 90 & 90 & 90 \\
\hline Adj. R-Squared & 0.0565 & 0.0621 & 0.6578 & 0.1836 & 0.3276 & 0.1947 & 0.3510 & 0.3129 & 0.1898 & 0.2953 & 0.2695 & 0.2094 \\
\hline
\end{tabular}




\section{Appendix D: Volatility Spillover effect in European Equity markets}

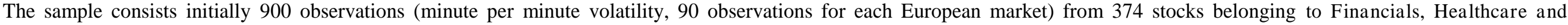

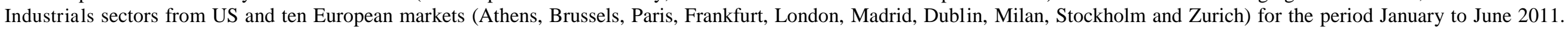
The following regression is estimated:

$$
G K e_{m, i, t+1}=\alpha+\beta_{1} G K e_{-} U S_{i, t}+\beta_{2} G K e_{-} U S_{i, t-1}+\beta_{2} G K e_{-} U S_{i, t-2}+\beta_{2} G K e_{-} U S_{i, t-3}+\beta_{2} G K e_{-} U S_{i, t-4}+\sum_{k=1}^{L} \beta_{2, k}\left(G K e_{-} U S_{i, t} \times D_{m, k, t}\right)+\varepsilon_{m, i, t}
$$

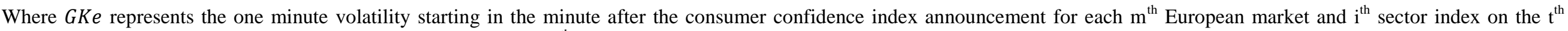

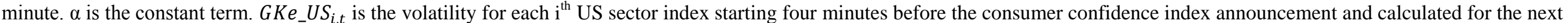

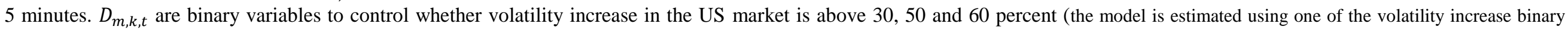
variables at a time). $\varepsilon_{m, i, t}$ is the error term. $* * *, * * *$ and denotes significance at the $1 \%, 5 \%$, and $10 \%$ level, respectively. T-statistics are reported in parenthesis.

\section{Panel C: 30 percent volatility increase}

\begin{tabular}{|c|c|c|c|c|c|c|c|c|c|c|c|}
\hline Variables & $\begin{array}{c}\text { European } \\
\text { Markets }\end{array}$ & Athens & Brussels & Paris & Frankfurt & London & Madrid & Dublin & Milan & Stockholm & Zurich \\
\hline$G K e_{-} U S_{t}$ & $\begin{array}{c}0.512^{*} \\
(1.74)\end{array}$ & $\begin{array}{l}-1.463 \\
(-0.57)\end{array}$ & $\begin{array}{l}0.230 \\
(0.57)\end{array}$ & $\begin{array}{c}0.984 * * \\
(2.63)\end{array}$ & $\begin{array}{c}0.929 * * \\
(2.50)\end{array}$ & $\begin{array}{c}0.948 * * * \\
(3.90)\end{array}$ & $\begin{array}{l}1.442 \\
(3.48)\end{array}$ & $\begin{array}{l}-0.089 \\
(-0.23)\end{array}$ & $\begin{array}{l}0.858 \\
(1.44)\end{array}$ & $\begin{array}{c}0.944 * * * \\
(3.48)\end{array}$ & $\begin{array}{l}0.308 \\
(0.87)\end{array}$ \\
\hline$G K e_{-} U S_{t-1}$ & $\begin{array}{l}-0.494 \\
(-1.61)\end{array}$ & $\begin{array}{l}-0.568 \\
(-0.21)\end{array}$ & $\begin{array}{l}-0.155 \\
(-0.37)\end{array}$ & $\begin{array}{l}-0.506 \\
(-1.30)\end{array}$ & $\begin{array}{l}-0.824 * \\
(-2.13)\end{array}$ & $\begin{array}{l}-0.416 \\
(-1.65)\end{array}$ & $\begin{array}{c}-0.960 * * \\
(-2.23)\end{array}$ & $\begin{array}{c}-.3124351 \\
(-0.77)\end{array}$ & $\begin{array}{l}-0.663 \\
(-1.07)\end{array}$ & $\begin{array}{l}-0.434 \\
(-1.54)\end{array}$ & $\begin{array}{l}-0.072 \\
(-0.20)\end{array}$ \\
\hline$G K e_{-} U S_{t-2}$ & $\begin{array}{l}-0.055 \\
(-0.17)\end{array}$ & $\begin{array}{l}-1.546 \\
(-0.56)\end{array}$ & $\begin{array}{l}-0.158 \\
(-0.36)\end{array}$ & $\begin{array}{l}0.213 \\
(0.52)\end{array}$ & $\begin{array}{l}0.396 \\
(0.97)\end{array}$ & $\begin{array}{l}0.183 \\
(0.69)\end{array}$ & $\begin{array}{l}0.602 \\
(1.33)\end{array}$ & $\begin{array}{c}-.2675018 \\
(-0.62)\end{array}$ & $\begin{array}{l}0.243 \\
(0.37)\end{array}$ & $\begin{array}{l}-0.072 \\
(-0.24)\end{array}$ & $\begin{array}{l}-0.116 \\
(-0.30)\end{array}$ \\
\hline$G K e_{-} U S_{t-3}$ & $\begin{array}{l}-0.188 \\
(-0.57)\end{array}$ & $\begin{array}{l}0.869 \\
(0.30)\end{array}$ & $\begin{array}{l}-0.074 \\
(-0.16)\end{array}$ & $\begin{array}{l}-0.689 \\
(-1.64)\end{array}$ & $\begin{array}{l}-0.591 \\
(-1.41)\end{array}$ & $\begin{array}{l}-0.347 \\
(-1.27)\end{array}$ & $\begin{array}{l}-0.704 \\
(-1.51)\end{array}$ & $\begin{array}{l}-0.494 \\
(-1.12)\end{array}$ & $\begin{array}{l}0.355 \\
(0.53)\end{array}$ & $\begin{array}{l}-0.083 \\
(-0.27)\end{array}$ & $\begin{array}{l}-0.115 \\
(-0.29)\end{array}$ \\
\hline$G K e_{-} U S_{t-4}$ & $\begin{array}{l}-0.145 \\
(-0.36)\end{array}$ & $\begin{array}{l}-5.380 \\
(-1.53)\end{array}$ & $\begin{array}{l}-0.127 \\
(-0.23)\end{array}$ & $\begin{array}{c}1.228 * * \\
(2.39)\end{array}$ & $\begin{array}{l}0.889^{*} \\
(1.74)\end{array}$ & $\begin{array}{c}0.725^{* *} \\
(2.17)\end{array}$ & $\begin{array}{l}0.723 \\
(1.27)\end{array}$ & $\begin{array}{l}-0.250 \\
(-0.46)\end{array}$ & $\begin{array}{l}-0.234 \\
(-0.28)\end{array}$ & $\begin{array}{c}0.713 * * \\
(1.91)\end{array}$ & $\begin{array}{l}0.248 \\
(0.51)\end{array}$ \\
\hline$G K e_{-} U S_{t \times} 30$ percent & $\begin{array}{l}0.210 \\
(0.95)\end{array}$ & $\begin{array}{l}0.433 \\
(0.23)\end{array}$ & $\begin{array}{l}-0.151 \\
(-0.49)\end{array}$ & $\begin{array}{l}0.372 \\
(1.32)\end{array}$ & $\begin{array}{l}0.211 \\
(0.75)\end{array}$ & $\begin{array}{l}0.063 \\
(0.34)\end{array}$ & $\begin{array}{l}0.455 \\
(1.46)\end{array}$ & $\begin{array}{l}-0.540^{*} \\
(-1.83)\end{array}$ & $\begin{array}{c}0.924 * * \\
(2.05)\end{array}$ & $\begin{array}{l}0.142 \\
(0.69)\end{array}$ & $\begin{array}{l}0.211 \\
(0.79)\end{array}$ \\
\hline Constant & $\begin{array}{l}0.210 \\
(0.95)\end{array}$ & $\begin{array}{c}0.835 * * * \\
(3.67)\end{array}$ & $\begin{array}{c}0.134 * * * \\
(3.67)\end{array}$ & $\begin{array}{l}0.057^{*} \\
(1.71)\end{array}$ & $\begin{array}{c}0.081 * * \\
(2.44)\end{array}$ & $\begin{array}{l}0.0135 \\
(0.62)\end{array}$ & $\begin{array}{l}0.032 \\
(0.86)\end{array}$ & $\begin{array}{c}0.182 * * * \\
(5.20)\end{array}$ & $\begin{array}{l}0.057 \\
(1.07)\end{array}$ & $\begin{array}{l}0.021 \\
(0.85)\end{array}$ & $\begin{array}{c}0.072 * * \\
(2.27)\end{array}$ \\
\hline $\begin{array}{l}\text { Observations } \\
\text { Adj. R-Squared }\end{array}$ & $\begin{array}{c}900 \\
0.0138\end{array}$ & $\begin{array}{c}90 \\
0.0760\end{array}$ & $\begin{array}{c}90 \\
0.0200\end{array}$ & $\begin{array}{c}90 \\
0.2554\end{array}$ & $\begin{array}{c}90 \\
0.1778\end{array}$ & $\begin{array}{c}90 \\
0.2939\end{array}$ & $\begin{array}{c}90 \\
0.2677\end{array}$ & $\begin{array}{c}90 \\
0.1811\end{array}$ & $\begin{array}{c}90 \\
0.1208\end{array}$ & $\begin{array}{c}90 \\
0.2814\end{array}$ & $\begin{array}{c}90 \\
0.0508\end{array}$ \\
\hline
\end{tabular}


Panel C: 50 percent volatility increase

\begin{tabular}{|c|c|c|c|c|c|c|c|c|c|c|c|}
\hline Variables & $\begin{array}{c}\text { European } \\
\text { Markets }\end{array}$ & Athens & Brussels & Paris & Frankfurt & London & Madrid & Dublin & Milan & Stockholm & Zurich \\
\hline$G K e_{-} U S_{t}$ & $\begin{array}{l}0.428 \\
(1.46)\end{array}$ & $\begin{array}{l}-2.28 \\
(-0.89)\end{array}$ & $\begin{array}{l}0.095 \\
(0.23)\end{array}$ & $\begin{array}{c}0.935^{* *} \\
(2.51)\end{array}$ & $\begin{array}{c}1.102 * * * \\
(2.95)\end{array}$ & $\begin{array}{c}1.008 * * * \\
(4.14)\end{array}$ & $\begin{array}{l}1.531 * * * \\
(3.67)\end{array}$ & $\begin{array}{l}-0.383 \\
(-0.96)\end{array}$ & $\begin{array}{l}0.860 \\
(1.44)\end{array}$ & $\begin{array}{l}0.962 * * * \\
(3.54)\end{array}$ & $\begin{array}{l}0.409 \\
(1.15)\end{array}$ \\
\hline$G K e_{-} U S_{t-1}$ & $\begin{array}{l}-0.503 \\
(-1.60)\end{array}$ & $\begin{array}{l}-0.602 \\
(-0.23)\end{array}$ & $\begin{array}{l}-0.160 \\
(-0.38)\end{array}$ & $\begin{array}{l}-0.517 \\
(-1.34)\end{array}$ & $\begin{array}{c}-0.819 * * \\
(-2.11)\end{array}$ & $\begin{array}{l}-0.414 \\
(-1.64)\end{array}$ & $\begin{array}{c}-0.965 * * \\
(-2.22)\end{array}$ & $\begin{array}{l}-0.318 \\
(-0.76)\end{array}$ & $\begin{array}{l}-0.685 \\
(-1.10)\end{array}$ & $\begin{array}{l}-0.436 \\
(-1.54)\end{array}$ & $\begin{array}{l}-0.071 \\
(-0.19)\end{array}$ \\
\hline$G K e_{-} U S_{t-2}$ & $\begin{array}{l}-0.057 \\
(-0.18)\end{array}$ & $\begin{array}{l}-1.503 \\
(-0.54)\end{array}$ & $\begin{array}{l}-0.134 \\
(-0.30)\end{array}$ & $\begin{array}{l}0.199 \\
(0.49)\end{array}$ & $\begin{array}{l}0.365 \\
(0.90)\end{array}$ & $\begin{array}{l}0.173 \\
(0.65)\end{array}$ & $\begin{array}{l}0.567 \\
(1.25)\end{array}$ & $\begin{array}{l}-0.204 \\
(-0.47)\end{array}$ & $\begin{array}{c}0.193 \\
(0.30)\end{array}$ & $\begin{array}{l}-0.082 \\
(-0.28)\end{array}$ & $\begin{array}{l}-0.139 \\
(-0.36)\end{array}$ \\
\hline$G K e_{-} U S_{t-3}$ & $\begin{array}{l}-0.203 \\
(-0.62)\end{array}$ & $\begin{array}{l}0.816 \\
(0.28)\end{array}$ & $\begin{array}{l}-0.068 \\
(-0.15)\end{array}$ & $\begin{array}{c}-0.714 * \\
(-1.71)\end{array}$ & $\begin{array}{l}-0.600 \\
(-1.43)\end{array}$ & $\begin{array}{l}-0.350 \\
(-1.28)\end{array}$ & $\begin{array}{l}-0.731 \\
(-1.56)\end{array}$ & $\begin{array}{l}-0.468 \\
(-1.04)\end{array}$ & $\begin{array}{l}0.295 \\
(0.44)\end{array}$ & $\begin{array}{l}-0.091 \\
(-0.30)\end{array}$ & $\begin{array}{l}-0.126 \\
(-0.32)\end{array}$ \\
\hline$G K e_{-} U S_{t-4}$ & $\begin{array}{l}-0.192 \\
(-0.48)\end{array}$ & $\begin{array}{l}-5.705 \\
(-1.63)\end{array}$ & $\begin{array}{l}-0.171 \\
(-0.31)\end{array}$ & $\begin{array}{c}1.183^{* * *} \\
(2.30)\end{array}$ & $\begin{array}{l}0.945^{*} \\
(1.84)\end{array}$ & $\begin{array}{c}0.745^{* *} \\
(2.22)\end{array}$ & $\begin{array}{l}0.729 \\
(1.27)\end{array}$ & $\begin{array}{l}-0.333 \\
(-0.60)\end{array}$ & $\begin{array}{l}-0.295 \\
(-0.36)\end{array}$ & $\begin{array}{l}0.711^{*} \\
(1.90)\end{array}$ & $\begin{array}{l}0.275 \\
(0.56)\end{array}$ \\
\hline$G K e_{-} U S_{t \times} 50$ percent & $\begin{array}{l}0.339^{*} \\
(1.65)\end{array}$ & $\begin{array}{l}1.763 \\
(0.98)\end{array}$ & $\begin{array}{l}0.094 \\
(0.33)\end{array}$ & $\begin{array}{c}0.433^{*} \\
(1.65)\end{array}$ & $\begin{array}{l}-0.106 \\
(-0.40)\end{array}$ & $\begin{array}{c}-0.0456 \\
(-0.27)\end{array}$ & $\begin{array}{l}0.268 \\
(0.91)\end{array}$ & $\begin{array}{l}0.009 \\
(0.03)\end{array}$ & $\begin{array}{c}0.859 * * \\
(2.03)\end{array}$ & $\begin{array}{l}0.101 \\
(0.53)\end{array}$ & $\begin{array}{l}0.021 \\
(0.08)\end{array}$ \\
\hline Constant & $\begin{array}{c}0.157 * * * \\
(6.00)\end{array}$ & $\begin{array}{c}0.869 * * * \\
(3.84)\end{array}$ & $\begin{array}{c}0.132 * * * \\
(3.65)\end{array}$ & $\begin{array}{c}0.069^{* *} \\
(2.09)\end{array}$ & $\begin{array}{c}0.083^{* *} \\
(2.51)\end{array}$ & $\begin{array}{c}0.0140 \\
(0.64)\end{array}$ & $\begin{array}{l}0.043 \\
(1.16)\end{array}$ & $\begin{array}{c}0.173^{* * * *} \\
(4.87)\end{array}$ & $\begin{array}{l}0.085 \\
(1.59)\end{array}$ & $\begin{array}{l}0.024 \\
(1.01)\end{array}$ & $\begin{array}{c}0.075^{* *} \\
(2.39)\end{array}$ \\
\hline $\begin{array}{l}\text { Observations } \\
\text { Adj. R-Squared }\end{array}$ & $\begin{array}{c}900 \\
0.0157\end{array}$ & $\begin{array}{c}90 \\
0.0861\end{array}$ & $\begin{array}{c}90 \\
0.0184\end{array}$ & $\begin{array}{c}90 \\
0.2638\end{array}$ & $\begin{array}{c}90 \\
0.1738\end{array}$ & $\begin{array}{c}90 \\
0.2935\end{array}$ & $\begin{array}{c}90 \\
0.2564\end{array}$ & $\begin{array}{c}90 \\
0.1481\end{array}$ & $\begin{array}{c}90 \\
0.1200\end{array}$ & $\begin{array}{c}90 \\
0.2796\end{array}$ & $\begin{array}{c}90 \\
0.0437\end{array}$ \\
\hline
\end{tabular}


Panel C: 60 percent volatility increase

\begin{tabular}{|c|c|c|c|c|c|c|c|c|c|c|c|}
\hline Variables & $\begin{array}{c}\text { European } \\
\text { Markets }\end{array}$ & Athens & Brussels & Paris & Frankfurt & London & Madrid & Dublin & Milan & Stockholm & Zurich \\
\hline$G K e_{-} U S_{t}$ & $\begin{array}{l}0.248 \\
(0.83)\end{array}$ & $\begin{array}{l}-3.832 \\
(-1.50)\end{array}$ & $\begin{array}{l}-0.153 \\
(-0.37)\end{array}$ & $\begin{array}{c}0.851 * * \\
(2.25)\end{array}$ & $\begin{array}{c}0.9360 * * \\
(2.45)\end{array}$ & $\begin{array}{c}1.036 * * * \\
(4.17)\end{array}$ & $\begin{array}{c}1.402 * * * \\
(3.31)\end{array}$ & $\begin{array}{l}-0.347 \\
(-0.85)\end{array}$ & $\begin{array}{c}1.358 * * \\
(2.17)\end{array}$ & $\begin{array}{c}0.809 * * * \\
(2.95)\end{array}$ & $\begin{array}{l}0.329 \\
(0.91)\end{array}$ \\
\hline$G K e_{-} U S_{t-1}$ & $\begin{array}{c}-0.531^{*} \\
(-1.74)\end{array}$ & $\begin{array}{l}-0.773 \\
(-0.30)\end{array}$ & $\begin{array}{l}-0.189 \\
(-0.45)\end{array}$ & $\begin{array}{l}-0.538 \\
(-1.40)\end{array}$ & $\begin{array}{c}-0.834 * * \\
(-2.15)\end{array}$ & $\begin{array}{l}-0.410 \\
(-1.62)\end{array}$ & $\begin{array}{c}-0.986^{* *} \\
(-2.29)\end{array}$ & $\begin{array}{l}-0.314 \\
(-0.75)\end{array}$ & $\begin{array}{l}-0.654 \\
(-1.03)\end{array}$ & $\begin{array}{l}-0.455 \\
(-1.63)\end{array}$ & $\begin{array}{l}-0.080 \\
(-0.22)\end{array}$ \\
\hline$G K e_{-} U S_{t-2}$ & $\begin{array}{l}-0.079 \\
(-0.25)\end{array}$ & $\begin{array}{l}-1.650 \\
(-0.61)\end{array}$ & $\begin{array}{l}-0.140 \\
(-0.32)\end{array}$ & $\begin{array}{c}.171131 \\
(0.42)\end{array}$ & $\begin{array}{l}0.372 \\
(0.92)\end{array}$ & $\begin{array}{l}0.175 \\
(0.66)\end{array}$ & $\begin{array}{l}0.550 \\
(1.22)\end{array}$ & $\begin{array}{l}-0.205 \\
(-0.47)\end{array}$ & $\begin{array}{l}0.135 \\
(0.20)\end{array}$ & $\begin{array}{l}-0.088 \\
(-0.30)\end{array}$ & $\begin{array}{l}-0.140 \\
(-0.36)\end{array}$ \\
\hline$G K e_{-} U S_{t-3}$ & $\begin{array}{c}-.2356843 \\
(-0.72)\end{array}$ & $\begin{array}{l}0.586 \\
(0.21)\end{array}$ & $\begin{array}{l}-0.097 \\
(-0.22)\end{array}$ & $\begin{array}{c}-0.741 * \\
(-1.78)\end{array}$ & $\begin{array}{l}-0.613 \\
(-1.46)\end{array}$ & $\begin{array}{l}-0.345 \\
(-1.26)\end{array}$ & $\begin{array}{l}-0.755 \\
(-1.62)\end{array}$ & $\begin{array}{l}-0.464 \\
(-1.03)\end{array}$ & $\begin{array}{c}.3090683 \\
(0.45)\end{array}$ & $\begin{array}{l}-0.111 \\
(-0.37)\end{array}$ & $\begin{array}{l}-0.135 \\
(-0.34)\end{array}$ \\
\hline$G K e_{-} U S_{t-4}$ & $\begin{array}{l}-0.271 \\
(-0.67)\end{array}$ & $\begin{array}{c}-6.319 * * * \\
(-1.84)\end{array}$ & $\begin{array}{l}-0.277 \\
(-0.50)\end{array}$ & $\begin{array}{c}1.143 * * \\
(2.23)\end{array}$ & $\begin{array}{c}0.876^{*} \\
(1.70)\end{array}$ & $\begin{array}{r}0.758 * * \\
(2.25)\end{array}$ & $\begin{array}{l}0.672 \\
(1.17)\end{array}$ & $\begin{array}{l}-0.318 \\
(-0.58)\end{array}$ & $\begin{array}{l}-0.092 \\
(-0.11)\end{array}$ & $\begin{array}{c}0.645^{*} \\
(1.74)\end{array}$ & $\begin{array}{l}0.241 \\
(0.49)\end{array}$ \\
\hline$G K e_{-} U S_{t \times} 60$ percent & $\begin{array}{c}0.595 * * * \\
(2.79)\end{array}$ & $\begin{array}{c}3.969 * * \\
(2.20)\end{array}$ & $\begin{array}{l}0.482^{*} \\
(1.65)\end{array}$ & $\begin{array}{c}0.528 * * \\
(1.96)\end{array}$ & $\begin{array}{l}0.168 \\
(0.62)\end{array}$ & $\begin{array}{l}-0.086 \\
(-0.49)\end{array}$ & $\begin{array}{l}0.450 \\
(1.49)\end{array}$ & $\begin{array}{l}-0.049 \\
(-0.17)\end{array}$ & $\begin{array}{l}-0.011 \\
(-0.02)\end{array}$ & $\begin{array}{l}0.337^{*} \\
(1.73)\end{array}$ & $\begin{array}{l}0.146 \\
(0.56)\end{array}$ \\
\hline Constant & $\begin{array}{c}0.176 * * * \\
(6.45)\end{array}$ & $\begin{array}{c}1.005 * * * \\
(4.34)\end{array}$ & $\begin{array}{l}0.150 \\
(4.02)\end{array}$ & $\begin{array}{c}0.084 * * \\
(2.45)\end{array}$ & $\begin{array}{c}0.091 * * \\
(2.63)\end{array}$ & $\begin{array}{c}.0111203 \\
(0.49)\end{array}$ & $\begin{array}{l}0.057 \\
(1.49)\end{array}$ & $\begin{array}{c}0.171 * * * \\
(4.60)\end{array}$ & $\begin{array}{l}0.072 \\
(1.27)\end{array}$ & $\begin{array}{l}0.036 \\
(1.46)\end{array}$ & $\begin{array}{c}0.081^{* *} \\
(2.46)\end{array}$ \\
\hline $\begin{array}{l}\text { Observations } \\
\text { Adj. R-Squared }\end{array}$ & $\begin{array}{c}900 \\
0.0213\end{array}$ & $\begin{array}{c}90 \\
0.1261\end{array}$ & $\begin{array}{c}90 \\
0.0482\end{array}$ & $\begin{array}{c}90 \\
0.2733\end{array}$ & $\begin{array}{c}90 \\
0.1760\end{array}$ & $\begin{array}{c}90 \\
0.2949\end{array}$ & $\begin{array}{c}90 \\
0.2686\end{array}$ & $\begin{array}{c}90 \\
0.1484\end{array}$ & $\begin{array}{c}90 \\
0.0763\end{array}$ & $\begin{array}{c}90 \\
0.3023\end{array}$ & $\begin{array}{c}90 \\
0.0473\end{array}$ \\
\hline
\end{tabular}

